Doktori (Ph.D) értekezés

\title{
MIKRO- ÉS MEZOPÓRUSOS KATALIZÁTOROK ALKALMAZÁSA GLICERIN REAKTÍV DESZTILLÁCIÓJÁBAN
}

\author{
Mészáros Szilvia \\ okleveles környezetkutató
}

Témavezetők:

Dr. Halász János

Dr. Pálinkó István

Környezettudományi Doktori Iskola

Alkalmazott és Környezeti Kémiai Tanszék

Szerves Kémiai Tanszék

Természettudományi és Informatikai Kar

Szegedi Tudományegyetem

Szeged 


\section{Tartalomjegyzék}

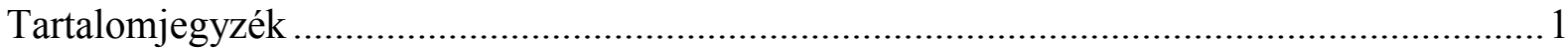

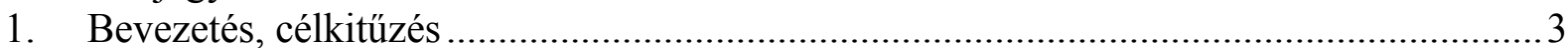

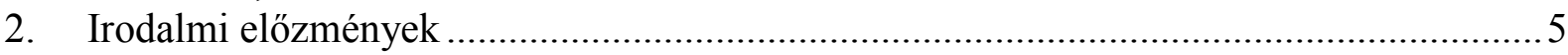

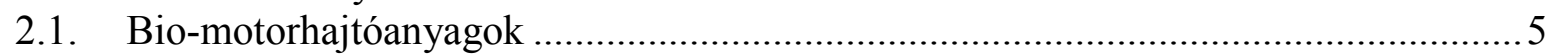

2.2. A biodízel technológiai, gazdasági és társadalmi kérdései ...................................... 6

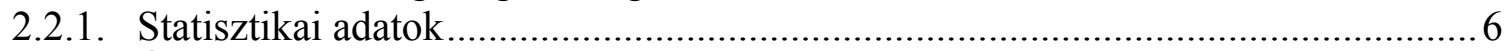

2.2.2. Érvek, ellenérvek a bioüzemanyagokról ................................................... 7

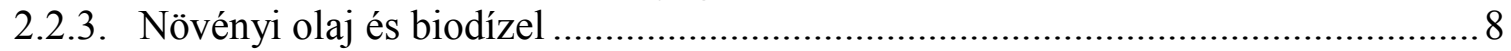

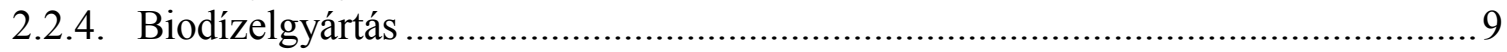

2.3. A melléktermék glicerin felhasználási és átalakítási lehetőségei .............................. 10

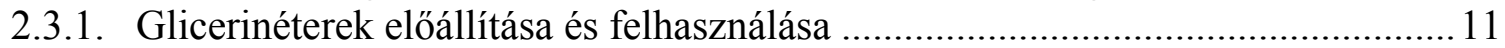

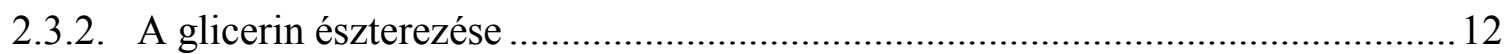

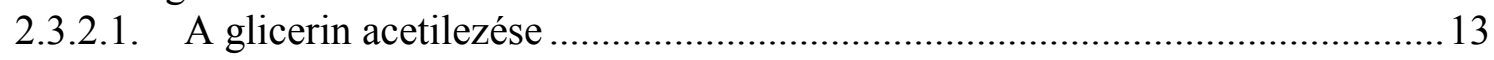

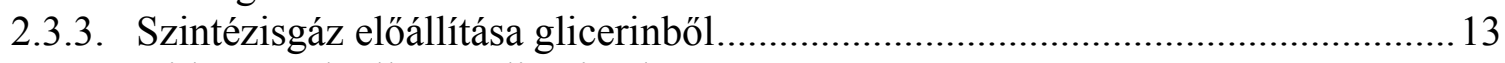

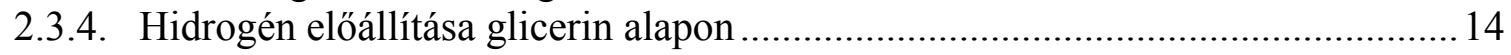

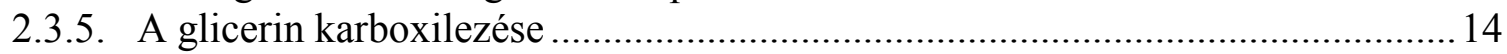

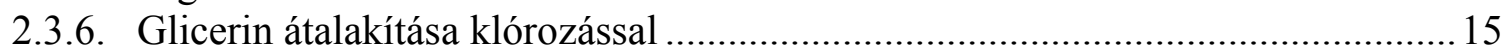

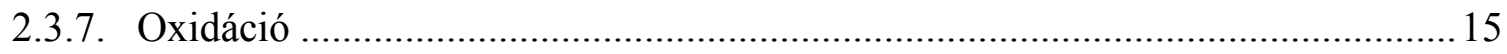

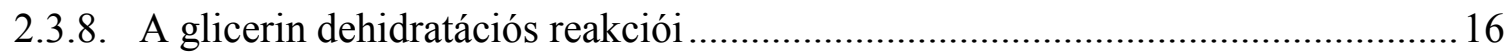

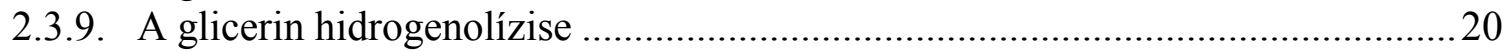

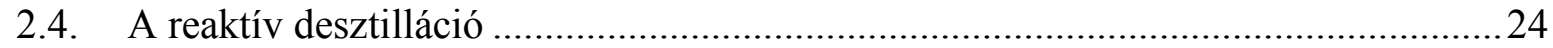

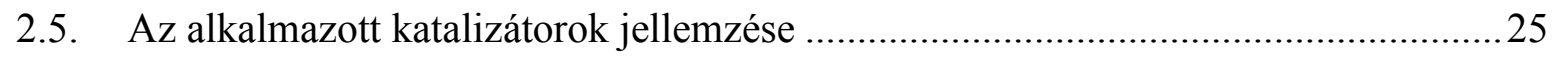

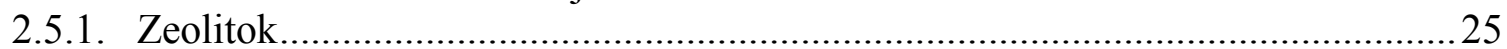

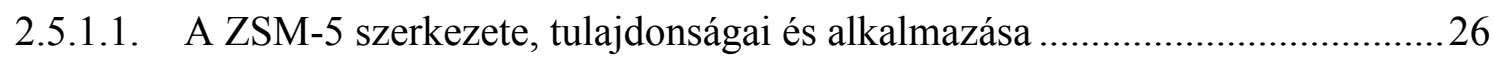

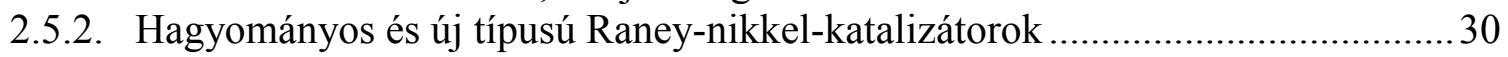

2.5.2.1. A hagyományos Raney-nikkel, tulajdonságai, előállítása és alkalmazása ..... 30

2.5.2.2. Az új típusú Raney-nikkel, tulajdonságai és előállítása.................................. 31

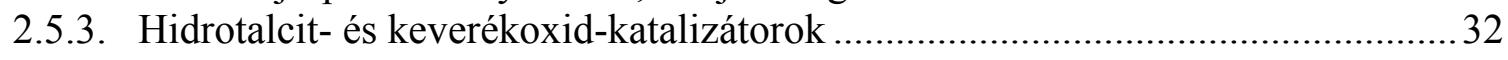

2.5.3.1. Réteges szerkezetek csoportosítása, a hidrotalcitok története .......................... 32

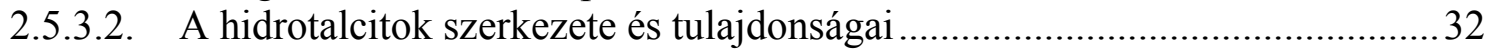

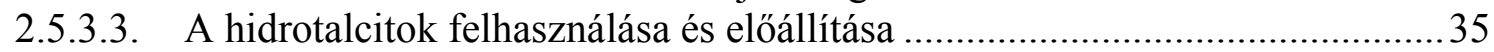

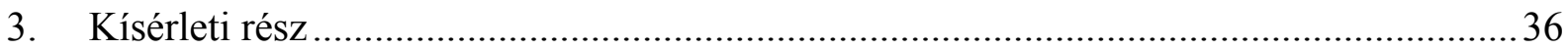

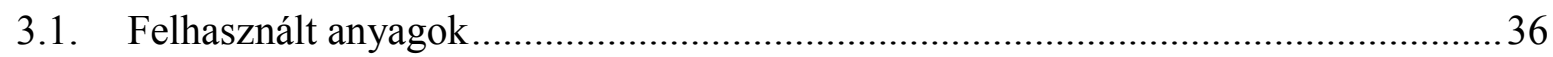

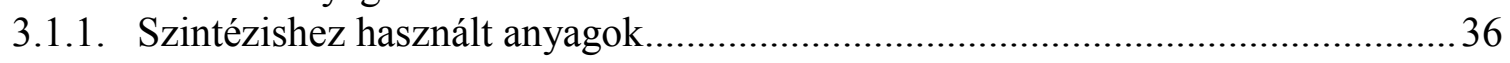

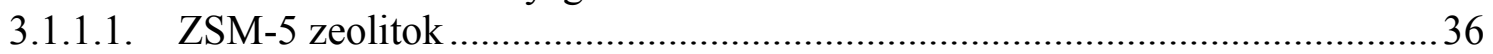

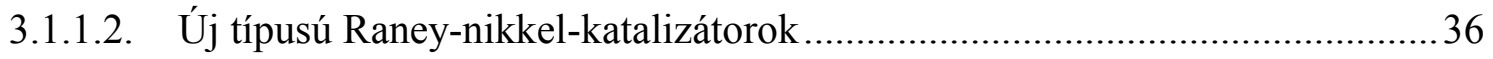

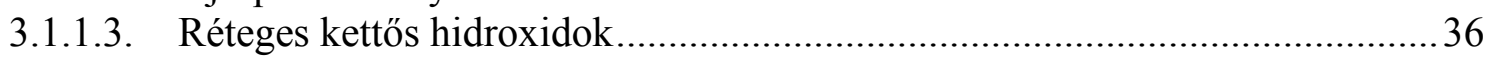

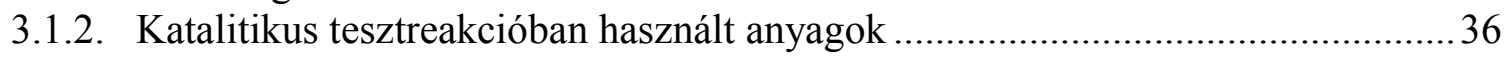

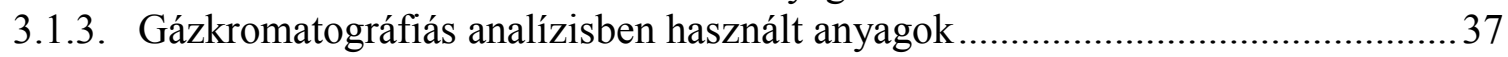

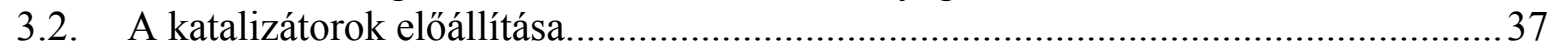

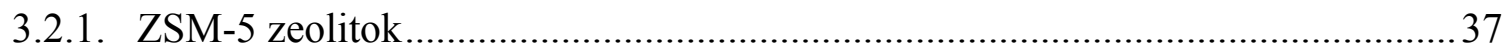

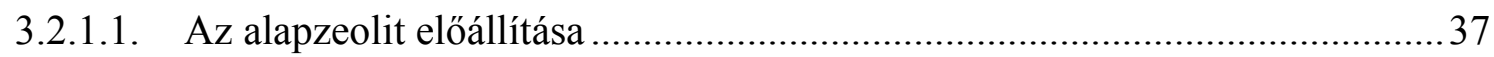

3.2.1.2. Ti-ZSM-5 előállítása izomorf szubsztitúcióval ............................................. 38

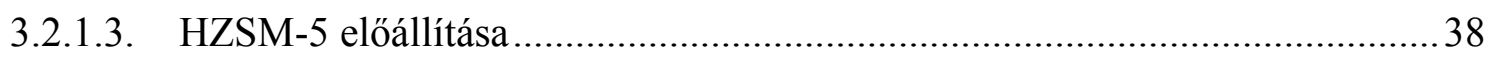

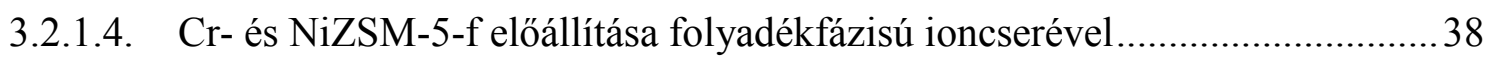

3.2.1.5. Cu- és NiZSM-5-sz előállítása szilárdfázisú ioncserével ................................39

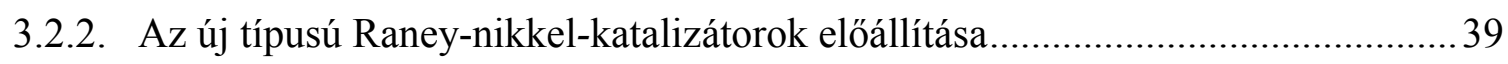

3.2.3. Hidrotalcit- és keverékoxid-katalizátorok előállítása ........................................ 40 


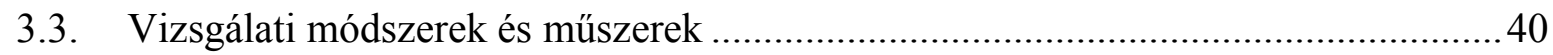

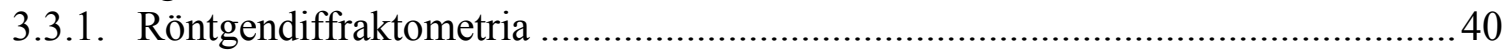

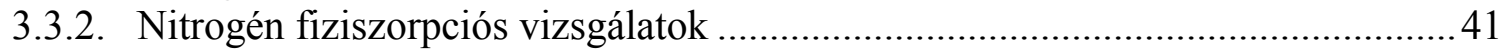

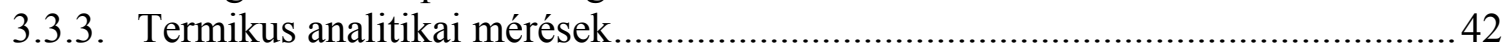

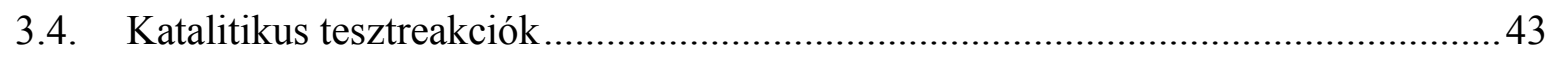

3.4.1. Kísérleti berendezés és a mérés körülményei .................................................. 43

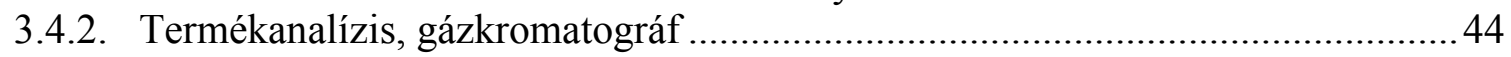

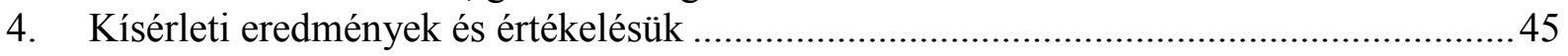

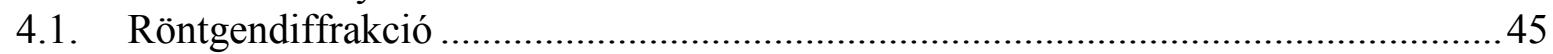

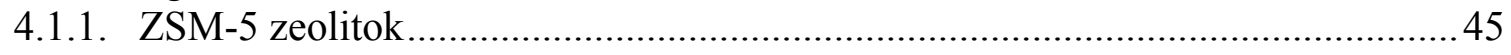

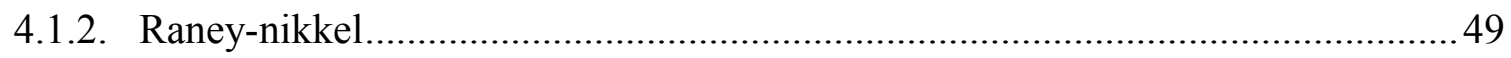

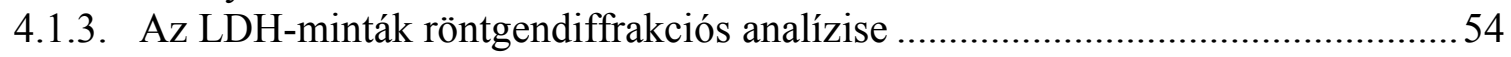

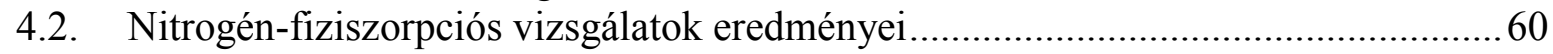

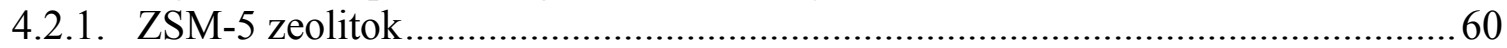

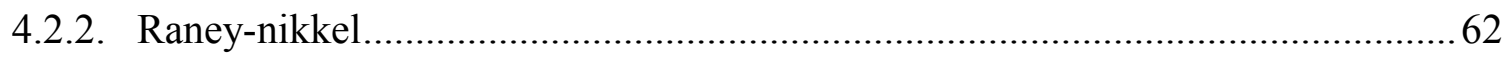

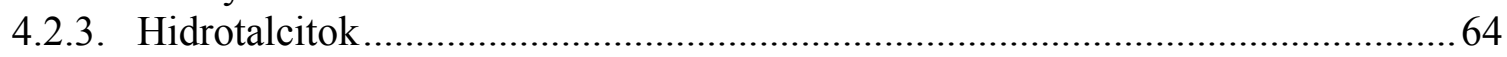

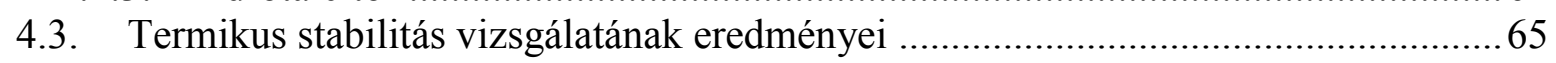

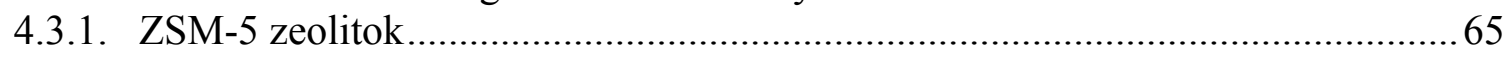

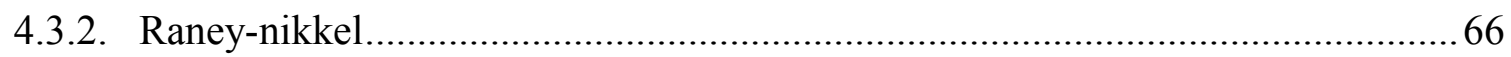

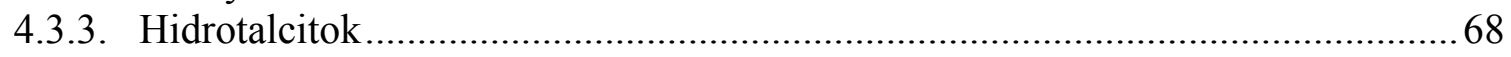

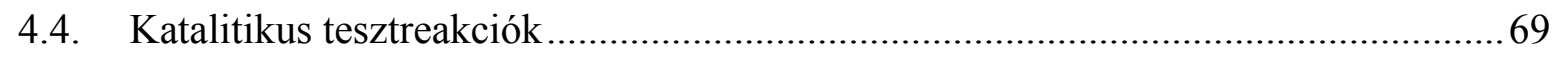

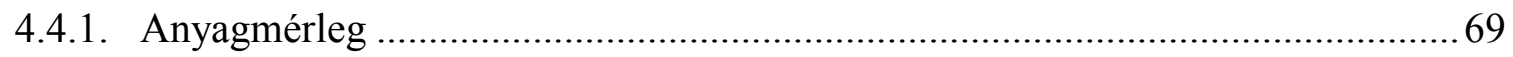

4.4.2. A különböző paraméterek változása a reaktív desztilláció közben ......................69

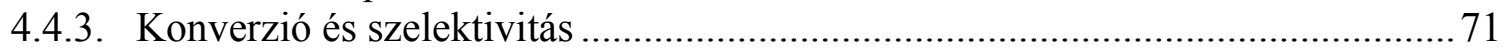

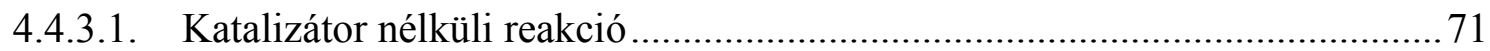

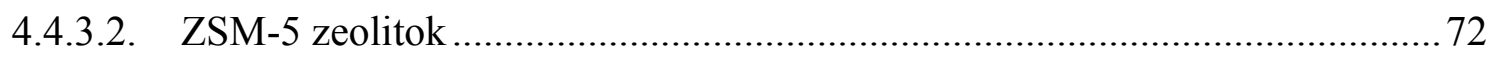

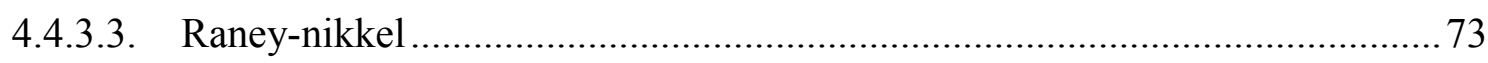

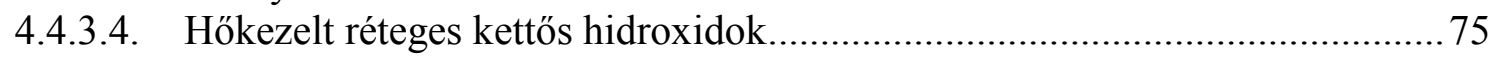

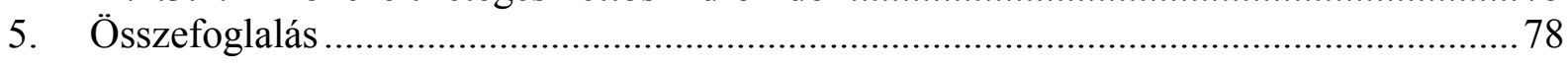

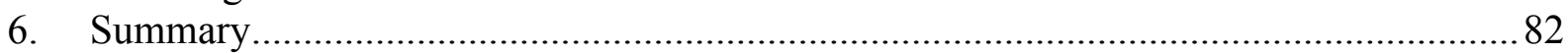

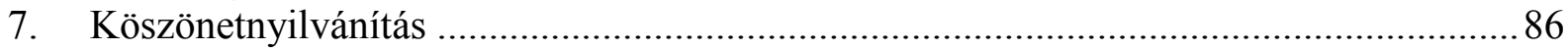

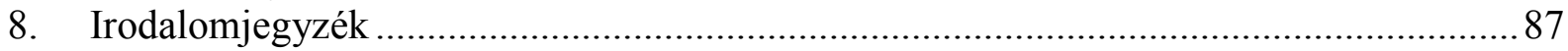




\section{Bevezetés, célkitüzés}

Gazdasági és környezetvédelmi megfontolások alapján a biomassza eredetű motorhajtóanyagok gyártása és felhasználása erőteljesen növekszik. Az Európai Unió különböző szabályozásokkal és előírásokkal is ösztönzi ezt az irányvonalat. A bioetanol és biodízel gyártása ma már nagyüzemi méretekben zajlik. Utóbbi a növényi olajok, állati zsírok vagy használt (és tisztított) sütőolaj metanollal való átészterezésével nyerhető, miközben a biodízel 10 tömeg\%ának megfelelő mennyiségü glicerin is keletkezik.

Arról, hogy mennyire gazdaságos és környezetbarát a bioüzemanyagok termelése és használata, az egymással ellentétben álló szakértőtáborok véleménye a mai napig nem közelít egymáshoz. A dolgozatban felsorakoztatok néhány érvet és ellenérvet, de a téma választásakor abból a nyilvánvaló tényből indultam ki, hogy a termelés nő, ami pedig felveti a melléktermékek felhasználásának, illetve ártalmatlanításának megoldandó problémáját.

A biodízel gyártása bizonyítottan költségesebb, mint a hagyományos, kőolaj alapú motorhajtóanyagok előállítása, így a gazdaságosság növeléséhez a melléktermékek hasznosítása is szükséges. A glicerin felhasználható ugyan - többek között - az élelmiszer- és gyógyszeriparban, de egyrészt annál jóval nagyobb mennyiség keletkezik, mint amit ott alkalmazni tudnának, másrészt a túltermelés miatt az ára is csökken. Ezen kívül a termelőknek elöbb-utóbb problémát okoz a glicerin tárolása és ártalmatlanítása. Mindezt látva a cél tehát az, hogy a glicerint értékesebb finomkémiai termékekké alakítsuk át, ami abból a szempontból is előnyös, hogy ezáltal megtakarítható az a nyersanyag (sokszor a kőolaj), amit azok hagyományos eljárással történő elöállítása során használtunk volna fel.

Számos glicerin átalakítási lehetőséggel találkozhatunk az irodalomban. Éterezéssel üzemanyag- vagy oldószer-adalékokat, felületaktív anyagokat, kenőanyagokat, valamint kozmetikai és élelmiszeriparban használt adalékokat lehet előállítani. Az észterezéssel létrehozott mono-, di vagy trigliceridek többnyire a kozmetikai, élelmiszer-, detergens- és gyógyszeriparban használatosak mint nemionos felületaktív anyagok, emulzióképzők és stabilizálók. A glicerin propionsav-észtere (tripropionin) ígéretesnek tünik dízel üzemanyagban adalékként való felhasználásra. A glicerin acetilezésével nyerhető mono- di- és triacetin a kozmetikai ipartól az üzemanyag-adalékokig sokféle módon alkalmazhatók, beleértve a biológiailag lebomló poliészterek előállítását is. Klórozással epiklórhidrinen keresztül epoxigyanták állíthatók elő, valamint kísérletek folynak a glicerinalapú hidrogén- és szintézisgáz előállítására is. Oxidációval létrehozhatunk gyógyszeripari alapanyagokat, gombaölő szert, vagy akár bőrbarnítót is. A hidrogenolízissel előállítható propándiolok széles körben alkalmazhatók a 
gyógyszer-, élelmiszer-, kozmetikai és vegyiparban a fagyálló folyadékoktól a poliészterek gyártásáig.

A glicerin dehidratációjának fő termékei az acetol és az akrolein. Az acetolt alkalmazzák aromaként, textilfestékként, bőrbarnítók gyártásához, valamint kiindulási alapot biztosít a propilénglikol, akrolein, propionaldehid, és furánszármazékok szintéziséhez. Az akrolein használható akrilsav, akrilgyanta nyersanyagaként, szuperabszorbensek, polimerek és detergensek előállítására, valamint akrilszálak gyártására és kezelésére.

A dehidratációt azonban mellékreakciók is kísérik, ahol többnyire acetaldehid, formaldehid, etilénglikol, és különböző polikondenzációs, ciklikus komponensek jönnek létre. Célul tüztem ki, hogy ezeket a mellékfolyamatokat elkerülve, az akroleint vagy az acetolt a lehetö legjobb glicerinkonverzió mellett minél nagyobb szelektivitással kinyerjük. Mindezt reaktív desztillációs technikával valósítottuk meg. A módszer előnye az, hogy a termékek folyamatos elválasztásával megakadályozhatjuk azok továbbalakulását, ezzel is növelve a szelektivitást.

Ennek elérése érdekében jellegükben eltérő katalizátorokat teszteltünk. A kipróbált minták között voltak a különbözö fémekkel módosított (savas) ZSM-5 zeolitok, és fémes karakterü, új típusú - nem piroforos - Raney-nikkel (RNi)-katalizátorok. Előbbi szintézise tanszékünkön történt, utóbbit tesztelés céljából kaptuk a feltalálótól, néhai Petró Józseftől. Kipróbáltam még a bázikus tiszta és módosított MgAl-hidrotalcitokból hőkezeléssel nyert keverékoxidokat, melyek savas és bázis helyeket is szolgáltathatnak a reakció lejátszódására.

A reaktív desztillációt követően a desztillátum és a desztillációs maradék tömegéből és térfogatából anyagmérleget számoltam. A mennyiségi és minőségi termékösszetételt gázkromatográf segítségével határoztam meg, amiből a konverzió és a szelektivitás kiszámítható.

A desztillációs maradéktól centrifugálással elválasztottam a katalizátort, melyet mostam, szárítottam, majd hökezeléssel regeneráltam, hogy azt újabb reakcióban tesztelhessem.

A használat előtti, és használt, illetve a regenerált, valamint a „nyers” (,,as-prepared”) mintákat (hidrotalcitok) különböző módszerekkel tanulmányoztam. A kristályszerkezetről, részecskeméretről, rétegtávolságról röntgediffraktométerrel, a fajlagos felületről és a pórusokról nitrogén adszorpciós berendezéssel, a termikus stabilitásról és a hőmérséklet hatására bekövetkező változásokról pedig termikus analízissel nyertem információkat. 


\section{Irodalmi elözmények}

\subsection{Bio-motorhajtóanyagok}

A kőolajkészletek végesek, áruk növekszik, a világ nagy része pedig energetikailag attól a néhány országtól függ, amelyek fosszilis energiahordozókban gazdagok. Sokat hallani a globális klímaváltozás és egyéb, fơképp a kőolaj és kőszén túlzott használatának tulajdonított környezeti problémákról. Ezeknek a mérséklésére irányul az alternatív energiaforrások minél nagyobb arányú használatának ösztönzése.

A bioüzemanyagok előnye, hogy elégetésükkor csak annyi $\mathrm{CO}_{2}$ keletkezik, mint amennyit a növény, amelyből előállították, az élete során szervezetébe épített.

Az úgynevezett első generációs biohajtóanyagok (bioetanol, biodízel, biogázolaj) gyártása ma már nagyüzemi méretekben történik. A felmerülő környezetvédelmi (és etikai) problémák ösztönözték a második (nem élelmiszeralapú, lignocellulózból, biomassza alapú szintézisgázból és szilárd biomasszák elfolyósításával, algákkal nyert motorhajtóanyagok) és a harmadik generációs (biológiai eredetủ alapanyagokból nyert hidrogén elektromos energia termelésére) bioüzemanyagok előállítását, de ezek többnyire még csak kísérleti stádiumban vannak.

Az Európai Unió környezetvédelmi politikája különböző irányelvekkel ösztönzi a biomotorhajtóanyagok termelésének és használatának növelését [1]. Közülük a legfontosabbak:

A közlekedési ágazatban a bioüzemanyagok, illetve más megújuló üzemanyagok használatának előmozdításáról szóló, 2003. május 8-i 2003/30/EK európai parlamenti és tanácsi irányelv [2];

A benzin és a dízelüzemanyagok minőségéről, valamint a 93/12/EGK tanácsi irányelv módosításáról szóló, 1998. október 13-i 98/70/EK európai parlamenti és tanácsi irányelv (Fuel Quality Directive) $[3,4]$;

A megújuló energiaforrásból előállított energia támogatásáról, valamint a 2001/77/EK és a 2003/30/EK irányelv módosításáról és azt követő hatályon kívül helyezéséről szóló, 2009. április 23-i 2009/28/EK európai parlamenti és tanácsi irányelv (Renewable Energy Directive) $[5]$;

A benzinre, a dízelolajra és a gázolajra vonatkozó követelmények, illetőleg az üvegházhatású kibocsátott gázok mennyiségének nyomon követését és mérséklését célzó mechanizmus bevezetése tekintetében a 98/70/EK irányelv módosításáról, a belvízi hajókban felhasznált tüzelőanyagokra vonatkozó követelmények tekintetében az 1999/32/EK irányelv módosításáról, valamint a 93/12/EGK irányelv hatályon kívül helyezéséről szóló, 2009. április 23-i 2009/30/EK európai parlamenti és tanácsi irányelv (Climate Change and Energy Package) [6]. 


\subsection{A biodízel technológiai, gazdasági és társadalmi kérdései}

\subsubsection{Statisztikai adatok}

Az Európai Unió biodízel piacának növekedése lassult a 2009-2010. években, ami feltehetően a vámmentes (legnagyobb mennyiségben Argentínából és Indonéziából származó) import áru nyersanyag árán aluli értékesítése következtében történt. A termelés 2009-ben évi 9 millió tonna volt, ami a következő évben 9,57 millió tonnára nőtt, majd 2011-ben kissé visszaesett (8,6 millió tonna), de még így is jelentős (1. ábra). Tekintve, hogy az európai biodízelgyártás-kapacitás 2012-ben 23,5 millió tonna, lényegesen nagyobb mennyiség termelésére is képes lenne, mellyel elérhetné a 2020-ra tervezett $10 \%$-os arányt is. Európában a három legnagyobb biodízelgyártó ország Németország, Franciaország és Spanyolország. Hazánk a középmezőnyben található évi 150 ezer tonna termeléssel [1].

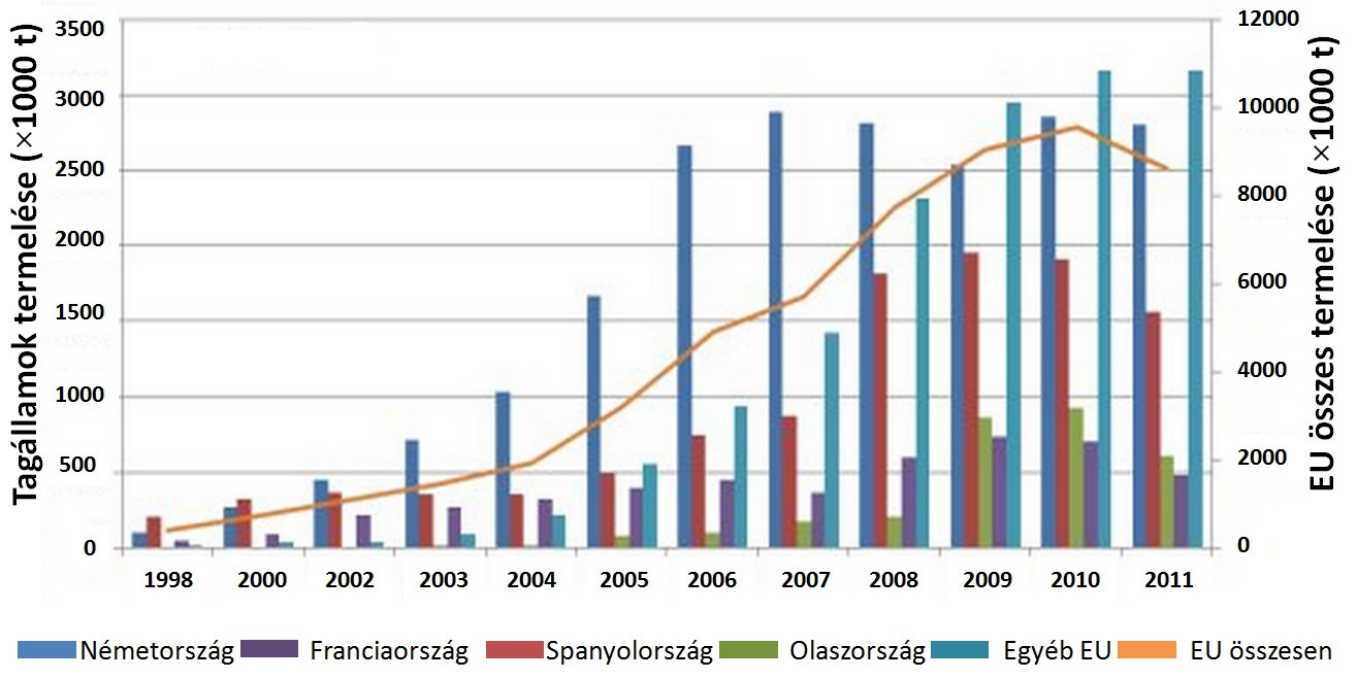

1. ábra: Az EU biodízel-gyártásának változása az elmúlt években [1]

A 2009/28/EK [5] irányelv azzal, hogy elfogadta, hogy a közlekedésben használt energiák 10 \%-a megújuló energiaforrásból származzon, megteremtette az alapját a bioüzemanyag-ipar fejlesztésének. A vetésforgóval és azzal, hogy újrahasznosított olajokat és állati termékeket is használnának biodízel gyártására, valamint alternatív nyersanyagokkal (pl. alga) az európai biodízelgyártás úgy lenne növelhető, hogy közben nem zsákmányolnánk ki a termőföldet. Az EU 2020-ban mezőgazdasági területeinek csak 4 \%-át használná biodízel-alapanyag termelésére [1]. 


\subsection{2. Érvek, ellenérvek a bioüzemanyagokról}

Számos érv és ellenérv szól a bioüzemanyagok használata mellett és ellen [7-9], melyek főbb aspektusait az 1. táblázat foglalja össze.

1. táblázat: Érvek és ellenérvek a bioüzemanyagokkal kapcsolatban

\begin{tabular}{|c|c|c|}
\hline Szempont & Mellette & Ellene \\
\hline $\begin{array}{l}\text { Befektetett } \\
\text { és kinyert } \\
\text { energia } \\
\text { mérlege }\end{array}$ & $\begin{array}{l}\text { a mérleg pozitív, és az adott éghaj- } \\
\text { laton termelt növény helyes megvá- } \\
\text { lasztásával, a technológia javításával } \\
\text { és a melléktermékek felhasználásával } \\
\text { tovább javítható }\end{array}$ & $\begin{array}{l}\text { elóállításukhoz több energia szük- } \\
\text { séges, mint amit használatukkal ki } \\
\text { tudunk nyerni [10] }\end{array}$ \\
\hline $\begin{array}{l}\mathrm{CO}_{2} \text {-sem- } \\
\text { legesség }\end{array}$ & $\begin{array}{l}\text { elégetésükkor csak annyi } \mathrm{CO}_{2} \text { szaba- } \\
\text { dul fel, mint amennyit az élete során } \\
\text { megkötött a növény, amiböl azt ké- } \\
\text { szítették }\end{array}$ & $\begin{array}{l}\text { ha egy adott területen megmaradna } \\
\text { az erdő, az több } \mathrm{CO}_{2} \text {-t kötne meg, } \\
\text { mint amit azon a földön termelt bio- } \\
\text { üzemanyagokkal megspórolhatunk; } \\
\text { előállítása nagy mennyiségü fosz- } \\
\text { szilis energiahordozó felhasználását } \\
\text { igényli }\end{array}$ \\
\hline $\begin{array}{l}\text { Élelmiszer/ } \\
\text { takarmány } \\
\leftrightarrow \\
\text { bioenergia- } \\
\text { termények }\end{array}$ & $\begin{array}{l}\text { a bioenergia-termények előállítására } \\
\text { szükséges területnek nagy részét biz- } \\
\text { tosítaná az a földterület, amit a túlzott } \\
\text { termelés elkerülése végett egyébként } \\
\text { pihentetni kényszerülnének a gazdák; } \\
\text { hozzájárul az agrártúltermelés csök- } \\
\text { kentéséhez; } \\
\text { segíti a mezőgazdasági munkahelyek } \\
\text { megtartását }\end{array}$ & $\begin{array}{l}\text { gabona ára nő; } \\
\text { EU mezőgazdasági területeinek 4-13 } \\
\text { \%-án kellene bioüzemanyag előállí- } \\
\text { tására alkalmas növényeket termesz- } \\
\text { teni }\end{array}$ \\
\hline $\begin{array}{l}\text { Környezeti } \\
\text { hatások }\end{array}$ & $\begin{array}{l}\text { erdők, vizes területek és magas bio- } \\
\text { diverzitási indexü gyepek helyére te- } \\
\text { lepített bioenergia-növények tiltása }\end{array}$ & $\begin{array}{l}\text { nagyobb víz-, mütrágya- és növény- } \\
\text { védőszer-igény megterheli a talajt, a } \\
\text { vízbázist, a légkört, hozzájárulva az } \\
\text { üvegházhatáshoz és savas esők kiala- } \\
\text { kulásához; } \\
\text { biológiai sokféleség csökkenése }\end{array}$ \\
\hline
\end{tabular}




\begin{tabular}{|l|l|l|}
\hline \multirow{3}{*}{ Ár } & adókedvezményekre, -mentességre & bioüzemanyagok drágábbak, mint a \\
van szükség, hogy versenyképessé & hagyományos fosszilis tüzelőanya- \\
& tegye; & gok \\
& a második generációs bioüzemanya- \\
& gok olcsóbbnak ígérkeznek & a második generációs bioüzemanya- \\
& gok még fejlesztés alatt állnak
\end{tabular}

Az összetett problémakör etikai, gazdasági, környezeti és egyéb szempontból történő vitatása azonban túlmutat az értekezés keretein. Az viszont tény, hogy a jelenlegi intézkedések arra irányulnak, hogy a bioüzemanyagok, köztük a biodízel gyártását növeljék. A keletkező melléktermékeket pedig célszerü és szükséges valamilyen módon hasznosítani.

\subsubsection{Növényi olaj és biodízel}

A tiszta növényi olaj közvetlenül is felhasználható motorhajtóanyagként, de ehhez a motort át kell alakítani. Viszkozitása nagy, gyenge az üzemanyag atomizálódása, megnő a motor fogyasztása, tökéletlen az égés [11], és kellemetlen szagot bocsát ki. Átészterezéssel azonban ezek a gondok kiküszöbölhetők.

Növényi olajok (leginkább szója, repce, napraforgó és pálma) és állati zsírok bázikus vagy savas katalizátor jelenlétében történő metanollal való átészterezése során C16-C18 zsírsavak metil-észtereinek (FAME) keverékét kapjuk, ami nem más, mint maga a biodízel (2. ábra). A folyamat során minden $3 \mathrm{~mol}$ metil-észter elöállításakor 1 mol glicerin is keletkezik, más szóval $1 \mathrm{~kg}$ nyers glicerin keletkezik minden $9 \mathrm{~kg}$ előállított biodízel mellett $[12,13]$.

Az így kapott motorhajtóanyagról elmondható, hogy aromásmentes, nem mérgező, nem képez robbanóelegyet és könnyen biodegradálható. Használatakor a jó gyulladási hajlam miatt a motorzaj kicsi, és teljesítménye közel azonos a hagyományos dízelével [8, 9].

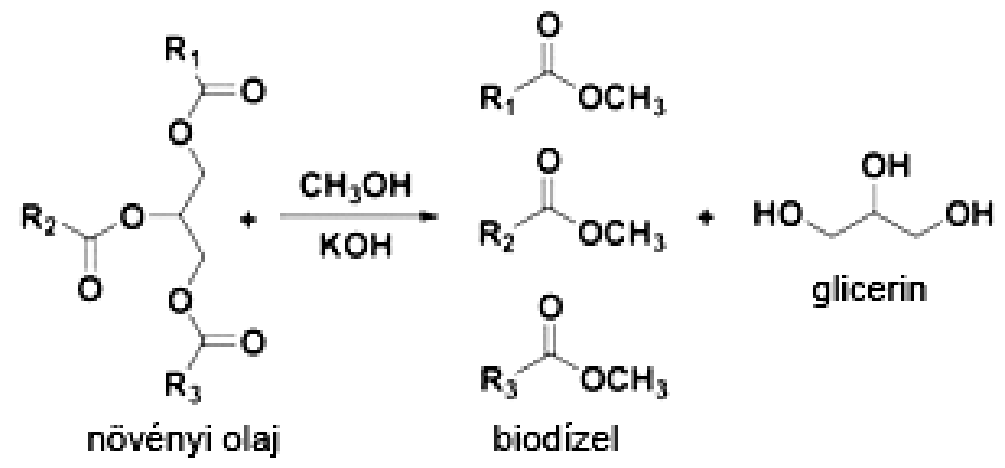

2. ábra: Növényi olaj átészterezése [13] 
A kibocsátott füstgáz $\mathrm{SO}_{x^{-}}, \mathrm{CO}-$, szénhidrogén- és szilárd részecsketartalma alacsonyabb, mint a hagyományos dízelé $[11,14,15]$. Csak $\mathrm{NO}_{\mathrm{x}}$-tartalma nagyobb, de azt jelentősen csökkenteni lehet késleltetett befecskendezéssel és redukciós katalizátorral [8,9].

Mivel a biodízel tartalmazhat vizet és szabad $\mathrm{OH}$-csoporttal rendelkező vegyületeket is, magas a hidrolízis-érzékenysége, megtámadhatja a gumitömlőket, ezért a vele érintkezésbe kerülö vezetékeket és tömítéseket polietilénre vagy fémre kell kicserélni. Oldószer jellegü viselkedése folytán károsíthatja a lakkozott alkatrészeket is $[8,9,16]$.

Gond lehet még a biodízel használatával kapcsolatban, hogy a magasabb CFPP (hidegszürhetőségi határhőmérséklet) és a nagyobb viszkozitás hidegindítási- és porlasztási nehézségekhez vezet. Dermedéspontja $-10{ }^{\circ} \mathrm{C}$, szemben azzal, hogy a hagyományos dízel $-15--20{ }^{\circ} \mathrm{C}-$ on ,áll össze” $[8,9,15]$.

Kisebb szerkezeti átalakításokkal - vagy akár a motor változtatása nélkül is - hagyományos dízellel (5\%-os keverési arány) való keveréssel a fenti problémák mind elkerülhetők [8, 9, 16]. A biodízel $(37-41 \mathrm{MJ} / \mathrm{kg})$ energiatartalma összevethető a hagyományos dízelével (36-45 MJ/kg), azzal jól keverhető, és ráadásul a kismértékben biodízelt is tartalmazó keverék-üzemanyag jelentős mértékben javítja a dízelolajok kenőképességét [9]. A keverékek közül legismertebb a B20, mely $20 \%$ biodízelt és $80 \%$ dízelt tartalmaz.

\subsubsection{Biodízelgyártás}

A szakirodalom számos biodízel-előállítási technológiát említ. A reakció lényegében katalitikus átészterezés.

Homogén katalízissel metanolban jól oldódó erős bázisokkal $\left(\mathrm{KOH}, \mathrm{NaOH}, \mathrm{CH}_{3} \mathrm{O}-\mathrm{Na}\right)$ már környezeti nyomáson és hömérsékleten is lehet biodízelt elöállítani. A kapott terméket tisztítani kell a maradék katalizátortól és a glicerintől, ami vízigényes folyamat [17], ráadásul szappanok is képződhetnek, melyek stabilizálják az emulziót. A technológiai problémák csökkentése érdekében más módszereket is tanulmányoztak, úgymint a homogén savas katalízist [18], szuperkritikus [19], enzimatikus [20], illetve heterogén katalitikus eljárásokat.

Heterogén savas katalízisben használt legismertebb katalizátorok a szulfatált fém-oxidok [21], heteropolisavak [22], szulfonált amorf szén [23] és a savas ioncserélö gyanták [24]. Ezek hátránya, hogy mivel kisebb az aktivitásuk, magasabb reakcióhőmérsékletet és hosszabb reakcióidőt kell alkalmazni [25]. A nagyobb aktivitású bázisos katalizátorok között említést érdemelnek a fém-oxidok [26], módosított zeolitok [27], hidrotalcitok [28] és az anioncserélő gyanták [29]. Nagy bázikussága, kis oldhatósága, alacsony ára és a KOH-dal összehasonlítva könnyü kezelhetősége miatt a $\mathrm{CaO}$ az egyik legjobban kutatott heterogén katalizátor [30]. 
A biodízelgyártás kiindulási anyaga lehet növényi olaj, állati zsiradék, de használt sütőolaj is. Utóbbi esetben 100 egység használt sütőolajból kiindulva először vákuum alatt elpárologtatják a vizet, majd 40-50 egység metanollal, 0,02-0,6 egység katalizátor jelenlétében átészterezik. Ezután elválasztják a glicerint (21,5-13,8 egység), az át nem alakult olajat, a katalizátort és a metanolt (24-37 egység). Ezt követően vagy forró vizes mosással majd vákuumdesztillációval távolítják el utóbbi anyagok kis mennyiségü maradékát és a felesleges vizet, vagy desztillációval választják el a FAME-t a visszamaradó hulladék olajtól. A keletkező biodízel mennyisége 89-92 egység [25].

Az elválasztott metanolfelesleget újra felhasználják, a szennyvizet kezelik, a hulladék olajat és a glicerint pedig elégetik [25], bár utóbbi tisztítás után értékes anyagokká alakítható. A glicerin tartalmaz vizet, észterező alkohol, illetve zsírsav-észterek maradékait, szappant, elhasználatlan katalizátort, vagy annak semlegesítésével keletkező sókat. A szappanokat savval meg lehet bontani, és ezzel a zsírsavak egy elkülöníthető fázisban jelennek meg. Semlegesítéssel sók válnak ki, melyek szüréssel eltávolíthatók. A víz és az alkohol desztillációval való elválasztása után a nyers glicerin tisztasága 90 tömeg\% felettire nő [31].

\subsection{A melléktermék glicerin felhasználási és átalakítási lehetőségei}

Láthatjuk tehát, hogy a ma alkalmazott gyártási technológiákban a zsírsav-metilészterek mellett jelentős mennyiségü glicerin keletkezik. Ennek hasznosítása mindenképp célszerü és szükséges. A keletkező felesleg ugyanis a közeljövőben nemcsak hulladékproblémát okozhat, de a túltelített piac miatt a glicerin ára csökken, ami gátat szabhat az iparág fejlődésének, és a biodízel alkalmazását is visszavetheti. Ezzel szemben a melléktermékek hasznosításával a biodízel gyártása is gazdaságosabbá tehető.

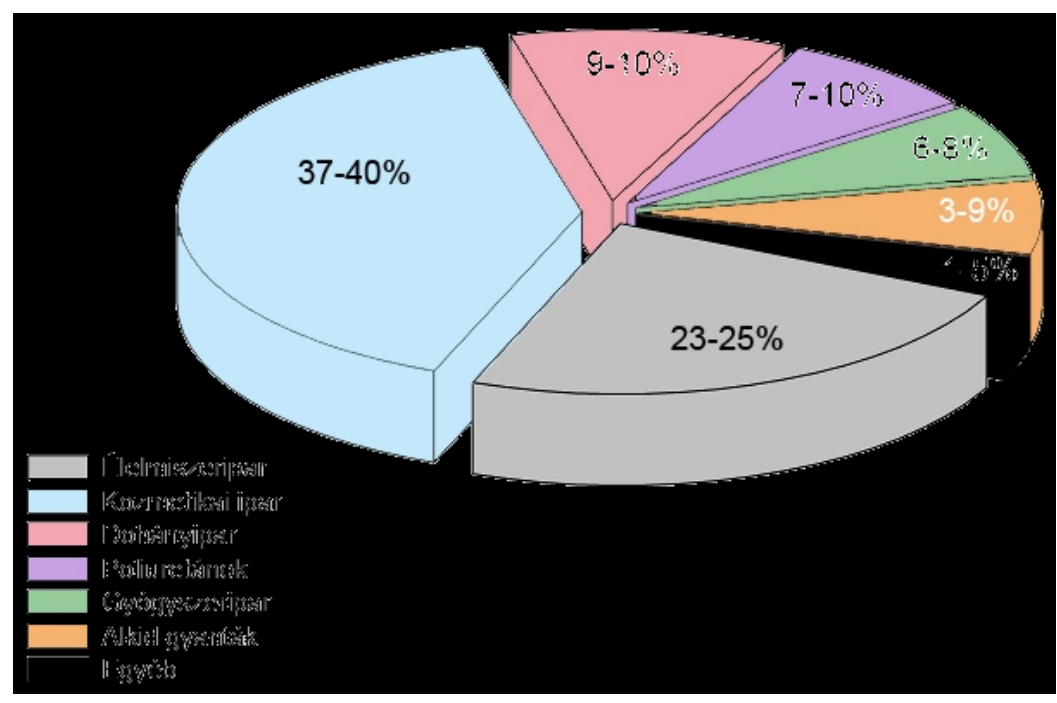

3. ábra: Glicerin felhasználása a különböző iparágakban [32] 
A glicerin egy részét közvetlenül használják fel adalékanyagként, állagjavítóként többek között a gyógyszer-, a kozmetikai és az élelmiszeriparban (3. ábra), másrészt kifejezetten jó kiindulási anyag a finomvegyipari termékek előállításához, ezért az is hasznos lehet, ha valamilyen kémiai vagy biotechnológiai folyamatban értékes termékekké, vagy energiahordozókká alakítanánk át. Ezen túl, ha az adott finomkémiai termékeket megújuló forrásból származó melléktermékből állítanánk elő, akkor a szénsemleges eljárással nemcsak az egyre dráguló és véges mennyiségü kőolajat lehetne kiváltani, hanem a környezetkárosítás is csökkenthető lenne, ami a zöldkémia egyik (hetedik) alapelvének is megfelelne [33].

Nagyszámú átalakításra irányuló kutatásról lehet olvasni az irodalomban. A 4. ábra néhány ilyen lehetőséget mutat be.

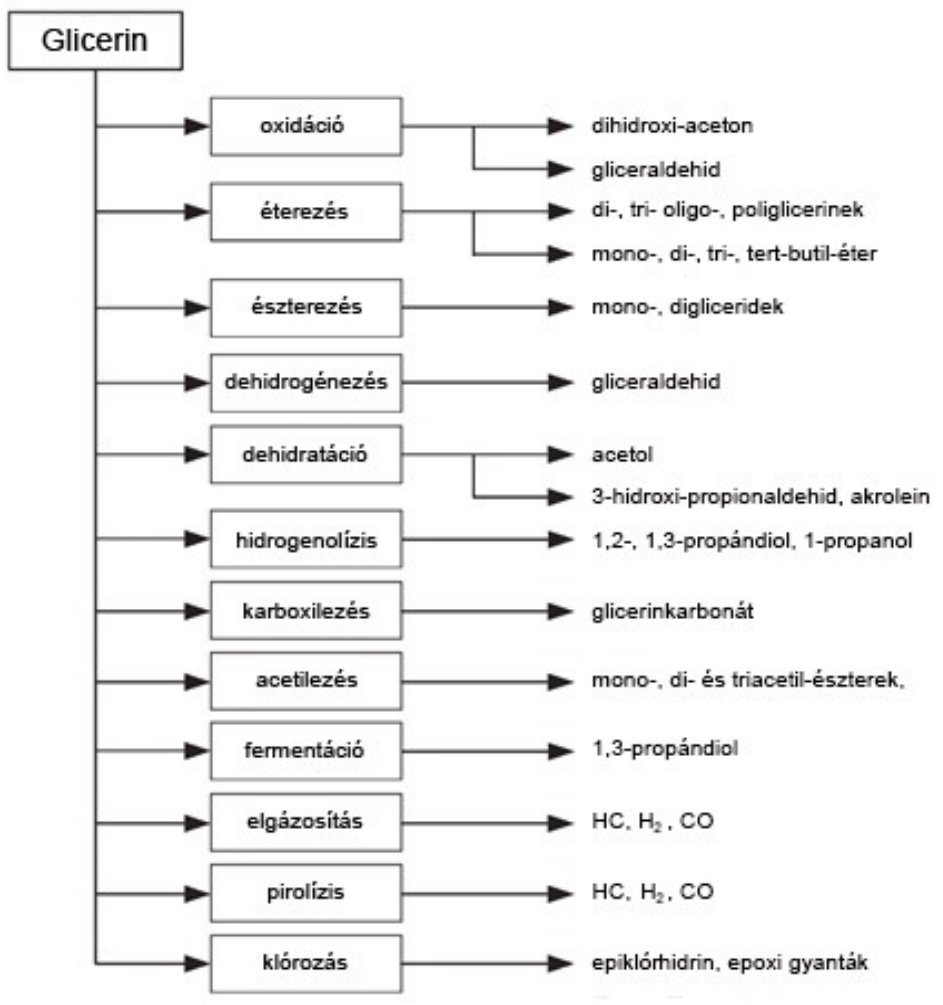

4. ábra: A glicerin néhány átalakítási lehetősége

\subsubsection{Glicerinéterek előállítása és felhasználása}

A glicerin alkoholokkal (metanol, etanol) vagy alkénekkel (izobutén) történő éterezése lehet az átalakítás egyik alternatívája. Az utóbbi esetben keletkező, elágazó szénláncú, oxigént tartalmazó komponensek kiválóan használhatók üzemanyag- vagy oldószer-adalékként [12].

A glicerinből származó tercier-butil-éterek potenciális lehetőséget jelentenek az olyan oxigéntartalmú benzinkomponensek kiváltására, mint az ETBE (etil-tercier-butil-éter) vagy az MTBE (metil-tercier-butil-éter) [12]. 
Glicerin izobuténnel történő éterezésében használhatnak nagy pórusméretü zeolitokat [34], savas homogén katalizátorokat vagy erösen savas ioncserélő gyantát [12, 34]. Ez utóbbi (Amberlyst) katalizátor jelenlétében magas glicerinkonverzió mellett kiemelkedő (92\%) di-és triéter-szelektivitást értek el [34]. A tercier-butil-alkohol is ismert éterező ágens, mely szintén alkalmazható zeolit [34], vagy Amberlyst savas ioncserélö gyanta katalizátorok [34, 35] jelenlétében.

Glicerin szelektív éterezésével poliglicerineket lehet elöállítani (5. ábra), például Cs-impregnált MCM-41 [36] vagy bázikus ioncserélt zeolitkatalizátorok [37] jelenlétében. A poliglicerinek és poliglicerin-észterek kiválóan alkalmazhatók, mint felületaktív anyagok, kenőanyagok, valamint adalékok a kozmetikai és élelmiszeriparban [36].

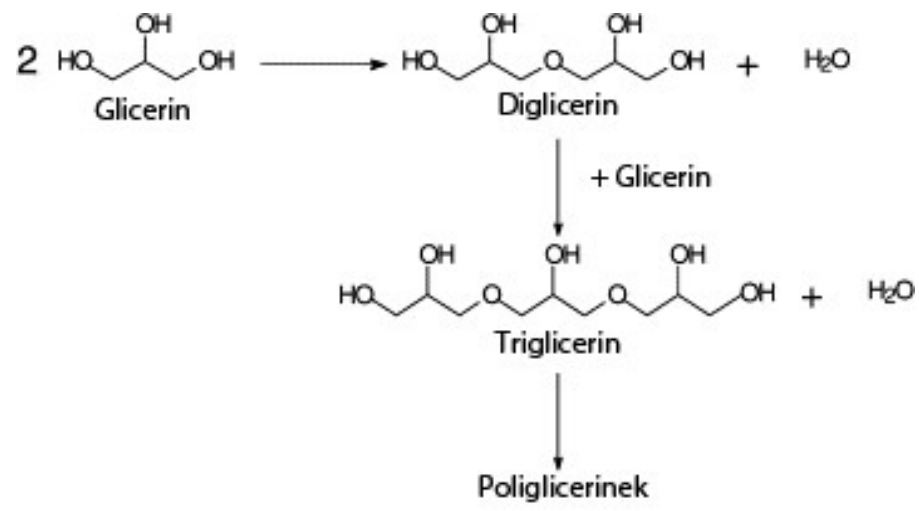

5. ábra: Glicerin poliglicerinné való éterezése [36]

\subsubsection{A glicerin észterezése}

Legfontosabb származékoknak talán az észterek tekinthetők. A mono- és digliceridek ipari előállítására három technológiai módszer terjedt el. A trigliceridek hidrolízise mellett egyrészt a glicerin zsírsavakkal történő észterezése valamilyen savkatalizátor (kénsav [38, 39], nagy pórusú zeolit [40, 41] vagy kationos gyanta [42]) jelenlétében, másrészt a báziskatalizált triglicerid-átészterezés, ami zsírok vagy olajok glicerolízisét (6. ábra) jelenti [38, 39].

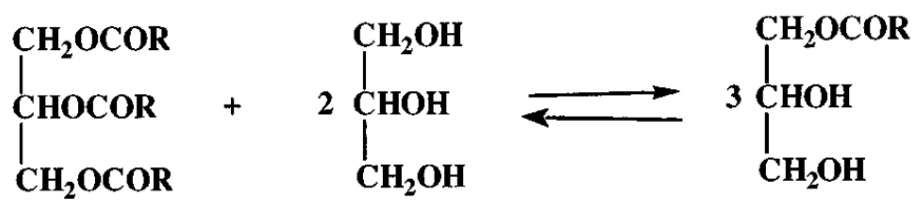

6. ábra: Növényi olajok glicerinnel való átészterezése [38]

Corma és munkatársai olyan bázikus katalizátorok jelenlétében vizsgálták a monogliceridek előállítását, mint a szepiolit-Na-Cs, MCM-41-Cs, $\mathrm{MgO}$, és különböző $\mathrm{Al} / \mathrm{Al}+\mathrm{Mg}$ arányú 
hidrotalcitok [38]. A MgO bázikusságát $-\mathrm{s}$ ezáltal aktivitását $-\mathrm{Li}^{+}$beépítésével sikerült növelni [43]. Mivel ezek a katalizátorok a reakcióelegyböl szüréssel könnyedén eltávolíthatók, elkerülhető a melléktermékek képződése, és nem szükséges semlegesre mosni, míg ez a hagyományos eljárásoknál elengedhetetlen [38].

A monogliceridek többnyire a kozmetikai, élelmiszer-, detergens- és gyógyszeriparban használatosak mint nemionos felületaktív anyagok [40], emulzióképzők [44] és stabilizálók [45].

A glicerin propionsav észtere (tripropionin) ígéretesnek tünik dízel üzemanyag-adalékként való felhasználásra. A glicerin és megfelelő feleslegben alkalmazott propionsavanhidrid reakciójával 100 \%-os konverzióval és szelektivitással állítható elő [31].

\subsubsection{A glicerin acetilezése}

A glicerin ecetsavval történő acetilezése során mono-, di- és triacetil-észtereket (mono- diés triacetin) kapunk (7. ábra), melyek a kozmetikai ipartól az üzemanyag-adalékokig sokféle módon alkalmazhatók [46, 47], beleértve a biológiailag lebomló poliészterek előállítását [48].

A reakció megvalósítása során a K-10 montmorillonitot és a HZSM-5 zeolitot összevetve az Amberlyst-15-tel, a legjobb konverziót és szelektivitást a savas ioncserélő gyanta esetében érték el. Feltehetően a katalizátorok felületén lévő erős savas helyek jelenlétével magyarázható, hogy minden esetben detektáltak a glicerin dehidratációjából származó acetolt is [13].

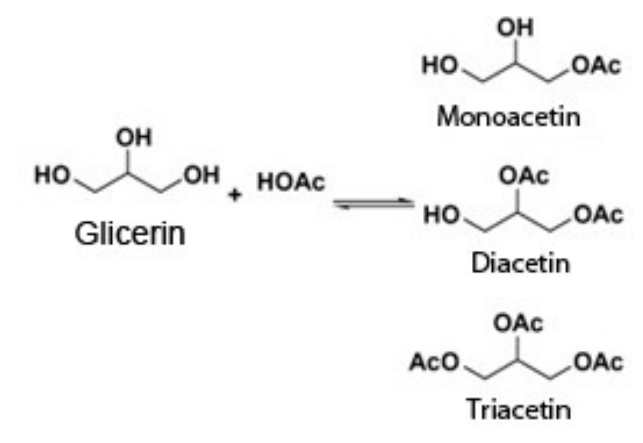

7. ábra: Glicerin acetilezése ecetsavval [13]

\subsubsection{Szintézisgáz előállítása glicerinből}

Pt-tartalmú ( $\mathrm{C}$ vagy $\mathrm{CeO}_{2} / \mathrm{ZrO}_{2}$ hordozóra vitt $\mathrm{Pt}$ ) katalizátor jelenlétében a glicerin szintézisgázzá ( $\mathrm{H}_{2}$ és $\mathrm{CO}$ elegye) alakítható $225-350{ }^{\circ} \mathrm{C}$ hőmérsékleten. A szintézisgázból különböző üzemanyagok és kemikáliák gyárthatók. Ha ezt az endoterm átalakítást összekapcsoljuk az exoterm Fischer-Tropsch és metanol-szintézissel, akkor a fenti termékek energiahatékony úton állíthatók elő [49]. 


\subsubsection{Hidrogén előállítása glicerin alapon}

Intenzív kutatások folynak annak érdekében, hogy hidrogén üzemanyagcella segítségével környezetbarát energiát állítsanak elö, hogy úgy tudjanak nagy hatékonyságot elérni, hogy közben melléktermékként egyedül víz keletkezik. Az igazán környezetbarát megoldás az lenne, ha az üzemanyagként használt hidrogént is megújuló forrásból nyernék, és ezáltal a folyamatot $\mathrm{CO}_{2}$-semlegesnek lehetne tekinteni.

Gőzreformálással (steam reforming) vagy vizes fázisú reformálással (aqueous-phase reforming, $A P R)$ történő hidrogéngyártásban ideális nyersanyagnak tekinthetők a biomasszaeredetü, oxigéntartalmú szerves vegyületek [50-52]. A folyamat glicerin esetében a következő bruttó egyenlettel írható le [50]:

$$
\mathrm{C}_{3} \mathrm{H}_{8} \mathrm{O}_{3}+3 \mathrm{H}_{2} \mathrm{O} \rightarrow 3 \mathrm{CO}_{2}+7 \mathrm{H}_{2} \text {. }
$$

Elöfordul, hogy CO keletkezik, mint köztitermék, ami szénmonoxid-konverziós reakcióban továbbalakul $\mathrm{CO}_{2}$-dá:

$$
\mathrm{CO}+\mathrm{H}_{2} \mathrm{O} \rightleftharpoons \mathrm{H}_{2}+\mathrm{CO}_{2}
$$

illetve a keletkezett hidrogén reakcióba lépve a szén-monoxiddal, vagy szén-dioxiddal, alkánok vagy alkének képződését eredményezi. A folyamatban ideális katalizátornak tehát meg kell felelnie a következőknek: hasítaniuk kell a $\mathrm{C}-\mathrm{C}, \mathrm{O}-\mathrm{H}$ és $\mathrm{C}-\mathrm{H}$ kötéseket, s elő kell, hogy segítsék a CO-konverziót, hogy ezáltal az adszorbeálódott CO-ot eltávolítsák a felületröl, viszont ne szakítsák a $\mathrm{C}-\mathrm{O}$ kötést és ne hidrogénezzék alkénekké a $\mathrm{CO}$-ot vagy a $\mathrm{CO}_{2}$-ot [52].

Glicerin vizes fázisú reformálásában alkalmaztak $\mathrm{Al}_{2} \mathrm{O}_{3}$ hordozóra vitt Pt-t, Ni-t, NiSn-t illetve Raney-Ni (RNi) és Raney-NiSn (RNiSn) katalizátorokat. A RNiSn katalitikus tulajdonságai összemérhetőek a sokkal drágább $\mathrm{Pt} / \mathrm{Al}_{2} \mathrm{O}_{3}$-éval, viszont 1-5 tömeg\%-os híg glicerin vizes oldat esetén is maximum 50-80\% hidrogénképződést sikerült elérni [51, 52].

Ezzel szemben $\mathrm{CeO}_{2}$ hordozóra vitt irídiumkatalizátor használatával teljes glicerinkonverziót és $85 \% \mathrm{H}_{2}$-szelektivitást valósítottak meg $400{ }^{\circ} \mathrm{C}$-on és atmoszférikus nyomáson. $\mathrm{Co} / \mathrm{CeO}_{2}$ - és $\mathrm{Ni} / \mathrm{CeO}_{2}$-katalizátorok esetén a teljes konverzió csak magasabb hőmérsékleten valósult meg, és a $\mathrm{H}_{2}$-szelektivitás is az $\mathrm{Ir} / \mathrm{CeO}_{2}$ jelenlétében tapasztaltak alatt maradt [50].

\subsubsection{A glicerin karboxilezése}

Glicerinből szén-dioxiddal karboxilezve óntartalmú katalizátor jelenlétében közvetlenül, vagy dimetil-karbonát keletkezésén és átészterezésén keresztül glicerinkarbonát ( 8 . ábra) állítható elö [53], melyet új, funkcionalizált polimerek szintézisére használhatunk [54]. 


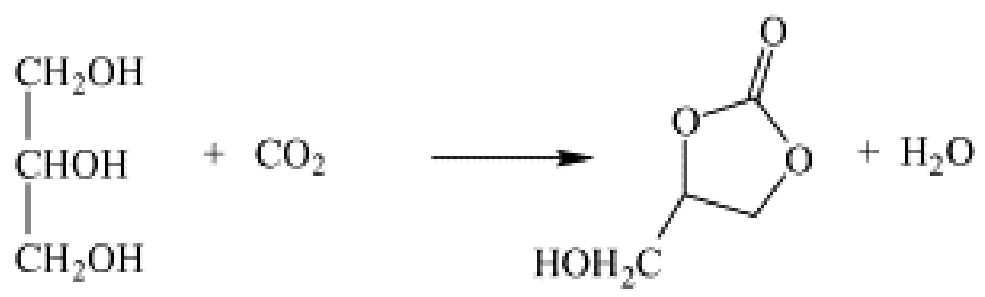

8. ábra: Glicerin közvetlen karboxilezése [53]

\subsubsection{Glicerin átalakítása klórozással}

A múltban a glicerin előállításának egyik alapanyaga az epiklórhidrin volt. Ma erre már nincs szükség, mert így is kezd túltelítetté válni a glicerinpiac. Azonban a reakció ötletet adott arra, hogy a folyamatot megfordítva glicerinből állítsanak elő epiklórhidrint (9. ábra), amit aztán az epoxigyanták gyártásában hasznosíthatnak. A glicerinalapú eljárás összehasonlítva a hagyományos, propénból kiinduló módszerrel, több szempontból is előnyösnek mondható. Egyrészt megújuló alapanyagot használ, másrészt kevesebb a vízigénye, kevesebb klórozott maradék keletkezik, és klórozó ágensként sósavat használ a drágább klór helyett [55].

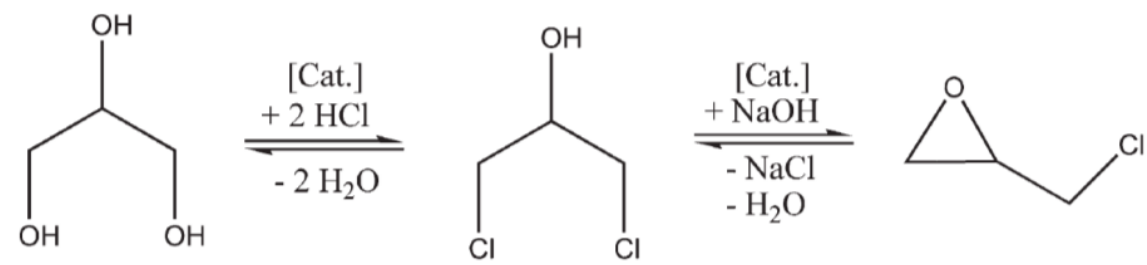

9. ábra: Glicerin epiklórhidrinné alakítása [56]

\subsubsection{Oxidáció}

Tekintve, hogy a glicerin magasan funkcionalizált molekula, oxidációja összetett (10. ábra) és számos, a finomkémiában értékes termék keletkezéséhez vezethet [57, 58].

A glicerinsav fontos gyógyszeripari alapvegyület, hiszen az élő szervezet glikolízisének lebontási terméke, és így sokféle funkciós csoport építhető rá, valamint fontos nyersanyaga a különböző optikai izomereknek is [59].

Az 1,3-dihidroxi-aceton, ami elsődleges oxidációs termék, használható bőrbarnítóként a kozmetikai iparban, valamint gombaölő szerek alapanyagaként is [60].

Az oxidáció indulhat primer vagy szekunder hidroxilcsoporton. Ez többek között függ a katalizátortól, annak előállítási és előkezelési körülményeitől is [61].

A glicerin vizes fázisú oxidációjában a $\mathrm{Pt}(+\mathrm{Au}) / \mathrm{C}-[61] \mathrm{Au} / \mathrm{C}-[57]$ és az $\mathrm{Au} / \mathrm{TiO}_{2}-\mathrm{katalizá}^{-}$ torok [62] sikeresen alkalmazhatók. Azt is megállapították, hogy a részecskeméret befolyá- 
solja a reakcióutat [57], valamint azt is, hogy a platina, mint promotor alkalmazása javította az $\mathrm{Au} / \mathrm{C}$-katalizátor aktivitását és dihidroxi-acetonra vonatkoztatott szelektivitását [58].

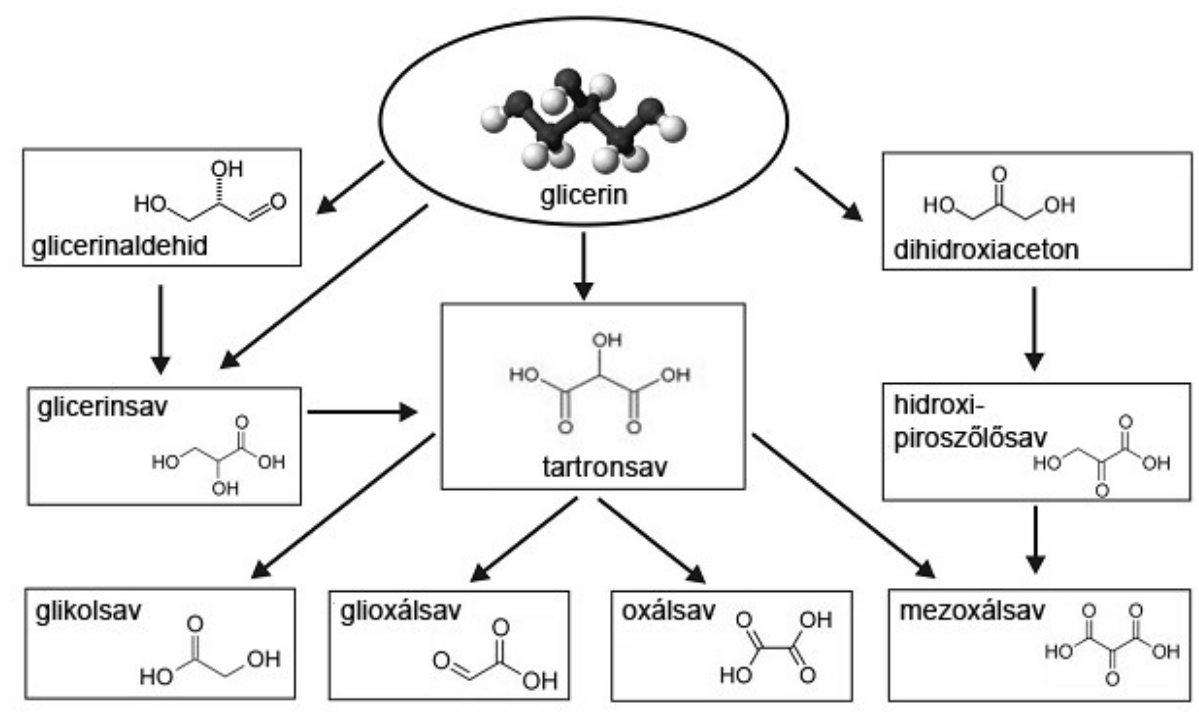

10. ábra: Glicerin oxidációja [57]

Levegővel végrehajtott szelektív oxidációban a Pd/C-katalizátor bázikus környezetben 80 \%-os hozammal glicerinsavat eredményezett, míg a dihidroxi-aceton képződésének a savas $\mathrm{pH}$ és a Pt-Bi/C jelenléte kedvezett [60].

\subsubsection{A glicerin dehidratációs reakciói}

A glicerin dehidratációjának lehetséges útjait foglalja össze a 11. ábra.

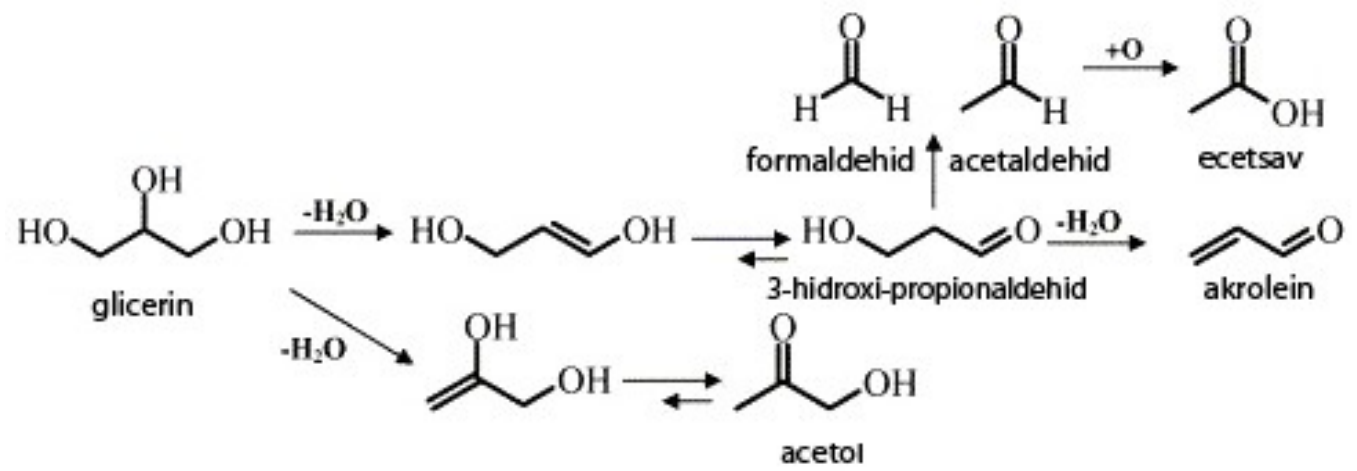

11. ábra: Glicerin dehidratációja [63]

Ha a szekunder $\mathrm{OH}$-csoport protonálódik, akkor az átmeneti termék egy víz és egy $\mathrm{H}^{+}$ eltávozásával és tautomerizációval instabilis 3-hidroxi-propionaldehiddé (3-HPA) alakul, ami tovább dehidratálódik akroleinné $[63,64]$, vagy bomlik CO-t, formaldehidet és/vagy acetal- 
dehidet eredményezve [63-65].

Ellenben, ha a protonálódás a terminális hidroxilcsoporton történik, deprotonálódással, dehidratálódással és tautomerizációval hidroxi-aceton (acetol) lesz a termék [63, 64, 66], ami kevésbé reaktív, de megfelelö körülmények közt továbbalakulhat.

Néhány lehetséges dehidratációs terméket mutat be a 12. ábra.

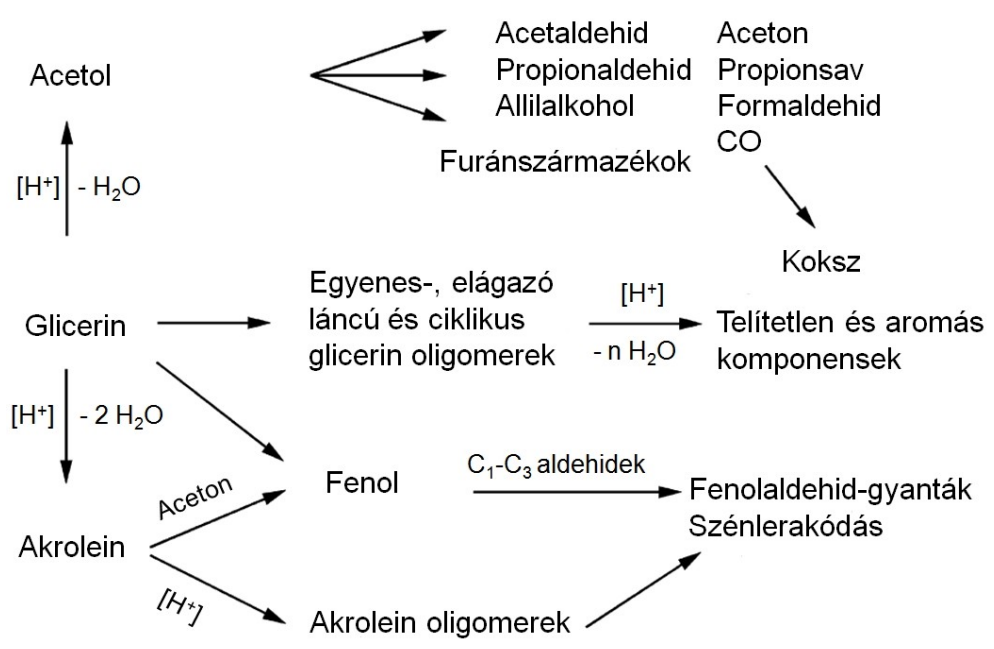

12. ábra: Glicerin dehidratációjának általános sémája [64]

Az akrolein használható akrilsav, akrilgyanta [67] nyersanyagaként, szuperabszorbensek, polimerek és detergensek gyártására [68] a gyógyszeriparban, akrilszálak gyártására, utókezelésére, stb. Mai előállítása a kőolajból származó propilén szelektív oxidációjával történik [63].

Bár a biodízelgyártás során nyert nyers glicerin tisztasága az általában használt eljárásokkal 90 tömeg\% fölé emelhető, a kísérletek azt bizonyították, hogy az akrolein glicerinből való előállításának a víz jelenléte még kedvez is. Erre a célra tehát a nyers glicerin víztelenítés nélkül közvetlenül felhasználható, ehhez viszont víznek ellenálló katalizátor szükséges [64, 69, 70].

Az acetolt alkalmazzák aromaként az élelmiszeriparban, textilfestékként, bőrbarnítókhoz a kozmetikai iparban, valamint kiindulási alapot biztosít a propilénglikol, akrolein, propionaldehid, aceton és furánszármazékok szintéziséhez [71].

Folyadék- vagy - hatékonyabb módon - gőzfázisban [63, 64, 69, 70, 72], vagy nagy nyomású, magas hőmérsékletủ vízben (hot-compressed water, $H C W$ ) [73-76] kettős dehidratáció mehet végbe. Bühler és munkatársai szerint adalékok nélkül, szuperkritikus $\left(349-475{ }^{\circ} \mathrm{C} ; 25\right.$, 35 és $45 \mathrm{MPa}$ ) körülmények közt a glicerin (víz:glicerin = 199:1) átalakulhat - kompetitív módon - gyökös és ionos folyamatokon keresztül is (13. ábra). Ha a hömérséklet csökken vagy a nyomás nő, akkor ionos dehidratációval akrolein keletkezik, valamint nő az ionosan 
keletkező acetaldehid és formaldehid aránya. Az ionos reakcióút legfontosabb lépése a glicerin protonálódása, amely föleg a víz öndisszociációjának következtében valósulhat meg. Ha azonban a hőmérséklet nő, vagy a nyomás csökken, gyökös dehidratációval allilalkohol, kötéshasadással acetaldehid és formaldehid, valamint metanol és gázok képződnek [75].
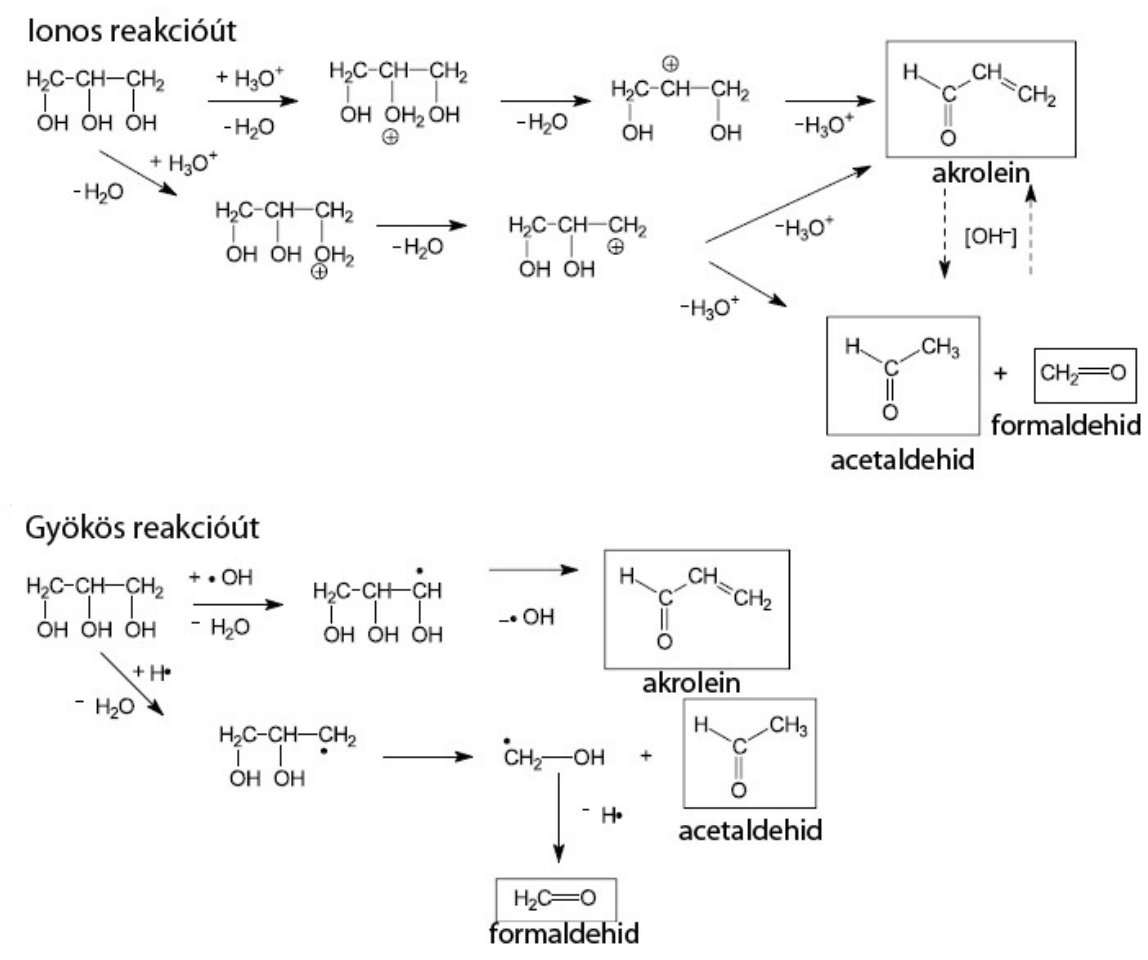

13. ábra: Akrolein, acetaldehid és formaldehid ionos és gyökös úton való keletkezése [75]

Egyéb, magas hőmérsékleten és nyomáson (HCW: 300-400 $\left.{ }^{\circ} \mathrm{C}, 25-34,5 \mathrm{MPa}\right)$ végzett kutatások megerősítették azt az elképzelést, hogy a glicerin-akrolein átalakulás ionos formák (pl. protonok) által szabályozott, melyek mennyisége növelhető savak, sók [73, 74, 76] és katalizátor alkalmazásával. Ilyen savak vagy sók lehetnek például a $\mathrm{H}_{2} \mathrm{SO}_{4}[73,74]$ és a $\mathrm{ZnSO}_{4}$ [76]. A fóbb melléktermékek $350^{\circ} \mathrm{C}$-on az acetaldehid és hidroxi-aceton volt, míg magasabb hőmérsékleten $\left(400{ }^{\circ} \mathrm{C}\right)$ az acetaldehid, formaldehid és allilalkohol [74] váltak meghatározóvá.

A legelterjedtebben használt katalizátorok a természetes és mesterséges eredetű szilíciumtartalmú anyagok: savas zeolitok [70] és savas, szulfáttal, foszfáttal [64, 72], volframáttal [72], molibdenáttal [72], heteropolisavakkal [63] impregnált oxidok $\left(\mathrm{TiO}_{2}, \mathrm{Al}_{2} \mathrm{O}_{3}, \mathrm{ZrO}_{2}\right)$ [63, $65,77]$. Ezek hátránya, hogy sok melléktermék képződik, és a katalizátor kokszképződés következtében dezaktiválódik $[65,66,69]$. A kokszolódás megszüntetése levegő $\left(\mathrm{O}_{2}\right)$ áramban történő hökezeléssel történhet, ezért a víztolerancia mellett fontos a termikus stabilitás is. 
A lejátszódó folyamatok mechanizmusa többek között a hőmérséklettől, nyomástól, víztartalomtól, pórusmérettől és a savasságtól függ.

Glicerin dehidratációjában a mezopórusos $\mathrm{Al}_{2} \mathrm{O}_{3}-\mathrm{PO}_{4}$ és $\mathrm{TiO}_{2}-\mathrm{PO}_{4}$ impregnált fém-oxidok teljes felülete hozzáférhető a reakciók számára, így aktívabbak, de akroleinre kevésbé szelektívek. Ezzel szemben a szük pórusú és nagy savasságú SAPO (szilícium-alumínium-foszfát) esetén a reakciók a külső felületen mennek végbe, így az kevésbé aktív, de akroleinre szelektívebb. A katalizátor kokszolódik, dezaktiválódik, azonban $450{ }^{\circ} \mathrm{C}$-on levegőáramban regenerálható. A vizsgálatok azt mutatták, hogy savas katalizátor jelenlétében az acetol $240{ }^{\circ} \mathrm{C}$-ig stabilis, míg a 3-HPA már $120{ }^{\circ} \mathrm{C}$-on akroleinné dehidratálódik, vagy ciklikus $\mathrm{C}_{6}$-komponensekké kondenzálódik [64].

Környezeti hőmérsékleten és nyomáson az erősen savas centrumokat tartalmazó, viszonylag nagy $(\mathrm{d}=10 \mathrm{~nm})$ pórusmérettel rendelkező és termostabilis $\mathrm{SiO}_{2}$ hordozós szilikovolframsav [63], illetve az amorf és víztoleráns $\mathrm{Nb}_{2} \mathrm{O}_{5}$ jelenlétében is kedvező akroleinszelektivitást (85\% ill. $51 \%$ ) értek el híg (10, ill. 36,2 tömeg\%) vizes oldat esetén. Utóbbi esetben a dezaktiválódott katalizátor magas hőmérsékletü oxidációval regenerálható volt [69].

$\mathrm{A} \mathrm{FePO}_{4}$ teljes átalakulás mellett $92 \%$ akroleinszelektivitást eredményezett 40 tömeg\%-os glicerinoldat dehidratációjában. A katalizátor a használat során itt is dezaktiválódik, ami a reakcióút, és így a termékeloszlás megváltozásához vezet. Oxigén hozzáadásával a kokszképződés csökkenthető, azonban csökken az acetol és akrolein aránya is az acetaldehid, az ecetsav és a $\mathrm{CO}_{\mathrm{x}}$ javára. Megfelelően kialakított molibdén/volfrám/vanádium-alapú katalizátor jelenlétében glicerinből közvetlen oxi-dehidratációval akrilsav állítható elő, ami az akrilát típusú mủanyagok gyártásának egyik fontos nyersanyaga [72].

Atmoszférikus nyomáson és $315^{\circ} \mathrm{C}$ hömérsékleten tesztelt zeolitokkal kapcsolatban megállapították, hogy a glicerin átalakulásában a katalizátor savassága meghatározó. Az akrolein képződésében a Brønsted savas helyeknek kitüntetett szerepük van. Egyéb paraméterek, mint a katalizátor hidrofóbicitása, felülete, pórusmérete szintén jelentős befolyásoló tényezők [70, 78]. Erről bővebb leírás a 2.5.1.1. fejezetben olvasható.

$\mathrm{Az} \mathrm{Al}_{2} \mathrm{O}_{3}$ hordozós $\mathrm{Cu}$-katalizátoron $250{ }^{\circ} \mathrm{C}$-on és környezeti nyomáson teljes átalakulás mellett 90 mol\% feletti acetolszelektivitást értek el. A sav hatását a már mások [63, 67, 79] által is leírt (lásd ennek a fejezetnek az elején) módon értelmezték, míg a Cu szerepét a következőképp írták le: a glicerin primer OH-csoportjából származó OH-gyök összekapcsolódik a $\mathrm{Cu}$-alkoxidból származó H-gyökkel, $\mathrm{H}_{2} \mathrm{O}$-t alkotva, és acetolt hozva létre. $\mathrm{A} \mathrm{Cu} / \mathrm{Al}_{2} \mathrm{O}_{3}$ esetén a Cu és a sav hatása együttesen érvényesül [67]. 
Az akrolein előállítását célzó kutatásokban sokszor nagyon híg vizes glicerinoldatot használnak, ami egyszerre viszonylag kevés glicerin átalakulását teszi lehetővé, viszont nagy a víz- és energiaigénye. Ezzel szemben a hidroxi-aceton előállításához nem szükséges a nagy víztartalom, sőt nagytisztaságú (99,9\%) glicerint is sikerült $90 \%$-os szelektivitással acetollá dehidratálni $240{ }^{\circ} \mathrm{C}$-on és $98 \mathrm{kPa}$ nyomáson, réz-kromit-katalizátor jelenlétében. A réz növeli az aktivitást, de könnyen szintereződik, így a szerkezetbe krómot vittek, hogy stabilizálja azt [80]. Ez a tanulmány képezte az egyik kiindulási alapot kísérleteimhez.

\subsubsection{A glicerin hidrogenolízise}

Mivel a glicerinben nagy az $\mathrm{O} / \mathrm{C}$ arány, ezért vonzó lehetőség a hidrogenolízis, melynek során hidrogén jelenlétében megvalósított reakcióval előállítható termékeket a 14 . ábra szemlélteti. Ezek közül a legértékesebbek a propándiolok [81].

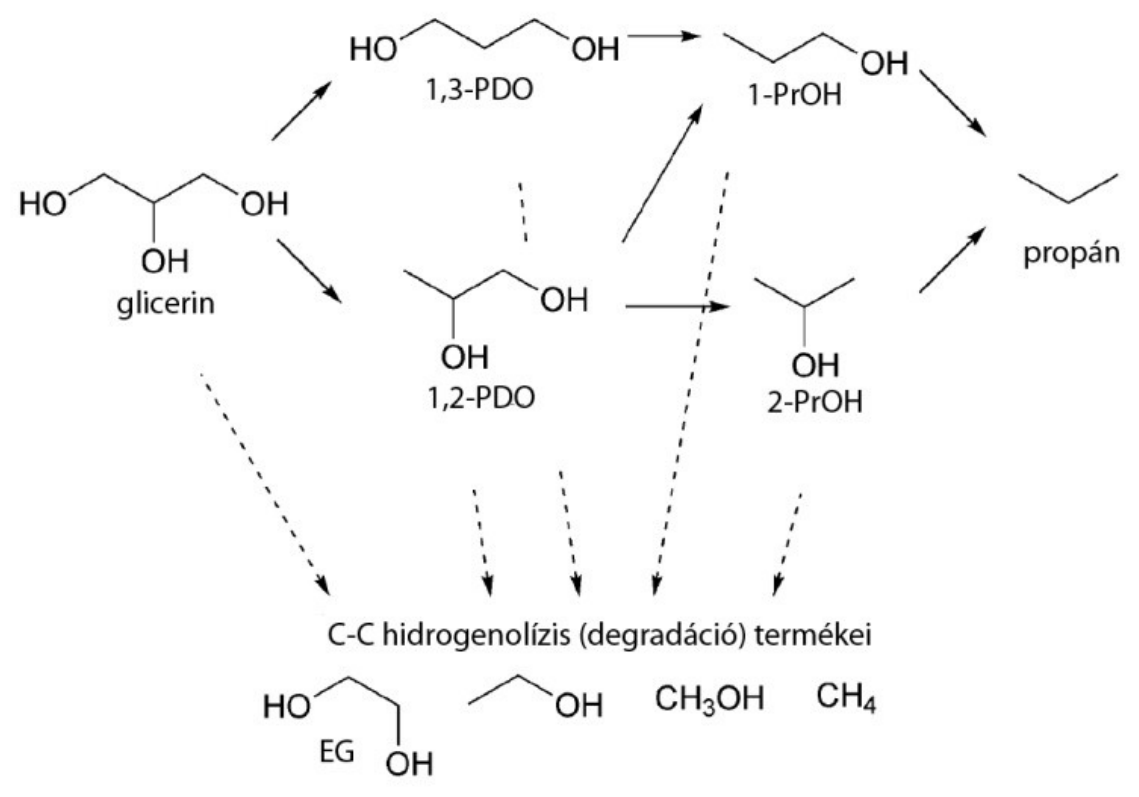

14. ábra: Glicerin hidrogenolízise [81]

1,2-propándiol (propilénglikol, 1,2-PDO) 1,3-propándiol (1,3-PDO), 1-propanol (1-PrOH), 2-propanol (2-PrOH), etilénglikol (EG)

A propilénglikolt legelterjedtebben a következő területeken alkalmazzák: telítetlen poliészter gyanták előállítása, nedvesítő szerek, fékfolyadék, folyékony detergensek, fagyálló folyadék, jégmentesítőszer és hőátadó/hütő közeg. Használják ezenkívül a gyógyszer-, élelmiszer- és kozmetikai iparban, dohány aromatizáló szerként, aroma- és illatanyagként, valamint festék és állateledel gyártásában is [82-84].

Az 1,3-PDO-t tereftálsavval kopolimerizálva olyan poliésztert lehet előállítani, amely szőnyeg és textilszálak gyártásához használható $[85,86]$, valamint alkalmazzák poliuretánok 
és ciklikus komponensek létrehozásában is [87, 88].

Mai gyártásuk petrolkémiai úton történik [83]. Fermentációval ugyan 70 \% feletti 1,3-PDO hozamot sikerült elérni, de a folyamat nagyon időigényes [68].

Elöállításukra környezetbarát alternatívát jelenthet a glicerin katalitikus hidrogenolízise. A reakciómechanizmust többek között befolyásolja a $\mathrm{pH}$, a katalizátor természete (nemesfém/ átmeneti fém), szemcsemérete, az alkalmazott hőmérséklet és nyomás, stb.

Semleges (vagy lúgos) közegben a glicerin glicerinaldehiddé dehidrogéneződik, majd az dehidratálódik 2-hidroxi-akroleinné, mely végül 1,2-PDO-lá hidrogéneződik [89-91]. Nemesfém-katalizátorokon általában ez a háromlépéses reakció (15. ábra) [92] megy végbe, de nagy hatékonyságot értek el például $\mathrm{Cu} / \mathrm{MgO}$ esetében is $\mathrm{NaOH}$ hozzáadásával [93].

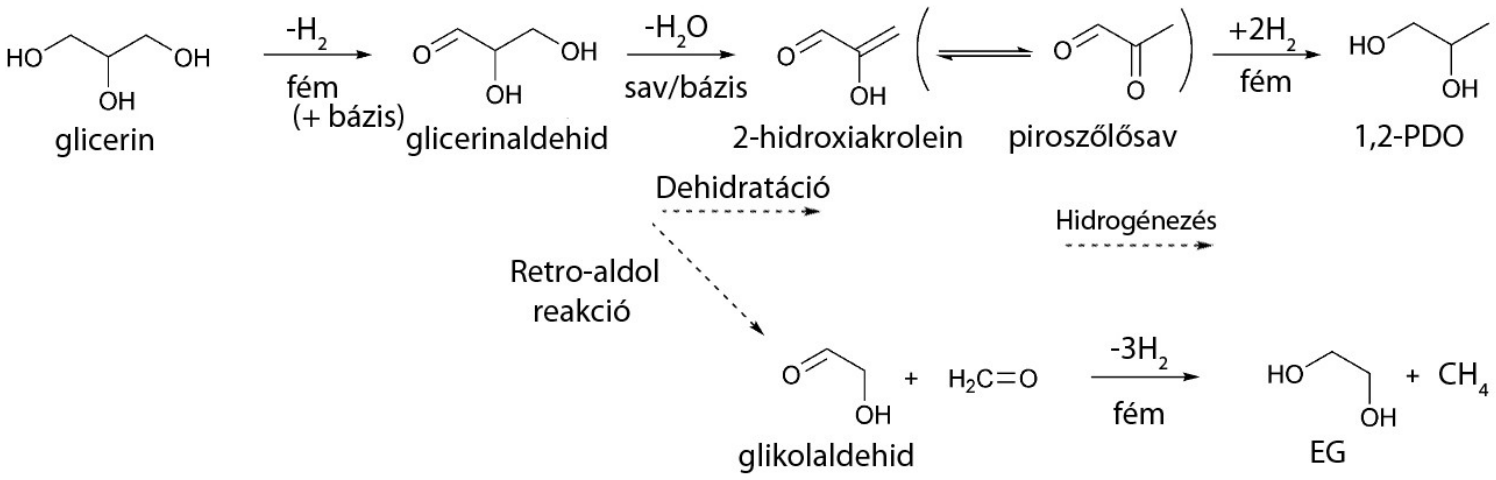

15. ábra: Glicerin háromlépéses hidrogenolízise semleges/lúgos környezetben [81]

Nemcsak bázis hozzáadásával, de olyan bifunkciós katalizátorok használatával is nyerhetünk propilénglikolt, amelyek tartalmaznak fémes és bázikus helyet is, mint például a hidrotalcit-, vagy MgO hordozóra vitt Pt [94]. Ezek azért is említésre méltó katalizátorok, mert környezetbarátak, valamint könnyü őket elválasztani és visszaforgatni [93].

Maris és Davis vizsgálatai szerint semleges $\mathrm{pH}-\mathrm{n}$ a $\mathrm{Ru} / \mathrm{C}$ aktívabb ugyan, mint a $\mathrm{Pt} / \mathrm{C}$, viszont propilénglikol-szelektivitásban a platina a jobb. Lúg hozzáadásával mindkettő aktivitása növelhető (100\% konverzió), de ezzel együtt a melléktermékként keletkező laktát aránya is nő. A Ru/C 50 \% konverzió mellett 46 \% 1,2-PDO-szelektivitást eredményezett, míg a Pt/C $40 \%$ átalakulás mellett $71 \%$ propilénglikol-képződést segített elő [90]. Kétfémes PtRu/C és $\mathrm{AuRu} / \mathrm{C}$ semleges $\mathrm{pH}-\mathrm{n}$ az etilénglikol keletkezését segítette elő, míg bázis jelenlétében a laktát és a propilénglikol szelektivitása nőtt 40-50\% glicerinkonverzió mellett [91] (reakciókörülmények: $220^{\circ} \mathrm{C} ; 4 \mathrm{MPa} \mathrm{H}_{2} ; 1$ tömeg\% -os glicerin vizes oldat).

Enyhébb körülmények közt a $\mathrm{Rh} / \mathrm{SiO}_{2}$ sokkal aktívabbnak és szelektívebbnek mutatkozott a Ru/C-nél. A folyamat mechanizmusa azonban eltért az előzőektől [95]. 
A másik lehetséges reakcióút a dehidratálás-hidrogénezés kombinációja, amely savas környezetben megy végbe. A glicerin dehidratációval a sav jelenlétének köszönhetően acetollá, vagy 3-hidroxi-propionaldehiden (3-HPA) át akroleinné alakul [63, 69, 73, 74, 76, 80, 96], melyek hidrogénnyomás alatt a fémes helyeken továbbhidrogénezve 1,2-, ill. 1,3-propándiollá konvertálhatók (16. ábra). Szervetlen savakat, pl. $\mathrm{H}_{2} \mathrm{WO}_{4}$ [83], vagy ioncserélő gyantákat (Amberlyst-15, Amberlyst-70) [97-100] adva a reakcióelegyhez, esetleg savas hordozót (savas heteropolisav sója) alkalmazva [101] a kezdeti dehidratációs lépés előmozdítható.

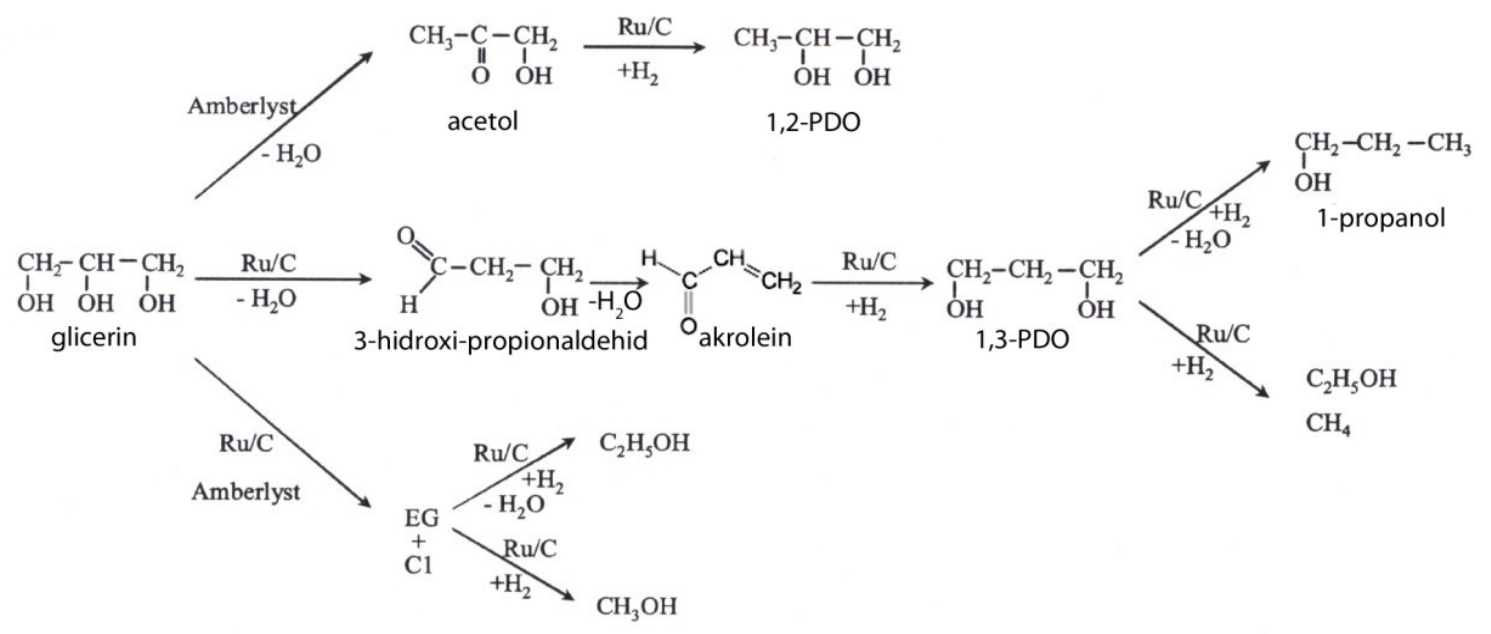

16. ábra: Glicerin kétlépeses hidrogenolízise savas környezetben [98]

A glicerin és az akrolein (vagy 3-HPA) reakciójából illetve az 1,3-PDO-ból kondenzációval (diolok+aldehidek) ciklikus acetálok képződnek. Ezek az egyik legfőbb melléktermékcsoportja a fémes-savas bifunkciós katalizátoron történő gőzfázisú hidrogenolízisnek [102].

A nemesfém-katalizátorok általában aktívabbak a hidrogenolízisben, mint az átmenetifémalapúak, de a propándiol-szelektivitásuk - feltehetően a rendkívül nagyarányú $\mathrm{C}-\mathrm{C}$ kötéshasítás miatt - alacsonyabb [83, 84, 92, 97, 103, 104]. A Cu-tartalmú minták ezzel szemben gyenge aktivitást mutatnak a $\mathrm{C}-\mathrm{C}$ kötések hasításában, így viszonylag kevés melléktermék képződik, s mivel jó C-O kötés hidro-dehidrogénezők [102, 103], jó szelektivitást lehet velük elérni propándiolokra [105]. Ezek azonban általában nem elég aktívak, ezért nagy katalizátor-glicerin arányt kell alkalmazni. A minták előállítási módjának és a reakció körülményeinek optimalizálásával a felület, az aktív részek diszpergáltsága, és így az aktivitás is növelhető [105].

Vízgőzös reformálással, nagy nyomású autoklávban Pt/NaY-katalizátor jelenlétében sikerült megvalósítani a glicerin in situ propilénglikollá alakítását $[82,106]$. A glicerin dehidratációja acetollá valószínűleg Brønsted-savval katalizált folyamat [80, 84]. Impregnált Pt/NaY esetén a nagy Pt részecskék a vázon kívül helyezkednek el, a katalizátor nem savas, viszont a 
reformálás során keletkező $\mathrm{CO}_{2}$ a vizes reakcióközegben oldódva $\mathrm{H}_{2} \mathrm{CO}_{3}$-t hoz létre, amely disszociálva szabad protonokat eredményez. Ezek a $\mathrm{Na}^{+}$-ionokkal részben kicserélődnek, savassá téve a zeolitot, és így a glicerin-acetol dehidratáció megvalósulhat. A további hidrogéneződés a rácsba be nem épült platinarészecskéken történik. Ha a Pt-NaY-katalizátort ioncserével készítették, a Pt beépült a rácsba, és az így létrejött savcentrumokat tartalmazó katalizátor több krakktermék és kevesebb propándiol képződését eredményezte [82, 106].

Az átmenetifémek szintén képesek aktiválni a $\mathrm{H}_{2}$ molekulákat. Hidrogénező aktivitásuk ugyan kisebb, de olcsóbbak és a mérgeződésnek is jobban ellenállnak [81]. Leggyakrabban a rezet használják, melynek nagy az 1,2-PDO-szelektivitása, de olvashatunk még az irodalomban Ni [88, 107, 108] és Co [109] alkalmazásáról is.

Glicerin gőzfázisú dehidratációját hidrogénáramban végezve $\mathrm{Al}_{2} \mathrm{O}_{3}$ hordozóra vitt réz jelenlétében az acetol mellett 1,2-PDO megjelenését tapasztalták [67].

Másoknak $\mathrm{Cu} / \mathrm{Al}_{2} \mathrm{O}_{3}$-katalizátorral 49,6 \% konverziót és 96,8 \% propándiol-szelektivitást sikerült elérni [105].

$\mathrm{CuO} / \mathrm{ZnO}$ jelenléte közel 100 \% 1,2-PDO-szelektivitást biztosított, de az aktivitás túlzottan alacsony, szakaszos reaktorban 90 óra elteltével is csupán $19 \%$ volt [83].

Ezzel szemben $\mathrm{Cu}-\mathrm{ZnO}$ használatával enyhébb körülmények közt sokkal kevesebb idő alatt nagyobb konverzió mellett hasonló szelektivitást (200 $\left.{ }^{\circ} \mathrm{C} 4,2 \mathrm{MPa}\right)$ tapasztaltak [110].

Réz-kromit szerepét vizsgálták glicerin propilénglikollá történő hidrogenolízisében a korábbiaknál jóval alacsonyabb [84], illetve atmoszférikus nyomáson [111]. Utóbbi esetben 240 ${ }^{\circ} \mathrm{C}$ hőmérsékleten He-atmoszférában akrolein képződését tapasztalták. Hidrogén jelenlétében kezdetben 1,2-PDO volt a fö termék, ami a reakcióidő növekedésével folyamatosan csökkent, és ezzel párhuzamosan az acetol hozama nőtt [111]. Suppes és társai a kétlépéses hidrogenolízist enyhe körülmények között $\left(200{ }^{\circ} \mathrm{C}, 1,4 \mathrm{MPa} \mathrm{H}\right.$, 24 h) 55 \%-os konverzió mellett $85 \%$ propilénglikol-szelektivitással valósították meg [84].

Megállapítható, hogy a propilénglikol az acetol réz-kromiton való hidrogénezésével alakul ki. Ehhez az szükséges, hogy a katalizátor felületén aktív hidrogén legyen [84, 111].

$\mathrm{Cu}-\mathrm{H}_{4} \mathrm{SiW}_{12} \mathrm{O}_{40} / \mathrm{Al}_{2} \mathrm{O}_{3}$ (Cu-STA)-katalizátorral glicerin vizes oldatából $90 \%$ körüli konverzióval és szelektivitással sikerült 1,2-PDO-t nyerni, úgy hogy a teljesítménye 250 órán át nem csökkent [112]. Az STA-tartalom (szilikovolfamsav, $\mathrm{H}_{4} \mathrm{SiW}_{12} \mathrm{O}_{40}$ )emelése kezdetben növeli, majd - a túl sok savas hely következtében - csökkenti a konverziót [112]. A savas helyeken végbemenő dehidratációt követően a fémes helyeken történik a hidrogénezés [84, 98, $112]$. 
Gőzfázisú hidrogenolízisben alkalmazva $\mathrm{SiO}_{2}$ hordozóra vitt Cu-STA-t acetolon keresztül 1,2-, míg 3-HPA-en át 1,3-PDO vagy akrolein keletkezett. A reakciókörülményeket optimalizálva $\left(210{ }^{\circ} \mathrm{C}, 0,54 \mathrm{MPa}\right)$ 83,4 \% konverzió mellett 1,3-PDO-ra 32,1\% szelektivitást, míg 1,3- + 1,2-PDO-ra 54,3\% kombinált szelektivitást sikerült elérni [102].

Enyhe körülmények között Raney-Ni-katalizátoron $63 \%$ glicerinkonverzió mellett 20 óra alatt 77 \% 1,2-PDO-szelektivitást produkáltak, és 44 óra elteltével az átalakulást 97 \%-ra növelték. Ha nem használtak oldószert, a termék könnyen elválasztható volt desztillációval, míg folyékony foszfónium só alkalmazásával a szelektivitás ugyan nőtt, de az elválasztás problémákba ütközött. Melléktermékként kizárólag $\mathrm{CO}_{2}$ és etanol képződését tapasztalták [88].

Az eddig bemutatott eljárások vizes közegben zajlottak, és főképp 1,2-PDO keletkezését tűzték ki célul. A kutatások azt mutatják, hogy a hatékony glicerin-1,3-PDO átalakuláshoz általában szükséges valamilyen szilárd sav $\left(\mathrm{pl}\right.$. $\left.\mathrm{WO}_{4}\right)$, nemesfém és aprotikus poláris oldószer (pl. szulfolán, 1,3-dimetil-2-imidazolidinon /DMI/) [113].

Szulfolánban homogén Ru-katalizátorral [114] vagy $\mathrm{Rh} / \mathrm{C}$ és $\mathrm{H}_{2} \mathrm{WO}_{4}$ adalék jelenlétében [83] magas nyomáson (5-8 MPa) sikerült 1,3-PDO-t előállítani, de csak 3-4 \%-os hozammal.

Impregnált $\mathrm{Pt} / \mathrm{WO}_{3} / \mathrm{ZrO}_{2}$ jelenlétében, autoklávban $8 \mathrm{MPa}$ kezdeti $\mathrm{H}_{2}$-nyomáson, $160{ }^{\circ} \mathrm{C}$ on DMI oldószerben Kurosaka és munkatársai 24,2 \% 1,3-PDO-hozamot értek el, ami a propilénglikol hozamának kétszerese volt [113].

\subsection{A reaktív desztilláció}

Hagyományos esetben egymástól elkülönítetten zajlik a reaktorban a reakció, majd ezt követi elválasztási műveletként a desztilláció. A reaktív desztilláció ezzel szemben egy olyan többfunkciós eljárás, ahol a két folyamat egy időben történik, ugyanabban a reakciótérben. Ez számos előnnyel jár. Az egymást erősítő hatások jóvoltából át lehet lépni kémiai reakciók termodinamikai korlátait, s azzal, hogy a terméket gyorsan eltávolítjuk a reakcióelegyből, megakadályozhatjuk annak továbbalakulását, ezáltal növelhetjük a szelektivitást. A reakció exoterm hőjét használva reagáltathatjuk a hagyományos desztillációban jelenlévő azeotrópokat, megakadályozva a „hot spot”-ok kialakulását. Ezen túl alacsonyabb beruházási és müködtetési költséget jelentenek, és környezetkárosító hatásuk is kisebb [115].

Az előzőekben bemutatott propilénglikol előállítására használt eljárások általában nagy nyomást és hömérsékletet igényelnek, valamint nagyon híg (akár 1-2 tömeg\%) glicerinoldat alkalmazásával is sokszor alacsony volt a hatásfok. Két lépésben azonban nagy szelektivitást lehet elérni acetol köztiterméken keresztül. A glicerint reaktív desztillációs technikával 98 $\mathrm{kPa}$ nyomáson és $240{ }^{\circ} \mathrm{C}$-on acetollá lehet dehidratálni. Mivel az acetol sokkal illékonyabb a 
glicerinnél, így a gőzzel a víz és az acetol eltávozik, ezáltal csökken az acetol degradációjának lehetősége, és a katalizátortól való elválasztás is könnyen megtörténik. Ez az irodalmi előzmény szolgáltatta kísérleteim egyik alapját, ahol 99,9 \% tisztaságú glicerint alkalmaztak szakaszos és félfolyamatos rendszerü reaktív desztillációban [80].

Chiu és munkatársai [80] vizsgálataikban folyamatosan kevert üvegreaktorhoz visszafolyós hütőt csatlakoztattak, és állandó hőmérsékletü olajfürdőbe rakták. A reaktorba tett katalizátort a reakció hőmérsékletére $\left(240{ }^{\circ} \mathrm{C}\right)$ fütötték, majd beletöltötték a glicerint, illetve a félfolyamatos üzemben a glicerint egy perisztaltikus szivattyú segítségével folyamatosan táplálták be. A ruténium használata esetén a szelektivitás alacsony, a visszamaradó desztillációs maradék aránya magas volt, valamint a polimerizációs-kondenzációs folyamatok további dezaktiválódáshoz vezettek. Nikkel és palládium esetén kevés volt a desztillációs maradék, ugyanis ezek a fémek túl aktívak voltak, így a reakció kis molekulatömegü alkoholokat és gázokat eredményezett. A réztartalmú minták acetolszelektivitásban és a maradékot tekintve is felülmúlták a többi katalizátort. A réz aktív, de szintereződésre hajlamos, amire a króm, mint stabilizátor szerkezetbe vitele jelentett megoldást. A réz-kromittal $90 \%$ feletti konverziót és acetolszelektivitást értek el. Érdekes módon propilénglikol keletkezését is tapasztalták, bár az egyedüli hidrogénforrás egy másik glicerin vagy acetol molekula lehetett.

A reakciót „időben leállítva” a katalizátorról a zagyszerű maradékot metanolos mosással el tudták távolítani, és a katalizátor újra felhasználva az aktivitásából és szelektivitásából alig veszített [80].

\subsection{Az alkalmazott katalizátorok jellemzése}

\subsubsection{Zeolitok}

A zeolitok alkáli- és/vagy alkáliföldfémek ( $\mathrm{Na}, \mathrm{K}, \mathrm{Mg}$ és $\mathrm{Ca}$ ) kristályos alumínium-hidroszilikátjai. Vázuk háromdimenziós, melyet a közös oxigénatomokon keresztül kapcsolódó $\mathrm{TO}_{4}$-tetraéderek alkotják, ahol a tetraéderes koordinációban lévő T-atomok/ionok, $\mathrm{Si}^{4+}$ vagy az őket izomorf módon helyettesítő $\mathrm{Al}^{3+}$. Ezzel a kapcsolódással olyan molekuláris méretű üregek és csatornák alakulnak ki, melyek együttesen szabályos rendben elhelyezkedő elemi cellák sorozatát hozzák létre [116].

Abban az esetben, ha a T-atom/ion $\mathrm{Al}^{3+}$, a rács negatív töltését a szomszédságában elhelyezkedő ötértékủ tetraéderes atom/ion (például $\mathrm{P}^{5+}$ az alumínium-foszfátban), vagy valamilyen kation kompenzálja, ezáltal kationcserélő tulajdonságot kölcsönözve a zeolitnak. A kristályos szerkezet (üregek és csatornák) tartalmazhat még vizet vagy szerves molekulákat (vagy 
sókat). Ezeket hőkezeléssel eltávolítva pórusos szerkezetet kapunk, ami a zeolitok adszorpciós tulajdonságaiért felelős [117-119].

A zeolitok általános összetétele egy elemi cellára vonatkozóan a következőképpen adható meg:

$$
\left(\mathrm{Me}^{n+}\right)_{x / n}\left[\left(\mathrm{AlO}_{2}\right)^{-}{ }_{x}\left(\mathrm{SiO}_{2}\right)_{y}\right] \cdot w \mathrm{H}_{2} \mathrm{O}
$$

ahol Me: a kation;

$n$ : a kation töltése;

w: a vízmolekulák száma;

$x / y$ arány: szerkezettől függően általában 1-5;

$(x+y)$ összeg: az elemi cella tetraédereinek összege [116].

A Si/Al arány (modulus) meghatározó a stabilitás, aktivitás, savasság és pórusméret, ezzel összefüggésben a katalitikus és adszorpciós tulajdonságok szempontjából.

A zeolitok katalitikus tulajdonságai könnyen módosíthatók például úgy, hogy szerkezetükbe jól diszpergált fémrészecskéket lépítenek, amivel hatékonyságuk növelhető. Továbbá említést érdemelnek még sav-bázis tulajdonságaik és alakszelektív mivoltuk.

Hátrányukként róható fel, hogy a hőkezelés során a redukálódott fémkomponensek a zeolit külső felülete felé vándorolhatnak, így csökkenhet az adott reakcióra az alakszelektivitás. Az agglomerált fém pedig kitöltheti a pórusrendszert, ami blokkolhatja a zeolitszerkezetet, és a pórusokban diffúziógátlás léphet fel.

\subsubsection{A ZSM-5 szerkezete, tulajdonságai és alkalmazása}

A ZSM-5 (MFI) szerkezetü, nagy $\mathrm{SiO}_{2}$-tartalmú zeolitot először az 1960-as években szintetizálta Argauer és Landolt, majd a Mobil Oil Corporation szabadalmaztatta 1972-ben [120].

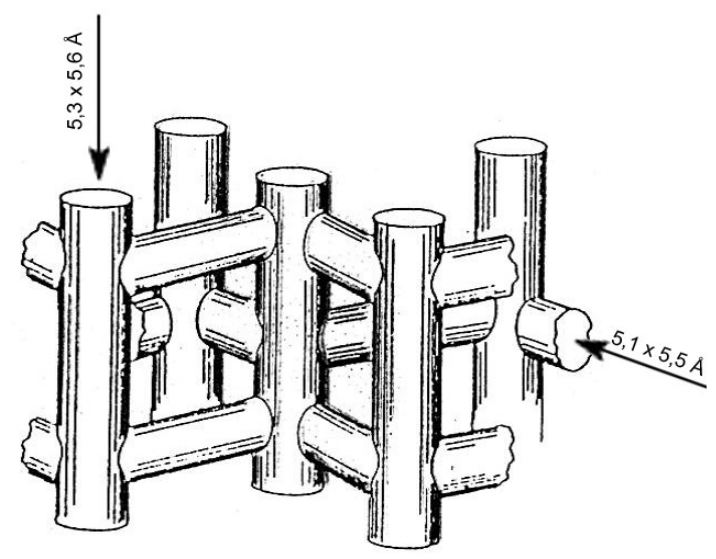

17. ábra: ZSM-5 egyenes és cikk-cakkos csatornái 
Közepes pórusméretü zeolit, háromdimenziós csatornarendszerét (17. ábra) 10-tagú gyürük alkotják. A közel kör alakú, egymásra merőleges elliptikus csatornák keresztmetszeteinek mérete - (010) irányban - 5,3 × 5,6 $\AA$, illetve - (100) irányban - 5,1 × 5,5 $\AA$ [121]. Szerkezetét és a csatornák keresztmetszeteit a 18. ábra és a 19. ábra mutatja.
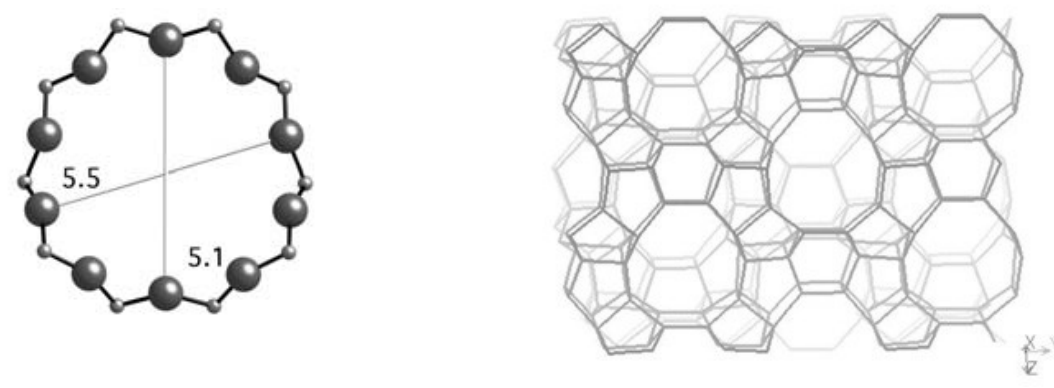

18. ábra: 10-tagú gyürủ az (100) irányból $[122,123]$
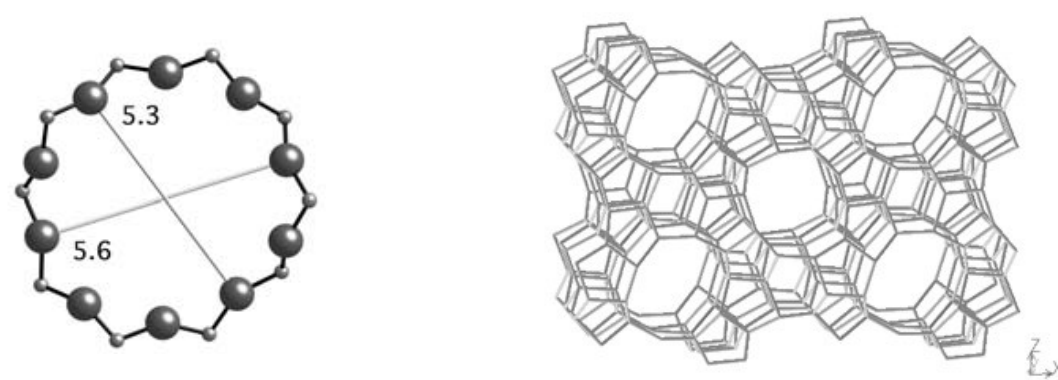

19. ábra: 10-tagú gyürủ a (010) irányból [122, 123]

A ZSM-5 zeolit jól meghatározott szerkezetéböl adódóan alakszelektív, és kis alumíniumtartalmának köszönhetően nagy hőstabilitással rendelkezik. A szilikátvázon belüli alumínium $\mathrm{Si}-(\mathrm{OH})-\mathrm{Al}$ egységeket alkot, melyek erős Brønsted-savasságot eredményeznek [124]. Ezek miatt, valamint ioncserélő tulajdonságának, pórusméretének, és szerkezetének köszönhetően széles körben használják mint alakszelektív adszorbenst és katalizátort a petrolkémiában [125-128]. Alkalmazzák szénhidrogén-krakkolásban és -izomerizációban [129], metanol benzinné konvertálásában (MTG), kis molekulatömegü olefinek és alkánok ciklooligomerizációjában és aromásokká történő átalakításában (Cyclar-eljárás) [130].

Leggyakrabban hidrotermális úton állítják elő gélből, amely tartalmaz alumínium- és szilíciumforrást és valamilyen templátot, amely az irányított kristályosodást segíti elő. Ilyen szerves komponens lehet a tetrapropilammónium-bromid, a tetrapropilammónium-hidroxid [117], a tripropilamin vagy a dipropilamin [131]. Költséghatékony megoldást találtak etanol [132], mint templát alkalmazásával, illetve sikerült ZSM-5-öt létrehozni szerves templát használata nélkül is, például a kereskedelmi forgalomban elérhető $\beta$ és Y zeolitot használva Si- és Al- 
forrásként. Utóbbi esetben a zeolitot $\mathrm{NaOH}$-oldattal reagáltatva, majd hidrotermális körülmények közé helyezve kristályosodik ki a ZSM-5 szerkezetü termék [133].

A ZSM-5 elemi cella összetétele Na-forma esetén:

$$
\mathrm{Na}_{\mathrm{n}} \mathrm{Al}_{\mathrm{n}} \mathrm{Si}_{96-\mathrm{n}} \mathrm{O}_{192} \cdot 16 \cdot \mathrm{H}_{2} \mathrm{O} \quad \text { ahol } \mathrm{n} \leq 27
$$

A „,nyers” (,,as-prepared”) mintákat kalcinálják, és legtöbbször ammónium-kloriddal/-nitráttal ioncserélik. $\mathrm{Az} \mathrm{NH}_{4}{ }^{+}$-formát szintén hevítik levegőben, hogy létrejöjjön a proton forma $[133,134]$.

A zeolitok szerkezetébe különböző technikával (ioncserével, impregnálással, izomorf szubsztitúcióval) juttathatunk be fémeket. Ioncserével csak kationokat, impregnálással ekvivalens mennyiségü anionokat is be lehet építeni. Izomorf szubsztitúcióval a Si-tól eltérő vázalkotó elemek, például háromértékủ kationok $\left(\mathrm{B}^{3+}, \mathrm{Al}^{3+}, \mathrm{Ga}^{3+}\right)$ rácsba juttatásával Brønstedsavas helyek, míg négyértékủ fémionok $\left(\mathrm{Ti}^{4+}, \mathrm{V}^{4+}, \mathrm{Sn}^{4+}, \mathrm{stb}\right.$.) felhasználásával redoxcentrumok alakíthatók ki. A beépítést minden esetben kalcinálásnak, illetve reduktív lépésnek kell követnie, hogy a vízmolekulák eltávozzanak, a fémionok pedig fémmé alakuljanak. Az aktivitást átmenetifém szennyeződések is biztosíthatják, amelyek sokszor csak néhány tizedszázalékban vannak jelen, de a felületen feldúsulva aktív helyként müködhetnek [135].

A kis kristályméretü zeolitok nagy külső felülettel rendelkeznek, és a kis diffúziós úthossz jelentős hatással lehet a reakció menetére és a termékeloszlásra. A morfológiát, a kristályméretet/méreteloszlást és a Si/Al-arányt a kiindulási kémiai összetétel [136], a szilícium- és alumíniumforrás mibenléte [137], a pH [138], a kristálygócok jelenléte [139], a hőmérséklet és a rendszer dinamikája [134] befolyásolják.

A zeolit aktív centrumainak elhelyezkedése nem függ szorosan a kristálymérettől. A nagy erősségü Brønsted-savcentrumokat a zeolit csatornáin belüli OH-csoportok alkotják, míg a Lewis-savas helyeket a külső felületen elhelyezkedő, gyengén savas szilanolcsoportok $(\mathrm{SiOH})$ képezik [124]. Katalitikusan aktív helyek nemcsak a csatornákban, a külső felszínen és a pórusok bejáratánál is vannak. Ezek tehetők felelőssé az alakszelektív reakciókban a nemkívánatos mellékreakciók lejátszódásáért [140].

Glicerin gázfázisú dehidratációjában sikeresen alkalmaztak Na-formájú és különböző modulusú HZSM-5 zeolitokat. A vizsgált minták közül a legjobb eredményt $\mathrm{SiO}_{2} / \mathrm{Al}_{2} \mathrm{O}_{3}=150$ arányú HZSM-5 jelenlétében érték el $315^{\circ} \mathrm{C}$-on, atmoszférikus nyomáson folyamatos müködésű állóágyas reaktorban [70].

Ugyanezen körülmények közt teszteltek különböző szerkezetü, hidrogénformájú zeolitokat (eltérő modulusú H-ferrieritet, H $\beta$-t, HZSM-5-öt, HY(FAU)-ot és H-mordenitet) is, és az 
eredményeket összehasonlították a $\gamma-\mathrm{Al}_{2} \mathrm{O}_{3}$ és amorf $\mathrm{SiO}_{2} / \mathrm{Al}_{2} \mathrm{O}_{3}$ esetén kapottakkal. A konverzió az utóbbi esetben volt a legmagasabb, míg a szelektivitásban a H-ferrierit mutatott kimagasló teljesítményt. A HZSM-5 ,a középmezőnyben végzett” [78].

A glicerin dehidratációjában a katalitikus aktivitást a felületi savasság [65] és az össz savasság [64] határozza meg.

A modulus növelésével (vagyis az alumíniumtartalom csökkenésével) párhuzamosan a savas helyek száma, valamint az adszorbeált víz mennyisége és annak kötéserőssége csökken. Ennek eredményeképp HZSM-5 esetén csökkent az acetaldehid, acetol és propionsav képzödése, és allilalkoholt, acetont, metanolt és etanolt is csak nyomokban tartalmazott a termékelegy [70, 78]. Megerősítést nyert az is, hogy a Brønsted-savas helyek sokkal inkább felelősek az akrolein kialakulásáért, mint a Lewis-savas helyek [70, 141].

Emellett aktivitást meghatározó szerepe van egyéb paramétereknek, például a víznek, a katalizátor hidrofobicitásának [70], a külső felület nagyságának, a pórusméretnek, a reakcióidőnek és -hőmérsékletnek [78], stb.

A glicerin-víz arány a glicerin konverziójára nem volt jelentős befolyással, amíg azt 2-11 között tartották, viszont a víz arányának ezen túli emelése növelte az akrolein szelektivitását $[70,78]$.

Jia és Liu vizsgálataiban a nanokristályos szerkezetü HZSM-5 jobb katalitikus aktivitást és stabilitást mutatott, mint a „tömb” szerkezetü HZSM-5 [141].

A pórusméret növelése ugyan elősegíti a glicerin savas helyekhez való hozzáférhetőségét, ezáltal az aktivitás növekedését, de az akroleinszelektivitás jelentősen csökken. Ez a viselkedés jó egyezést mutat a hordozóra vitt foszfátok estén tapasztaltakkal, miszerint a mikropórusos (5--6 Å) katalizátorok bár kevésbé aktívak, de szelektívebbek, mint a mezopórusos, aktív, de akroleinre kevéssé szelektív minták [64].

Yoda és Ootawa glicerin HZSM-5-katalizátoron megvalósuló dehidratációjának mechanizmusát tanulmányozva megállapították, hogy a viszonylag szűk csatornákban a glicerin $\mathrm{C} 2$ pozícióban lévő OH-csoportja szelektíven tud kölcsönhatásba lépni a Brønsted-savcentrumokkal (amit a Si-(OH)-Al egységek OH-hídjai jelentenek), s ezáltal magas akroleinszelektivitás érhető el [142]. Bár többnyire az akrolein a fötermék, 15,7 \%-os víztartalom mellett az acetol (9 \%) képződése megelőzte az akroleinét (7,2\%) [70]. A dehidratációt általában különböző mellékreakciók kísérik, amelyekben aromás termékek, dehidratált komponensek hidrogénezett származékai, glicerin polikondenzációs termékei és ciklikus glicerin-éterek keletkezhetnek [143]. 


\subsubsection{Hagyományos és új típusú Raney-nikkel-katalizátorok}

\subsubsection{A hagyományos Raney-nikkel, tulajdonságai, elöállítása és alkalmazása}

A hagyományos Raney-nikkel az úgynevezett vázkatalizátorok csoportjába tartozik, melyeknek alkalmazásával már jóval enyhébb reakciókörülmények (alacsonyabb hőmérséklet, esetleg nyomás) mellett is megfelelő, a nemesfémek hatékonyságával összemérhető aktivitás érhető el, és így elkerülhetők az esetleges nem kívánt mellékreakciók [144].

A Raney típusú katalzátorokat széles körben használják különféle telítetlen komponensek hidrogénezésére mind laboratóriumi méretekben, mind a finomkémiai iparban [145-147]. Alkalmazzák többek között olefinek [148], nitrilek [149], oxo- [150] és nitrovegyületek [151], valamint $\mathrm{C}-\mathrm{S}$ és $\mathrm{C}-\mathrm{H}$ kötések [152] telítésére. Erről jó összefoglalást nyújt B.Chen és munkatárainak munkája [153].

Az eredeti recept [154] alapján készített Raney-Ni a katalizátor pórusaiban abszorbeált hidrogén következtében erősen piroforos (öngyulladó). Ez a sajátosság egyrészt előnyös, hiszen a katalizátor ennek köszönheti nagy aktivitását, másrészt hátrányos, ha a reakciórendszer öngyulladásának kockázatát tekintjük. Hogy ezt elkerüljék, a katalizátort víz alatt tartják, és nedves állapotában alkalmazzák a szerves reaktánsok katalízisében. A katalizátor mégis széles körben használatos, hiszen ez a hátrány mellett sok előnyös tulajdonsággal rendelkezik. Viszonylag nagy a sürüsége, ami megkönnyíti az elválasztását, nagy a hővezető-képessége, magas a termikus és szerkezeti stabilitása, és a legtöbb szerves oldószerben csak kevéssé oldódik. Ugyanakkor a szerves savak roncsolják a vázrendszerét, és a nagy alumíniumtartalom is csökkenti a stabilitását.

A vázkatalizátorok előállítása úgy történik, hogy egy katalitikusan aktív fémet inaktív fémmel ötvöznek, majd ezt az inaktív komponenst, leginkább bázisokkal, részben vagy teljesen kioldják. Az így előállított anyagok krisztallitmérete 40-80 Å, míg a hasonló, finom eloszlású és kristályos szerkezetü, de sókból, termikus úton előállított katalizátoroké egy nagyságrenddel nagyobb [144].

A Raney-Ni-katalizátor kiindulási anyaga alumínium és nikkel - általában 1:1 arányú ötvözete, amelyből kb. 20-25 \%-os NaOH-dal kioldják az alumíniumot. Az exoterm reakciót heves habzás kíséri. A müvelet szigorú szabályozás mellett történik, és akár órákig is eltarthat. Ezután a kapott anyagot semlegesre mossák. A visszamaradó fém 90-95 \% nikkelt tartalmazó, szivacsos szerkezetü, finom eloszlású por, mely viszonylag nagy felülettel rendelkezik, és az aránylag nagy mennyiségü adszorbeált/abszorbeált hidrogén miatt piroforos tulajdonságú $[155,156]$. 


\subsubsection{Az új típusú Raney-nikkel, tulajdonságai és elöállítása}

Az említett öngyulladó hajlam elkerülése, de a nagy katalitikus aktivitás megtartása érdekében intenzív kutatások folynak.

Termikus deszorpcióval [157] vagy kémiai/elektrokémiai oxidációval [158, 159] vagy a két módszer ötvözésével [160] sikerült az adszorbeált hidrogén nagyobb részét eltávolítani, amivel ugyan a piroforosság megszünt, viszont a deszorpció után kapott jól diszpergált Nikatalizátor aktivitása jóval a kiindulási mintáé alatt maradt $[158,161]$.

Ezzel szemben Petró Józsefnek 50-50 tömeg\% Al-Ni ötvözetporból kiindulva egy új eljárással aktív alumínium-hordozós, nem piroforos és kevéssé ferromágneses Raney-Ni-katalizátort sikerült létrehozni, melynek 25-30 tömeg\%-a jól diszpergált Ni. Ez az új típusú katalizátor ugyanolyan aktív vagy még aktívab, mint a hagyományos Raney-Ni [155].

Az új eljárás abban különbözik az előzőektől, hogy enyhébb körülmények (kisebb koncentrációjú lúg) hatására az inaktív ötvöző fém csak részben oldódik, így a Ni-részecskék távolabb kerülnek egymástól, ezáltal a piroforosság megszünik, ami nagymértékben megkönnyíti felhasználhatóságát, hiszen a katalizátort nem kell speciálisan inert körülmények között tartani [155].

Az újfajta elöállítás nemcsak egyszerübb, olcsóbb és gyorsabb, de kevesebb környezeti problémát is okoz a hagyományos eljárásnál. Azonos mennyiségü, ugyanolyan ötvözetporból $2000 \mathrm{~cm}^{3}(2,2 \mathrm{~kg})$ nedves katalizátor állítható elő 70 perc alatt, $7 \mathrm{dm}^{3}$ víz és $0,195 \mathrm{~kg} \mathrm{NaOH}$ felhasználásával, míg korábban a $0,5 \mathrm{~kg}\left(350 \mathrm{~cm}^{3}\right)$ katalizátor létrehozásához 270 percre, 8 $\mathrm{dm}^{3}$ vízre és 2,1 kg NaOH-ra volt szükség. Mivel nem tiszta, hanem Al-hidrát, -oxihidrát hordozós AlNi-röl van szó, sürüsége kisebb, így könnyebb keverni, egyenletesen eloszlatni és szürni. A fém részecskemérete kisebb, mint a hagyományos eljárással nyert mintáé, enyhén mágneses és nem piroforos [155]. A kiindulási ötvözetben lévő $\mathrm{NiAl}_{3}$ és $\mathrm{Ni}_{2} \mathrm{Al}_{3}$ a $\mathrm{NaOH}-\mathrm{os}$ oldás hatására többnyire átalakult NiAl formává, míg az Al nagy része Al-oxihidrátokká (gibbsit, böhmit, nordstrandit, bayerit), amelyek a köbös szerkezetü intermetallikus nikkelalumínium „hordozóinak” tekinthetők. A minta promotormentes és sem fém $\mathrm{Ni}$, sem $\mathrm{NiO}$ nincs benne [162]. Évekig eltartható anélkül, hogy veszítene aktivitásából [155].

Azt már az 1930-as években felismerték, hogy egy bimetallikus ötvözetben, ha a nemesebb komponens aránya elér egy adott szintet, akkor az ötvözet tulajdonságai nagyon hasonlítanak a tiszta nemesebb féméhez. Ez az érték sok esetben a nemesebb fém 1/8 atomarányának egész számú többszöröse [163]. Jelen esetben a $\mathrm{NiAl}_{3}$ esetén ez 2/8, $\mathrm{Ni}_{2} \mathrm{Al}_{3}$-nál 3/8, míg a NiAl-nál 4/8. A NiAl 4/8 atomaránya a katalitikus karaktert tekintve tehát eléri a kritikus értéket [162]. 
A Petró József nevéhez füződő új típusú Raney-nikkel mintákat a feltalálótól kapta tanszékünk, hogy a dehidrogénezésben és hidrogénezésben már bizonyítottan [145, 146] jól müködő katalizátorokat egyéb reakciókban is teszteljük.

\subsubsection{Hidrotalcit- és keverékoxid-katalizátorok}

\subsubsection{Réteges szerkezetek csoportosítása, a hidrotalcitok története}

A természetes hidrotalcitot (magnézium-alumínium hidroxikarbonát) 1842 körül fedezték fel Svédországban [164], de összetételét csak 1915-ben írták le [165, 166]:

$$
\mathrm{Mg}_{6} \mathrm{Al}_{2}(\mathrm{OH})_{16}\left(\mathrm{CO}_{3}\right) \cdot 4 \mathrm{H}_{2} \mathrm{O}
$$

A hidrotalcit nevét a magas víztartalma és a talkhoz való hasonlósága miatt kapta. Bár a természetben nem túl gyakori, iparilag könnyen és viszonylag olcsón elő lehet állítani.

Gyártása az 1940-es évek elején kezdődött. Ekkor a szerkezetét úgy képzelték, hogy az egyik kation hidroxidos rétege beékelődik a másik kation hidroxidrétegébe [167]. Ezt a feltevést csak majdnem harminc évvel később cáfolták meg, röntgenfelvételek eredményeire támaszkodva [168, 169].

A réteges szerkezeteket a következőképp csoportosíthatjuk [170, 171]:

1) semleges rétegek, pl. brucit $\left(\mathrm{Mg}(\mathrm{OH})_{2}\right)$;

2) negatív töltésủ rétegek kompenzáló kationokkal a rétegek közti térben, pl. a természetben gyakori kationos agyagásványok, mint a montmorillonit;

3) pozitív töltésü rétegek, melyek töltését anionok kompenzálják a rétegek közt.

Ebbe a harmadik, anioncserélő agyagásványok csoportjába tartoznak a réteges kettős hidroxidok (layered double hydroxide, $L D H$ ), melyeket a természetben előforduló képviselöjük után hidrotalcitszerü anyagoknak, vagy egyszerüen hidrotalcitoknak (HT) is neveznek.

\subsubsection{A hidrotalcitok szerkezete és tulajdonságai}

A hidrotalcitok sík lapokból épülnek fel, amelyek brucit $\left(\mathrm{MgOH}_{2}\right)$ szerkezettel rendelkeznek. Míg a brucitlapokban hat hidroxilcsoport vesz körbe egy kétértékü kationt $\left(\mathrm{Mg}^{2+}\right)$ egy oktaéderes cellát képezve, addig a hidrotalcitban a $\mathrm{Mg}^{2+}$-ionok egy részét háromértékü kation $\left(\mathrm{Al}^{3+}\right)$ helyettesíti, pozitív töltést kölcsönözve a rétegnek. A rétegek között töltéskompenzáló anionok és vízmolekulák helyezkednek el [165, 172, 173].

A hidrotalcitok általános képlete a következőképp adható meg:

$$
\left[\left(\mathrm{M}^{2+}\right)_{\mathrm{n}}\left(\mathrm{M}^{3+}\right)_{\mathrm{m}}(\mathrm{OH})_{2(\mathrm{~m}+\mathrm{n})}\right]^{\mathrm{m}+}\left[\left(\mathrm{A}_{\mathrm{m} / \mathrm{x}}\right)^{\mathrm{x}-}\right] \cdot \mathrm{y} \mathrm{H}_{2} \mathrm{O}
$$


ahol $M^{2+}$ kétértékü kationokat ( pl. $\left.\mathrm{Mg}^{2+}, \mathrm{Cu}^{2+}, \mathrm{Zn}^{2+}, \mathrm{Mn}^{2+}, \mathrm{Ni}^{2+}, \mathrm{Co}^{2+}, \mathrm{Fe}^{2+}, \mathrm{Cu}^{2+}\right)$;

$M^{3+}$ háromértékü kationokat ( $\left.\mathrm{pl} . \mathrm{Al}^{3+} \mathrm{Cr}^{3+}, \mathrm{Fe}^{3+}, \mathrm{Mn}^{3+}, \mathrm{Ga}^{3+}\right)$;

$A^{x-} x$-értékű kompenzáló anionokat (pl. $\mathrm{NO}_{3}^{-}, \mathrm{Cl}^{-}, \mathrm{CO}_{3}{ }^{2-}$, heteropolisavak, szerves savak);

$y$ a rétegek közti $\mathrm{H}_{2} \mathrm{O}$ molekulák számát jelenti [171, 174].

Az $m$ általánosságban elfogadott értéke 0,2-0,33 között van. Ha $m>0,33$, akkor a szomszédos $\mathrm{Al}^{3+}$ ionok egy $\mathrm{Al}(\mathrm{OH})_{3}$ fázist (gibbsit) hoznak létre, míg ha $m$ értéke kicsi, nagy sűrüségü oktaéderes magnéziumzónák keletkeznek, melyek a hidromagnezit $\left[\mathrm{Mg}(\mathrm{OH})_{2}\right]$ gócképződési centrumai [172].

A megadott összegképletü anyagnak két formája létezik: a romboéderes hidrotalcit és a hexagonális manasseit. Előbbiben elemi cellánként három dupla réteg van jelen, míg utóbbiban kettö [175].

A bázislapok távolságát az anionok mérete befolyásolja. A 20. ábra olyan MgAl-hidrotalcit szerkezetét mutatja, ahol a kompenzáló anion a karbonát [176].

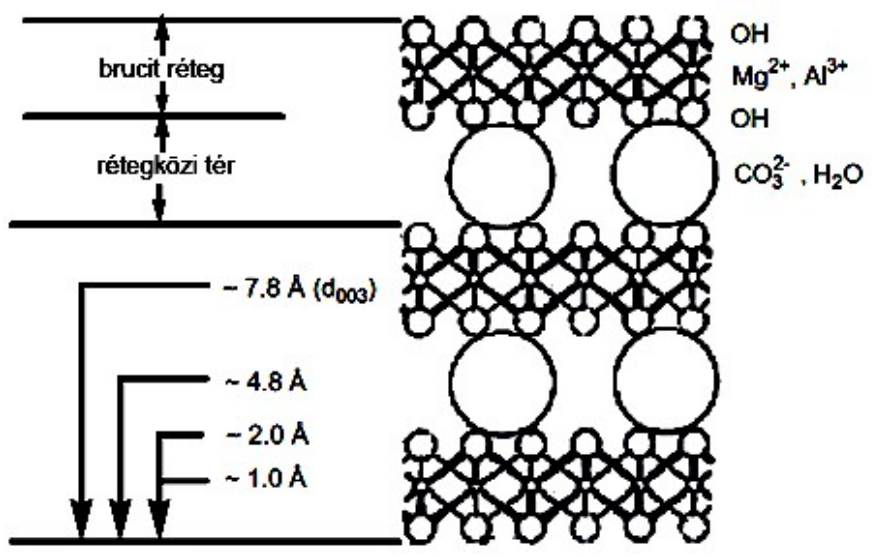

20. ábra: $\mathrm{MgAl}-\mathrm{LDH}-\mathrm{CO}_{3}$ sematikus képe [176]

Különböző kationok beépítésével, akár egy- és háromértékű, vagy két- és négyértékű kationok kombinálásával változatos összetétel érhető el, de fontos kritérium, hogy a szerkezetbe vitt kation sugara ne térjen el jelentős mértékben a $\mathrm{Mg}^{2+}$-ionétól. A két- és háromértékü ionok aránya szintén változó lehet, a tiszta MgAl-HT esetén ez általában 2 és 4 közé esik [164].

Mivel a háromértékű kationok beépítése pozitív töltést kölcsönöz a rétegeknek, ezért különösen hatékonyak az anionok felvételében, kicserélésében. Miyata [177] tanulmányai alapján a hidrotalcitok anionokhoz való affinitása a következő sorrend szerint alakul:

$$
\mathrm{CO}_{3}{ }^{2-}>>\mathrm{SO}_{4}{ }^{2-}>>\mathrm{OH}^{-}>\mathrm{F}^{-}>\mathrm{Cl}^{-}>\mathrm{Br}^{-}>\mathrm{NO}_{3}{ }^{-}
$$

Ebből következően, ha ioncserét szeretnénk végrehajtani, akkor nem célszerü karbonátot 
használni az elóállításhoz.

A változatos összetételen túl, a hidrotalcitok lényeges tulajdonsága, a réteges szerkezet, és az, hogy a rétegek közötti tér növelhető azok kitámasztásával.

Fontos sajátosságuk az úgynevezett „emlékezö hatás” (memory effect) is, melyet elöször Miyata írt le [178]. Ez azt jelenti, hogy enyhe körülmények közt kalcinálva, a dehidratáció során kialakuló $\mathrm{Mg}(\mathrm{Al}) \mathrm{O}$ keverékoxid vízzel érintkezve (folyadék- vagy gázfázisban) képes helyreállítani az eredeti lamellás szerkezetet (21. ábra).

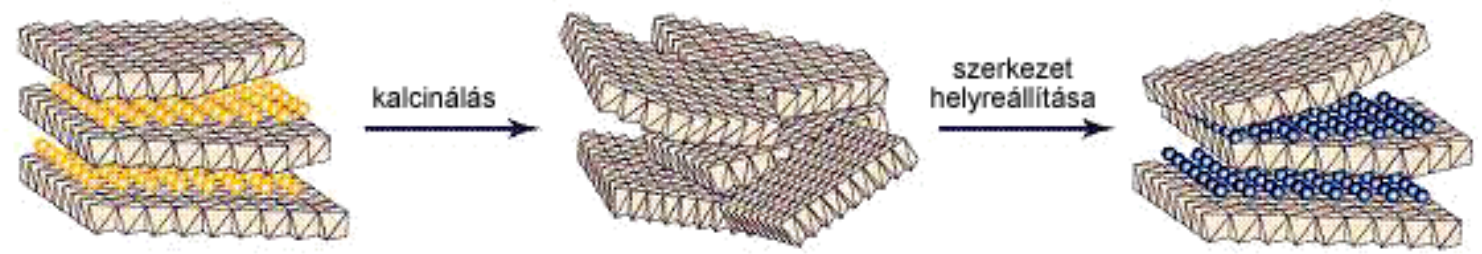

21. ábra: Hidrotalcitok emlékező szerkezete [171

A kalcináláskor keletkező keverékoxid tartalmaz erös $\mathrm{O}^{2-}$ Lewis bázis helyeket, $\mathrm{M}^{\mathrm{n}+}-\mathrm{O}^{2-}$ Lewis-sav-bázis párokat, $\mathrm{OH}^{-}$Brønsted-bázis és $\mathrm{M}^{\mathrm{n}+}$-savas helyeket [179, 180], míg a rehidrálás során a Lewis-centrumok (a váz oxigénjei) Brønsted-báziscentrumokká $\left(\mathrm{OH}^{-}\right)$alakulnak [181]. Az így létrejövő $\mathrm{Mg} / \mathrm{Al} / \mathrm{OH}$ típusú réteges kettőshidroxidokat meixneritnek nevezik [171]. A kalcinált forma többnyire bázikus karakterü, különösen ha $\mathrm{MgO}$ is van az alkotóelemek között [182].

A visszaalakulásra azért van mód, mert a kationok többé-kevésbé a keverékoxidon belül is megörzik pozíciójukat. Ez úgy lehetséges, hogy a kalcinálás során „kráterek” (20--40 A méretủ mezopórusok) képződnek, s például a karbonátionokból származó $\mathrm{CO}_{2}$ [vagy a nitrátból származó $\mathrm{NO}$ (és $\mathrm{NO}_{2}$ )] ezeken keresztül távozik el. Így a rétegek nem omlanak össze az interlamelláris erők miatt. Az átalakulás jelentős felületnövekedéssel jár.

A rehidratálással kapott, részlegesen cserélt vegyület a következö képlettel írható le:

$$
\left[\mathrm{Mg}_{\mathrm{n}} \mathrm{Al}_{\mathrm{m}}(\mathrm{OH})_{2(\mathrm{~m}+\mathrm{n})}\right]^{\mathrm{m}+}\left[(\mathrm{OH})_{\mathrm{m}}\left(\mathrm{H}_{2} \mathrm{O}\right)_{\mathrm{x}}\right]^{\mathrm{m}-},
$$

ahol $0,20<m<0,33$ [181].

A dehidratálás-rehidratálás módszerét széles körben használják a hidrotalcitok aktiválására is. Ennek lényege, hogy Brønsted-bázis helyeket $\left(\mathrm{OH}^{-}\right)$viszünk a lamellák közti térbe. A folyamat egyéb morfológiai változásokkal is jár [183]. A kalcinálás hőmérséklete tipikusan $450{ }^{\circ} \mathrm{C}$ [166, 184-187], ami elég magas hőmérséklet ahhoz, hogy a keverékoxid már biztosan kialakuljon, de elég alacsony ahhoz, hogy a réteges szerkezetet vissza lehessen nyerni. 
A visszaalakulás feltétele, hogy a kalcinálás hömérséklete ne lépje túl azt a határt $\left(450-600{ }^{\circ} \mathrm{C}\right)[185,188]$, ahol az ún. spinellfázis $\left(\mathrm{MgAl}_{2} \mathrm{O}_{4}\right)$ megjelenik $[164,171]$. Ha a hömérsékletet tovább emeljük, akkor a hidrotalcit réteges szerkezete a $\mathrm{CO}_{2}$ és a hidroxidokból eredő víz elvesztésével fokozatosan összeomlik a következő egyenletek [189] szerint:

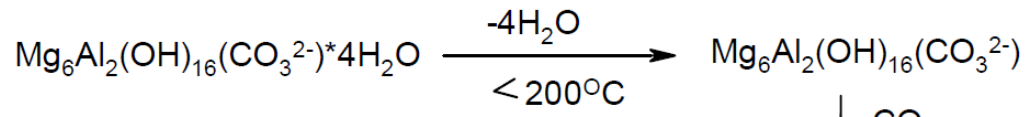

$$
\begin{aligned}
& >200^{\circ} \mathrm{C} \mid \begin{array}{l}
-\mathrm{CO}_{2} \\
-7 \mathrm{H}_{2} \mathrm{O}
\end{array} \\
& \mathrm{Mg}_{6} \mathrm{Al}_{2} \mathrm{O}_{8}\left(\mathrm{OH}^{-}\right)_{2}
\end{aligned}
$$

A $900{ }^{\circ} \mathrm{C}$ [181] - $1000{ }^{\circ} \mathrm{C}$-on [190] megjelenő $\mathrm{MgO}$ és $\mathrm{MgAl}_{2} \mathrm{O}_{4}$ (spinell) szerkezet már biztosan nem alakítható vissza. A keletkező homogén, stabilis, katalitikusan aktív fém-oxidok keveréke nagy fajlagos felülettel, illetve kis kristálymérettel rendelkezik [171, 172].

\subsubsection{A hidrotalcitok felhasználása és elöállítása}

A fentebb említett tulajdonságainak (változatos összetétel, viszonylag nagy fajlagos felület, réteges szerkezet, kitámasztható rétegek, bázikusság és emlékező szerkezet) köszönhetően a hidrotalcitokat, és a belőlük nyert keverékoxidokat egyre szélesebb körben használják. Alkalmazzák őket például a biodízel-gyártásban [191], a PVC-gyártásban hőstabilizátorként [192], és a mủanyaggyártásban égésgátló adalékként [193]. A gyógyászatban savlekötőként [194] és gyógyszerhordozóként [195] használatosak. Továbbá sikerrel alkalmazhatók, mint adszorbensek, például a foszfátok és nehézfémek megkötésére a szennyvíztisztításban [196], talajok és üledékek remediációjában [197]. Ezen túl felhasználják öket anioncserélöként [198] vagy mint katalizátorhordozókat [199, 200], katalizátorokat [171, 201-203]. A leggyakrabban fémek kloridjait vagy nitrátjait használják a szintézisben, mert azokat könnyü szerkezetbe vinni, ugyanakkor könnyen ki is cserélhetők. LDH-k előállítására többnyire a következő négy módszer valamelyikét alkalmazzák: együttes lecsapás [204, 205], ioncsere [206], kalcinálás-rehidratálás [207] vagy hidrotermális eljárás [178, 208, 209]. Ezek közül az egyik legelterjedtebb az együttes lecsapás (koprecipitáció), amikor állandó pH-t tartva a fémsók oldatát összecsepegtetik a bázissal, és így a kívánt fémkationok hidroxidjai egyidejüleg válnak ki a rendszerből. A folyamat előnye, hogy változatos összetételt lehet vele elérni [205].

A hidrotalcit környezetbarát és ára sem túl magas, így ha esetleg a katalizátor nem használható újra, akkor egyszerüen eltávolítható a reakcióelegyből, és friss katalizátor használható helyette. 


\section{Kísérleti rész}

\subsection{Felhasznált anyagok}

\subsubsection{Szintézishez használt anyagok}

\subsubsection{ZSM-5 zeolitok}

Ludox-HS40 (40 m/m\% SiO 2 vizes szuszpenzió, Na stabilizátor) Aldrich

Nátrium-hidroxid $(\mathrm{NaOH})$

Molar Chemicals

Nátrium-klorid $(\mathrm{NaCl})$

Molar Chemicals

Tömény kénsav $\left(\mathrm{H}_{2} \mathrm{SO}_{4}\right)$

Molar Chemicals

Tetrapropilammónium-bromid (TPA-Br, $\mathrm{C}_{12} \mathrm{H}_{28} \mathrm{BrN}$ )

Merck

Titán(IV)-klorid $\left(\mathrm{TiCl}_{4}, 99,9 \%\right)$

Aldrich

Alumínium-klorid $\left(\mathrm{AlCl}_{3} \cdot 6 \mathrm{H}_{2} \mathrm{O}\right)$

Molar Chemicals

Ammónium-klorid $\left(\mathrm{NH}_{4} \mathrm{Cl}\right)$

Molar Chemicals

Réz-klorid $\left(\mathrm{CuCl}_{2} \cdot 2 \mathrm{H}_{2} \mathrm{O}, 99,0 \%\right)$

Aldrich

Nikkel-klorid $\left(\mathrm{NiCl}_{2} \cdot 6 \mathrm{H}_{2} \mathrm{O}, 98,0 \%\right)$

Molar Chemicals

Króm-klorid $\left(\mathrm{CrCl}_{3} \cdot 6 \mathrm{H}_{2} \mathrm{O}, 98,0 \%\right)$

Aldrich

\subsubsection{2. Új típusú Raney-nikkel-katalizátorok}

Készen kaptuk tesztelésre, de a szintéziséhez a következő anyagokat használták:

Ni-Al ötvözet por (45 $\mu \mathrm{m}$ részecskeméret, $50-50 \%$ tömegarány)

Ni-Si ötvözet por (50 $\mu \mathrm{m}$ részecskeméret, $50-50 \%$ tömegarány)

$\mathrm{NaOH}$

\subsubsection{Réteges kettős hidroxidok}

$\begin{array}{ll}\text { Alumínium-nitrát }\left(\mathrm{Al}\left(\mathrm{NO}_{3}\right)_{3} \cdot 9 \mathrm{H}_{2} \mathrm{O}\right) & \text { Reanal } \\ \text { Magnézium-nitrát }\left(\mathrm{Mg}\left(\mathrm{NO}_{3}\right)_{2} \cdot 6 \mathrm{H}_{2} \mathrm{O}\right) & \text { Reanal } \\ \text { Króm-nitrát }\left(\mathrm{Cr}\left(\mathrm{NO}_{3}\right)_{3} \cdot 9 \mathrm{H}_{2} \mathrm{O}\right) & \text { Reanal } \\ \text { Réz-nitrát }\left(\mathrm{Cu}\left(\mathrm{NO}_{3}\right)_{2} \cdot 6 \mathrm{H}_{2} \mathrm{O}\right) & \text { Reanal } \\ \text { Nikkel-nitrát }\left(\mathrm{Ni}\left(\mathrm{NO}_{3}\right)_{2} \cdot 6 \mathrm{H}_{2} \mathrm{O}\right) & \text { Reanal } \\ \text { Nátrium-hidroxid }(\mathrm{NaOH}) & \text { Reanal } \\ \text { Nátrium-karbonát }\left(\mathrm{Na}_{2} \mathrm{CO}_{3}\right) & \text { Reanal }\end{array}$

\subsubsection{Katalitikus tesztreakcióban használt anyagok}

Glicerin $\left(\mathrm{C}_{3} \mathrm{H}_{5}(\mathrm{OH})_{3}, 87 \%\right)$

Molar Chemicals 


\subsubsection{Gázkromatográfiás analízisben használt anyagok}

2-Propanol $\left(\mathrm{C}_{3} \mathrm{H}_{8} \mathrm{O}\right)$ (desztillációs maradék hígítására)

Molar Chemicals

Acetol $\left(\mathrm{C}_{3} \mathrm{H}_{6} \mathrm{O}_{2}, 90 \%\right)$

Sigma-Aldrich

Akrolein $\left(\mathrm{C}_{3} \mathrm{H}_{4} \mathrm{O}, 90 \%\right)$

Sigma-Aldrich

3-Hidroxi-propionaldehid

Allorachem

DL-glicerinaldehid $\left(\mathrm{C}_{3} \mathrm{H}_{6} \mathrm{O}_{3}\right)$

Sigma-Aldrich

Glikol-aldehid $\left(\mathrm{C}_{2} \mathrm{H}_{4} \mathrm{O}_{2}\right)$

Sigma-Aldrich

1,3-Propándiol $\left(\mathrm{C}_{3} \mathrm{H}_{8} \mathrm{O}_{2}, 98 \%\right)$

Sigma-Aldrich

$\mathrm{S}(+)$-1,2-Propándiol $\left(\mathrm{C}_{3} \mathrm{H}_{8} \mathrm{O}_{2}\right)$

Sigma-Aldrich

Allilalkohol $\left(\mathrm{C}_{3} \mathrm{H}_{6} \mathrm{O}, 98,5 \%\right)$

Sigma-Aldrich

Acetaldehid $\left(\mathrm{CH}_{3} \mathrm{CHO}\right)$

Sigma-Aldrich

Formaldehid $\left(\mathrm{CH}_{2} \mathrm{O}\right)$

Sigma-Aldrich

Etilénglikol $\left(\mathrm{C}_{2} \mathrm{H}_{6} \mathrm{O}_{2}\right)$

Sigma-Aldrich

Metanol $\left(\mathrm{CH}_{3} \mathrm{OH}\right)$

Sigma-Aldrich

\subsection{A katalizátorok előállítása}

\subsubsection{ZSM-5 zeolitok}

A $\mathrm{Si} / \mathrm{Al}=13,8$ névleges modulussal rendelkező ZSM-5 alapzeolitok szerkezetébe $-\mathrm{a}$ templát eltávolítása, és esetenként egyéb kezelések után - a rezet szilárd-, a krómot folyadékfázisú ioncserével vittem be. A Ni-tartalmú minta előállítására mindkét módszert alkalmaztam, míg a Ti-ZSM-5 szintézise izomorf szubsztitúcióval történt.

\subsubsection{Az alapzeolit elóállítása}

A ZSM-5 (MFI) szerkezetü katalizátorok a Fejes Pál és munkatársai által ismertetett szolgél eljárást [210] alapul véve készültek.

Ha a Na-szilikát (vízüveg) alacsony hőmérsékleten híg savval reagál (pH 2), kovasav képződik. Viszonylag sok fémion $\left(\mathrm{M}^{\mathrm{n}+}\right)$ képes reakcióba lépni a kovasavval, és fém ortoszilikát szolt (-M-O-Si-O) képezni [210].

A szintézis során egyrészt kénsavval megsavanyított desztillált vízhez $(\mathrm{pH}<1)$ folyamatos keverés mellett kis adagokban hozzáadtam az alumínium-kloridot, másrészt a nátriumszilikát-oldatot vízzel hígítottam, s mindkettőt egy éjszakára hütőszekrénybe helyeztem. Az $\mathrm{AlCl}_{3}$-oldathoz folyamatos keverés mellett cseppenként hozzáadtam a híg szilikátoldatot.

A pH emelésével (pH 4) a szolból szilanolcsoportok kondenzációjával 6-8 óra elteltével 
gél képződik, melyböl összetörés után desztillált vízzel mosva a vízoldható nátriumsók eltávolíthatók. Az így kapott anyag használható a zeolitszintézis prekurzoraként.

Desztillált vízzel hígított tetrapropilammónium-bromid (TPA-Br) oldathoz hozzáadtam a prekurzor gélt és további kovasavat (Ludox), majd 10 órán át tartó intenzív keveréssel homogenizáltam. Ezt követően a kapott anyagot $170{ }^{\circ} \mathrm{C}$-on teflonbélésủ autoklávban hidrotermális körülmények között kristályosítottam 24 órán keresztül. A terméket szürtem, mostam, majd a templát eltávolítása érdekében 2 órán át $600{ }^{\circ} \mathrm{C}$-on levegőáramban kalcináltam [210]. Az így elkészített NaZSM-5 képezte a többi (kivéve a Ti-ZSM-5-öt) zeolitkatalizátor alapját.

\subsubsection{Ti-ZSM-5 elóállítása izomorf szubsztitúcióval}

A Ti-ZSM-5 elöállítása az alapzeolitéhoz hasonló eljárás [210] szerint történt azzal a különbséggel, hogy kiindulási oldat készítésekor az $\mathrm{AlCl}_{3}$ helyett Ti(IV)-kloridot használtam.

A titánsó erősen savas $(\mathrm{pH}<1,0)$ vizes oldatához hozzácsepegtetve a nátrium-metaszilikátoldatot $(\mathrm{Si} / \mathrm{Na}<1,8)$ Ti-ortoszilikát szol keletkezett. A gél képződése $40{ }^{\circ} \mathrm{C}$-on és $\mathrm{pH} 4-4,3$ kémhatás mellett történt. A szintézis után a gélt desztillált vízzel mostam. A tisztítás a TiZSM-5 prekurzor gélnél különösen fontos, hiszen a Ti bevitelét megakadályozhatják az akár csak nyomokban is jelenlévő (alkáli) kationok [211,212]. A gél megfelelő szemcseméretének kialakítása őrléssel történt, amit $170{ }^{\circ} \mathrm{C}$-on való hidrotermális kristályosítás, majd szürés, mosás, szárítás és $600{ }^{\circ} \mathrm{C}$-on megvalósított kalcinálás követett.

\subsubsection{HZSM-5 elöállítása}

A kalcinált NaZSM-5 zeolitot $1 \mathrm{~mol} / \mathrm{dm}^{3}$ koncentrációjú $\mathrm{NH}_{4} \mathrm{Cl}$-oldatban felszuszpendáltam és 24 órán át kevertettem, majd ezt a folyamatot szürés után megismételtem, hogy minél teljesebb mértékben megtörténjen az ammóniumion cseréje. Ezzel előállítottam a $\mathrm{NH}_{4} \mathrm{ZSM}-5$ formát. Mosás után ezt $600{ }^{\circ} \mathrm{C}$-on 4 órán át hőkezeltem, így kaptam az $\mathrm{NH}_{3}$ eltávozásával a HZSM-5 mintát, amely egyrészt jól alkalmazható katalizátorként, másrészt alkalmas alapot biztosít más fémek szilárdfázisú ioncserével történő bevitelére.

\subsubsection{Cr-és NiZSM-5-f elöállítása folyadékfázisú ioncserével}

A fent leírtak szerint kiégetett NaZSM-5-öt az előzetesen elkészített $0,1 \mathrm{~mol} / \mathrm{dm}^{3}$ koncentrációjú króm-, illetve nikkel-klorid oldat fele térfogatával 24 órán át intenzíven érintkeztettem szobahőmérsékleten. Dekantálás után az oldat második felével megismételtem az ioncserét. Ezután a szuszpenziót szürtem, kloridmentesre mostam, szárítottam és 4 órán át $600{ }^{\circ} \mathrm{C}$-on hevítettem. 


\subsubsection{Cu-és NiZSM-5-sz elöállítása szilárdfázisú ioncserével}

A Cu- és NiZSM-5-sz minták előállítása Karge és Beyer szerint [213] történt.

Egy achát mozsárban - a lehetö legnagyobb homogenitásra törekedve - összedörzsöltem 5 tömeg\% fémtartalomra számított fém-kloridot $\left(\mathrm{CuCl}_{2} \cdot 2 \mathrm{H}_{2} \mathrm{O}\right.$, illetve $\left.\mathrm{NiCl}_{2} \cdot 6 \mathrm{H}_{2} \mathrm{O}\right)$ a $\mathrm{HZSM}-5$ zeolittal. A keveréket 4 órán át $600{ }^{\circ} \mathrm{C}$-on izzítottam, majd környezeti hőmérsékletre hülve kloridmentesre mostam és szárítottam.

\subsubsection{Az új típusú Raney-nikkel-katalizátorok előállítása}

Ahogy már korábban említettem, ezeket a katalizátorokat készen kaptuk tesztelésre. Szintézisükkel kapcsolatban a feltalálóktól kapott információk és a már megjelent cikkek álltak rendelkezésemre.

A katalizátorok előállításához $1 \mathrm{~kg} 45 \mu \mathrm{m}$ szemcseméretü 1:1 tömegarányú Ni-Al ötvözetport reakcióedénybe tettek, majd $6 \mathrm{dm}^{3} 1,25 \%$-os NaOH-t adtak hozzá és $100{ }^{\circ} \mathrm{C}$-ra melegítették (5-6 perc), ahol enyhe habzást tapasztaltak. A habzás megszünte után (kb. 30 perc) újabb adag $\left(1 \mathrm{dm}^{3}\right) 70{ }^{\circ} \mathrm{C}$-os, $12 \%$-os NaOH-ot adtak hozzá, és $50{ }^{\circ} \mathrm{C}$-ra hütötték (kb. 20 perc), majd semlegesre mosták és víz alatt tartották. Az így elkészített katalizátor térfogata 12 óra elteltével $2000 \mathrm{~cm}^{3}$, nedves tömege 2200 g, szárítás utáni Ni-tartalma 25-30 mol \% [155].

Az általam használt 222A, 222B és 222C kódszámú, Al-oxihidrátba ágyazott alumínium-nikkel-katalizátorok előállítása a fentebb leírt eljáráshoz hasonlóan történt. Az összes minta $50{ }^{\circ} \mathrm{C}$-on lett szárítva, majd a 222B- és $222 \mathrm{C}$-katalizátorok további 120 illetve $320{ }^{\circ} \mathrm{C}$ on történő 60 perces hőkezelésen estek át. A kapott katalizátorok Ni-tartalma a hőkezelés mértékétől függően 45-59 tömeg\% volt.

Alkalmaztunk még egy 212 jelzésű katalizátort, melyben az Al-ot Si helyettesíti. A kiindulási Ni:Si arány 50-50\% volt, de a kész katalizátor Ni-tartalma 40, Si-tartalma 45 tömeg\%, s így az szilíciumba ágyazott Ni-szilicidnek tekinthető. Bár a hőkezelés nem befolyásolta a szerkezetet, a minta készítésekor az $50{ }^{\circ} \mathrm{C}$-os szárítást, a könnyebb összehasonlítatóság érdekében, $320^{\circ} \mathrm{C}$-os kalcinálás követte.

Ahogy az ötvözetporból kioldják az Al egy részét, az enyhén lúgos oldatból polimorf trihidrátok $\left[\mathrm{Al}(\mathrm{OH})_{3}\right]$ válnak ki. A bayerit és a gibbsit monoklin, míg a nordstrandit triklin rendszerben kristályosodik. A hőmérséklet emelésével a víz jelentős hányada eltávozik, és a trihidrátok egy része ortorombos szerkezetü monohidráttá, böhmitté $[\mathrm{AlO}(\mathrm{OH})]$ alakul.

A különböző hőmérsékleten megvalósuló átalakulásokról részletesebben a termogravimetriáról szóló 4.3.2. fejezetben lehet olvasni. A röntgenfelvételek alapján azt tapasztaltam, hogy 
a böhmit már a 222A és 222B nevü mintákban is szerepel, de a magasabb hőmérsékletủ kezelés hatására aránya nő, s ezzel párhuzamosan csökken a trihidrátok mennyisége, illetve egyre hangsúlyosabbá válik az intermetallikus alumínium-nikkel ( $\left.\mathrm{AlNi}, \mathrm{Al}_{3} \mathrm{Ni}_{2}\right)$ jelenléte.

\subsubsection{Hidrotalcit- és keverékoxid-katalizátorok előállítása}

A réteges kettős hidroxidokat együttes lecsapással állítottam elő Dimotakis és Pinnavaia munkáját [214] alapul véve a következőképpen: $500 \mathrm{~cm}^{3}$ vízben feloldottam $0,200 \mathrm{~mol}$ (53,2 g) $\mathrm{Mg}\left(\mathrm{NO}_{3}\right)_{2} \cdot 6 \mathrm{H}_{2} \mathrm{O}$-t és $0,100 \mathrm{~mol}(38,9 \mathrm{~g}) \mathrm{Al}\left(\mathrm{NO}_{3}\right)_{3} \cdot 9 \mathrm{H}_{2} \mathrm{O}$-t. Így kaptam az $A$-oldatot. A $B$ oldat $0,050 \mathrm{~mol}(5,50 \mathrm{~g}) \mathrm{Na}_{2} \mathrm{CO}_{3}$ és $0,620 \mathrm{~mol}(24,9 \mathrm{~g}) \mathrm{NaOH}-t$ tartalmazott $250 \mathrm{~cm}^{3}$ vízben oldva. A $\mathrm{Na}_{2} \mathrm{CO}_{3} / \mathrm{NaOH}$ és $\mathrm{Mg}\left(\mathrm{NO}_{3}\right)_{2} / \mathrm{Al}\left(\mathrm{NO}_{3}\right)_{3}$ oldatokat folyamatos keverés és jeges hütés mellett, erősen lúgos pH-t biztosítva, kb. 2-3 óra alatt egy főzőpohárba csepegtettem, ami így gélt képzett. Ezt a gélt 18 órán át tartottam folyamatos keverés mellett $65^{\circ} \mathrm{C}$-os olajfürdőben, ezután mostam, szürtem és szárítottam. Az így kapott anyagot tekintem „módosítatlan” vagy MgAl-LDH-nak, melyet ezután 24 órán keresztül $400{ }^{\circ} \mathrm{C}, 500{ }^{\circ} \mathrm{C}$ illetve $600{ }^{\circ} \mathrm{C}$-on izzítottam, hogy megfelelő szerkezetet alakítsak ki. A Cr-tartalmú minták az $\mathrm{Al}\left(\mathrm{NO}_{3}\right)_{3} \quad 10 \%$-ának $\mathrm{Cr}\left(\mathrm{NO}_{3}\right)_{3}$-tal való kicserélése során keletkeztek, míg a Cu-t és a Ni-t a Mg $10 \%$-ának helyettesítésével vittem a szerkezetbe. A továbbiakban ezeket a mintákat a módosító fém (Me) alapján Me-HT vagy -LDH, illetve MeMgAl-HT és -LDH névvel jelölöm.

\subsection{Vizsgálati módszerek és müszerek}

\subsubsection{Röntgendiffraktometria}

A katalizátorok kristályszerkezetét Rigaku Miniflex II típusú röntgendiffraktométerrel vizsgáltam a reakció előtt és után, illetve a regenerálást követően. A $2 \theta=3-80^{\circ}$ szögtartományban $0,02^{\circ}$ lépésenként végeztem a mérést, melyhez nikkel monokromátorral fókuszált $\mathrm{CuK}_{\alpha}$ sugárzást (hullámhossza $\lambda=1,54056 \AA$ ) és detektorként szcintillációs számlálót alkalmaztam.

A kristályfázisok azonosítása PCPDFWIN program (2.3 verzió, JCPDS-ICDD 2002) segítségével történt, ami az JCPDS-ICDD (Joint Committee on Powder Diffraction International Centre for Diffraction Data) adatbázisát használja. Így információt kaptam a Miller-indexekről (hkl) is. A megfelelő csúcsok kiválasztása után az Origin (8.1 verzió) program segítségével meghatároztam a szükséges paramétereket, úgymint az adott csúcs pontos helyét és félértékszélességét. Ehhez a megfelelő $2 \theta$ szögekhez tartozó intenzitásadatokból megrajzoltam a csúcsot, majd alapvonalat és Lorentz-görbét illesztettem, és leolvastam a kapott adatokat.

A vizsgált reflexióhoz tartozó $\theta$ szög ( $2 \theta$ szöget mérjük) és a röntgensugárzás $\lambda$ hullámhosszának ismeretében a Bragg-egyenlet (11. egyenlet) segítségével meghatároztam a rács- 
síkok közötti távolságokat (d) (22. ábra).

$$
n \lambda=2 d \sin \theta
$$

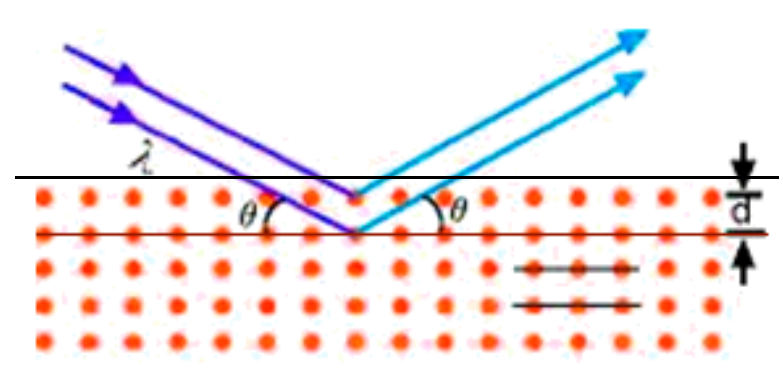

22. ábra: Beeső és visszaverődő sugárnyaláb

A Scherrer-egyenlettel (12. egyenlet) pedig kiszámíthatók az $a, b, c$ rácsparaméterek, az adott irányba mutató kristályméret. Ha egy anyag kiterjedése több irányban is hasonló, vehetjük ezeknek a számtani közepét is, az átlagos részecskeátmérőt $(D)$.

$$
D=\frac{k \times \lambda}{\beta \times \cos \theta}
$$

ahol $D$ az átlagos részecskeátmérő,

$k$ a részecskealakra jellemző (Scherrer) állandó $(0,9)$,

$\lambda$ az alkalmazott sugár hullámhossza (1,54056 $)$,

$\beta$ a csúcs félértékszélessége radiánban $\left(1^{\circ}=0,0175 \mathrm{rad}\right)$,

$\theta$ a vizsgált csúcs középértékéhez tartozó szög (a $2 \theta$ szög fele).

\subsubsection{Nitrogén fiziszorpciós vizsgálatok}

A fiziszorpciós vizsgálatokkal meghatározhatjuk az olyan textúrát és morfológiát jellemző paramétereket, mint a katalizátor fajlagos felülete, a pórusok mérete, alakja, térfogata és a pórusméret-eloszlás. Az önként végbemenő adszorpciós folyamat során a gázmolekulák van der Waals kölcsönhatással megkötődnek a szilárd (elözőleg gáztalanított) felületen, és a nyomás csökkentésekor deszorbeálódnak. Ha a felvett/leadott gáz térfogatát ábrázoljuk a relatív nyomás függvényében, megkapjuk az adszorpciós és deszorpciós izotermákat, melyek alakja függ a szilárd mintától és a gáztól, és a legtöbbjük besorolható a IUPAC szerinti 6 csoport (23. ábra) egyikébe [215].

Az elöállított katalizátorok adszorpciós izotermáit és fajlagos felületét Quantachrome NOVA 2200 típusú gázszorpciós készülékkel határoztam meg. A méréshez minimum $4 \mathrm{~m}^{2}$ nek megfelelő mennyiségü anyagot helyeztem a mintatartó cellába, és vákuumban 180 illetve 
$300{ }^{\circ} \mathrm{C}$-on történő gáztalanítás után a folyékony nitrogén forráspontjának $\left(-196{ }^{\circ} \mathrm{C}\right)$ hömérsékletén felvettem a nitrogén-adszorpciós és -deszorpciós izotermákat. Az adatok kiértékelését a NovaWin nevü programmal (1.11 verzió) végeztem. A fajlagos felületet az adszorpciós izoterma 0,1-0,3 relatív nyomáshoz tartozó értékeiből a BET módszerrel [216] határoztam meg. A pórusok alakjára az izoterma (és esetlegesen a hiszterézis-hurok) alakja utal.

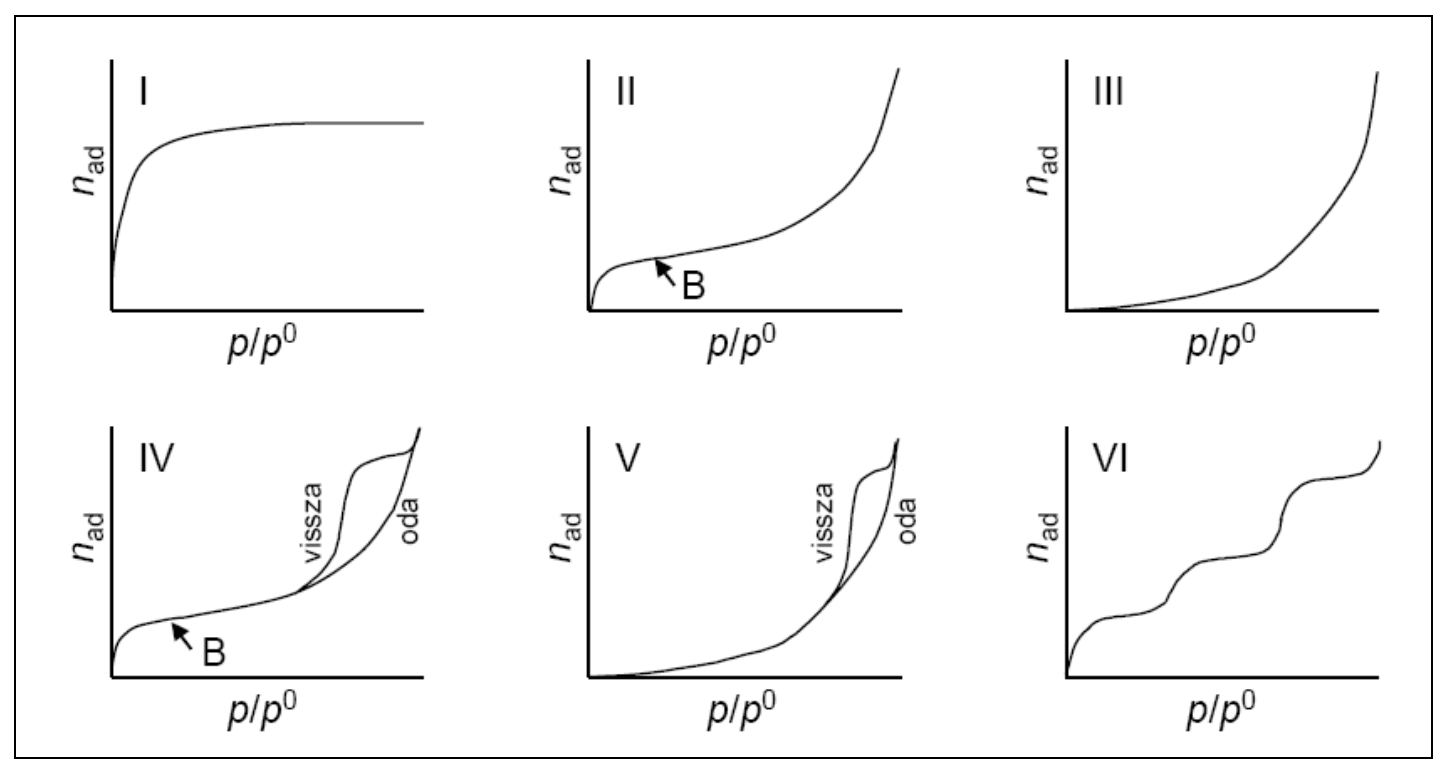

23. ábra Fiziszorpciós izotermák IUPAC szerinti osztályozási rendszere

\subsubsection{Termikus analitikai mérések}

A termogravimetriás analízis (TG) meghatározott atmoszférában megmutatja a hőmérséklet emelésével (vagy az idő függvényében) történő tömegvesztést. Ennek deriváltja (DTG) arról nyújt információt, hogy az adott tömegváltozás mikor indul meg, mikor fejeződik be, és mely hőmérséklethez köthető a tömegvesztés maximuma. Megmutatja a vizsgált anyag hőstabilitását, és hogy a tömegvesztés során egy vagy több reakció játszódik-e le [190]. Ha a höáramot (heat flow, $H F$ ) követjük az eltelt idö függvényében, elmondható, hogy ha a HF lefelé változik, akkor endoterm folyamat történik, ha pedig fölfelé, akkor exoterm a reakció.

A TG méréseket Setaram Labsys típusú müszerrel végeztem, oxigén-atmoszférában. A mérés során a kis mennyiségű (kb. $25 \mathrm{mg}$ ) mintát egy speciális mintatartóba helyeztem, mely egy érzékeny mérlegen helyezkedik el. A müszer programozott mértékben $\left(10{ }^{\circ} \mathrm{C} /\right.$ perc $)$ emelte a hőmérsékletet szobahőmérsékletről $600{ }^{\circ} \mathrm{C}$-ra (illetve $700{ }^{\circ} \mathrm{C}$-ra) és rögzítette az ennek során az anyagban fellépő tömegvesztést és a hőáramot. A SetSoft programból nyert adatokat az Origin program segítségével ábrázoltam és értékeltem. 


\subsection{Katalitikus tesztreakciók}

\subsubsection{Kísérleti berendezés és a mérés körülményei}

A fentebb említett módon elkészített katalizátorokat glicerin reaktív desztillációjában alkalmaztam. Az illékonyabb komponensek (pl. acetol) a gőzben, illetve a gőz kondenzációjával nyert desztillátumban, a kevésbé illékonyak (glicerin és kondenzációs termékek) pedig a folyékony maradékban dúsulnak fel. A kísérleti berendezés sematikus képe a 24 . ábrán látható.

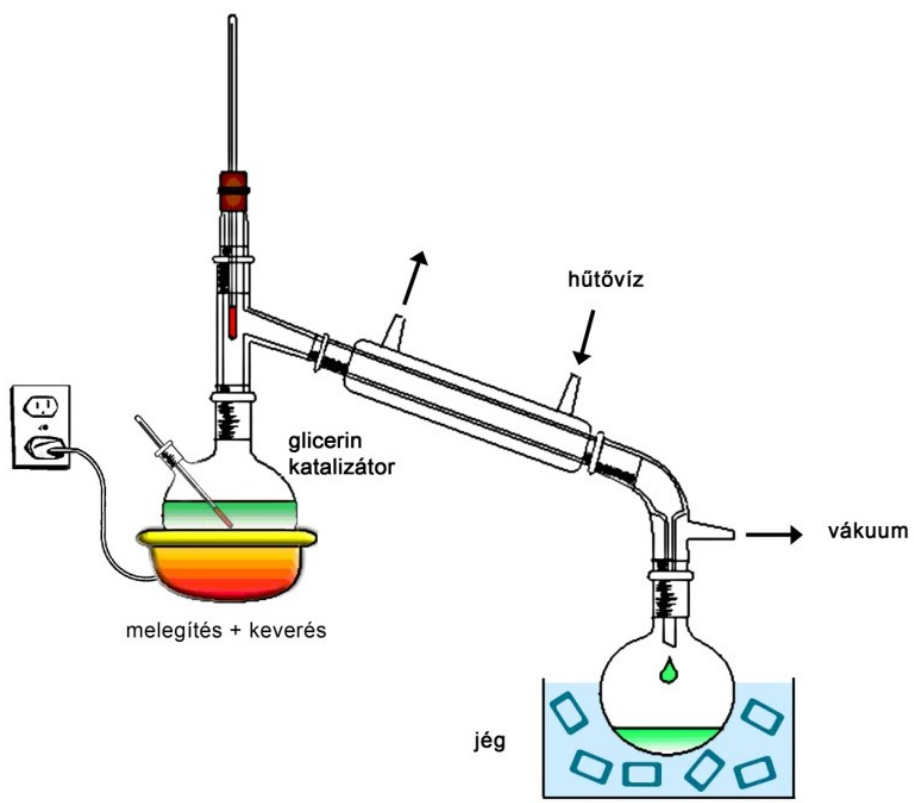

24. ábra: A kísérleti berendezés sematikus ábrája

Vizsgálataimk során a 87 \%-os tisztaságú glicerin átalakítását egy duplanyakú gömblombikban valósítottam meg a következő módon. Induláskor $50 \mathrm{~cm}^{3}$ glicerint töltöttem a reakcióedénybe, melyet folyamatosan melegítettem és kevertettem. A lombikhoz csatlakoztatott hütőben az elpárolgott komponensek kondenzálódtak (desztillátum), amit az ehhez kapcsolt, jéggel hütött gyüjtőlombikban fogtunk fel.

A $20-25 \mathrm{kPa}$ nyomást vízsugárszivattyú segítségével biztosítottam. A mérés kezdőpontjának azt tekintettem, mikor a 2 tömeg\% -nak megfelelő mennyiségü $(1,2 \mathrm{~g})$ katalizátort a glicerinhez adtam, és ezzel egy időben a fütést és a keverést (100 rpm) bekapcsoltam. A reakcióelegy és a gőzfázis hőmérsékletét folyamatosan regisztráltam. A desztillációs maradék hőmérséklete általában $240{ }^{\circ} \mathrm{C}$ környékén állandósult, amely hőmérsékletet 120 perc elteltével ért el. Így minden reakciót 2 órán át hagytam futni.

A reaktív desztilláció után a desztillátum és a maradék tömegét és térfogatát lemértem, eb- 
ből számoltam anyagmérleget. A desztillációs maradéktól centrifugálással (12 perc, 3200 rpm) választottam el a szilárd katalizátort, melyet ezután többször mostam, hogy a rajta megtapadt viszkózus desztillációs maradékot minél tökéletesebb mértékben eltávolítsam. Ezután szárítottam, majd hőkezeléssel kíséreltem meg a regenerálást. Sikeres esetben a használt és regenerált katalizátorok müködését további reakciókban teszteltem.

\subsubsection{Termékanalízis, gázkromatográf}

A desztillátum és a maradék gáz- és folyadékfázisának összetételét - utóbbit 10-20-szoros 2-propanollal történő hígítás után - Shimadzu GC2010 típusú, lángionizációs detektorral és SPB624 (Supelco, 20 m x 0.18 mm ID, $1 \mu \mathrm{m}$ film) kolonnával felszerelt gázkromatográffal (GC) határoztam meg. A minta bevitele a $250{ }^{\circ} \mathrm{C}$-os hömérsékletű mintaadagolóba történt, 1:10 splitarány alkalmazásával. A mérés során előbb 4 percen át tartottam a kolonnát $50{ }^{\circ} \mathrm{C}$ on, majd $10{ }^{\circ} \mathrm{C} /$ perc mértékben növeltem a hőmérsékletet $150{ }^{\circ} \mathrm{C}$-ra, ahol még további 10 percig tartottam.

A kromatogramokat a Shimadzu Scientific Instruments GC Solution Postrun Analysis nevü programjának segítségével értékeltem ki. Az így meghatározott csúcs alatti területekből a konverziót (13. egyenlet) (x) és a szelektivitást (14. egyenlet) (y) a következő módon számoltam:

$$
\begin{gathered}
x=100-\left[\frac{T_{g}}{T_{\ddot{o}}} \cdot 100\right], \\
y=\left[\frac{T_{i}}{\left(T_{\ddot{o}}-T_{g}\right)}\right] \cdot 100
\end{gathered}
$$

ahol $T_{g}$ a glicerin csúcs alatti területe $(\%)$,

$T_{i}$ az adott összetevő csúcs alatti területe (\%),

$T_{\ddot{o}}$ az összes detektált komponens csúcs alatti területeinek összege (\%). 


\section{Kísérleti eredmények és értékelésük}

\subsection{Röntgendiffrakció}

A röntgendiffraktogramokból információt nyerhetünk többek között a vizsgált anyag minőségéröl, szerkezetéröl és kristályosságáról. Ha a reflexiók intenzívek és keskenyek, az jól fejlett, nagy kristályok jelenlétét mutatja. Ezzel szemben a kevéssé intenzív, szélesebb reflexiók kisebb kristályokra, amorf jellegre utalnak.

\subsubsection{ZSM-5 zeolitok}

A használat előtti ZSM-5-katalizátorok röntgendiffraktogramjait hasonlítja össze a 25. ábra. Néhány, a későbbiekben tárgyalt különbségen túl, kizárólag a ZSM-5 szerkezetet meghatározó (PDF \# 37-0359) reflexiók [217] voltak megfigyelhetők.

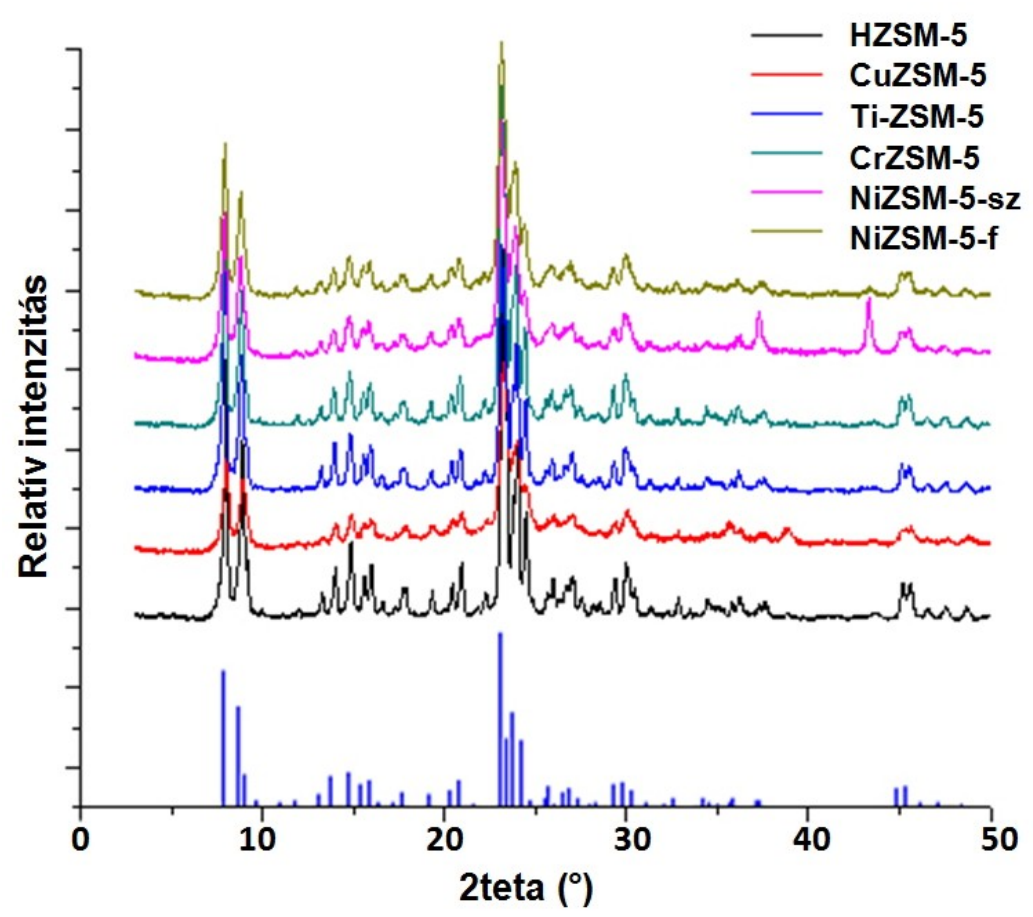

25. ábra: ZSM-5 katalizátorok röntgendiffraktogramjai a használat előtt

$\mathrm{Az}$ átlagos részecskeméretet a három legintenzívebb reflexió $2 \theta=7,9^{\circ} ; 8,8^{\circ}$ és $23,1^{\circ}(\mathrm{d}=$ $11,33 \AA ; 10,16 \AA ; 3,85 \AA$ ) alapján számítottam (2. táblázat).

2. táblázat: ZSM-5-katalizátorok átlagos részecskemérete (nm)

\begin{tabular}{lcccccc}
\hline minta & HZSM-5 & CuZSM-5 & Ti-ZSM-5 & CrZSM-5 & NiZSM-5-sz & NiZSM-5-f \\
\hline $\begin{array}{l}\text { részecske- } \\
\text { méret }\end{array}$ & 32,6 & 21,3 & 28,0 & 26,6 & 22,6 & 24,0 \\
\hline
\end{tabular}


A legnagyobb részecskemérete a HZSM-5-nek volt. Ezt követte az izomorf szubsztitúcióval előállított Ti-ZSM-5, majd a folyadékfázisú ioncserével létrehozott króm- és nikkeltartalmú minta, és végül a legkisebb szemcsemérettel a szilárdfázisú ioncserével szintetizált Ni-, illetve CuZSM-5 rendelkezett.

A HZSM-5-katalizátor a NH 4 ZSM-5 hőkezelése során alakult ki, azon további módosítást nem végeztem, viszont kiindulási alapját képezte a további katalizátorszintézisnek. Ezért nevezem olykor „módosítatlan” zeolitnak, megkülönböztetve a többi, egyéb fémionnal módosított mintától.

A Ti- és Cr-tartalmú zeolitok röntgendiffraktogramja nagyon hasonló a HZSM-5-éhez, az MFI szerkezetre jellemző szórásképen túl egyéb, határozott reflexiót nem látunk. Az intenzitás (az anyag kristályossága) a módosítók beépítésével is csak kismértékben csökkent.

Ezzel szemben a többi ion szerkezetbe vitele bizonyos változásokat idézett elő. Általában alacsony szögtartományban a HZSM-5 csúcsainak intenzitása érzékeny a csatornán belül lévő bármely részecskére [218]. A $2 \theta=10^{\circ}$ alatt a csúcsok intenzitáscsökkenése a csatornában lévő kationok jelenlétére utal. A fém bevitelének tulajdonítható intenzitáscsökkenést tapasztaltak Yaakob és munkatársai is [219].

A legjelentősebb változások a CuZSM-5 esetén történtek. Ezt a mintát az 3.2.1.5. fejezetben ismertetett módon szilárdfázisú ioncserével állítottam elő HZSM-5-öt használva alapként. Ennek megfelelően, a szórásképét a HZSM-5 diffraktogramjához hasonlítottam (26. ábra).

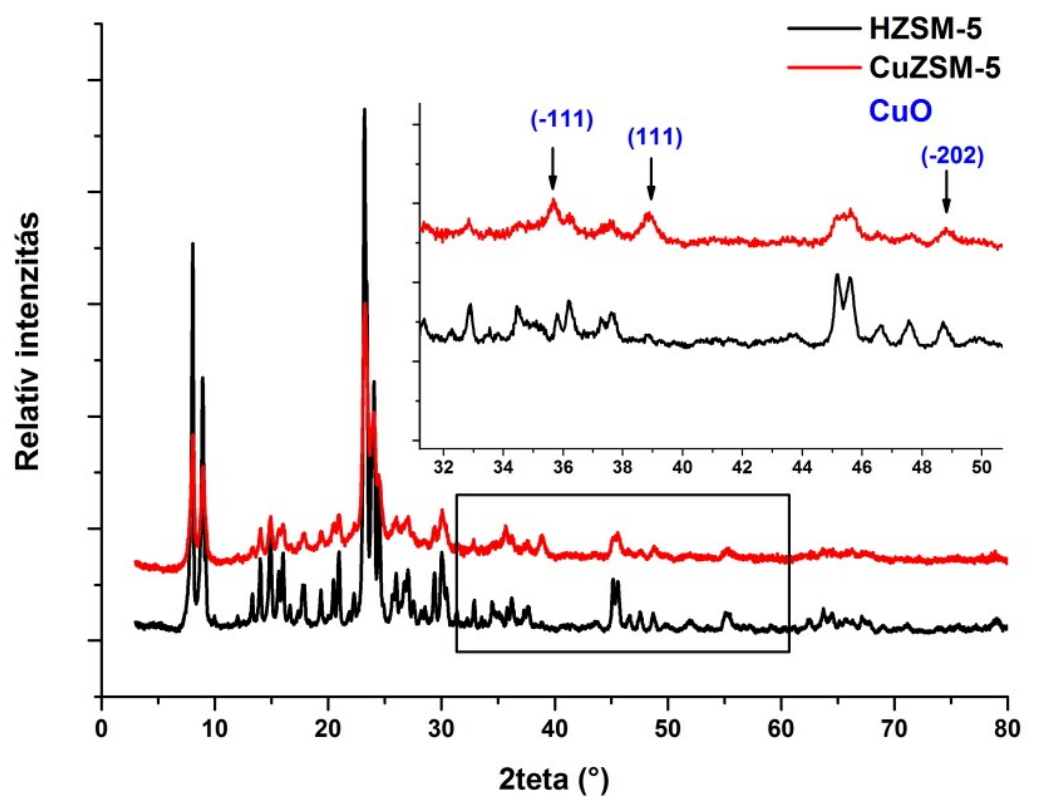

26. ábra: H-és CuZSM-5 röntgenfelvételeinek összehasonlítása

A katalizátorokat összevetve, a módosító bevitelének hatására a CuZSM-5 esetén volt a 
legnagyobb fokú intenzitáscsökkenés. A csökkenő és kiszélesedő reflexiók jól látszódnak már a $10^{\circ}<2 \theta<30^{\circ}$ szakaszon is, de az $50^{\circ}$ feletti $2 \theta$ tartományban a diffraktogram szinte teljesen ellaposodik. Ráadásul új reflexiók is megjelentek, melyek pozíciója azt bizonyítja, hogy a réz $\mathrm{CuO}$ formájában van jelen. A réz(II)-oxid adott irányba mutató rácssíkok közötti távolságát (d), és szemcseméretét (D) a 3. táblázat foglalja össze.

3. táblázat: A CuO megjelenése a használat előtti CuZSM-5-katalizátorban

\begin{tabular}{cccc}
\hline $\mathbf{2 \theta}\left({ }^{\circ}\right)$ & $\mathbf{d}(\mathbf{\AA})$ & $\mathbf{h k l}$ & $\mathbf{D}(\mathbf{n m})$ \\
\hline $\mathbf{3 5 , 6}$ & 2,52 & $(-111)$ & 21 \\
$\mathbf{3 8 , 8}$ & 2,31 & $(111)$ & 16 \\
$\mathbf{4 8 , 8}$ & 1,87 & $(-202)$ & 15 \\
\hline
\end{tabular}

A hasonló módon előállított NiZSM-5-sz esetén ugyanaz a jelenség (kiszélesedő reflexiók és egy új fázis megjelenése) figyelhető meg (27. ábra), mint a réztartalmú mintáknál.

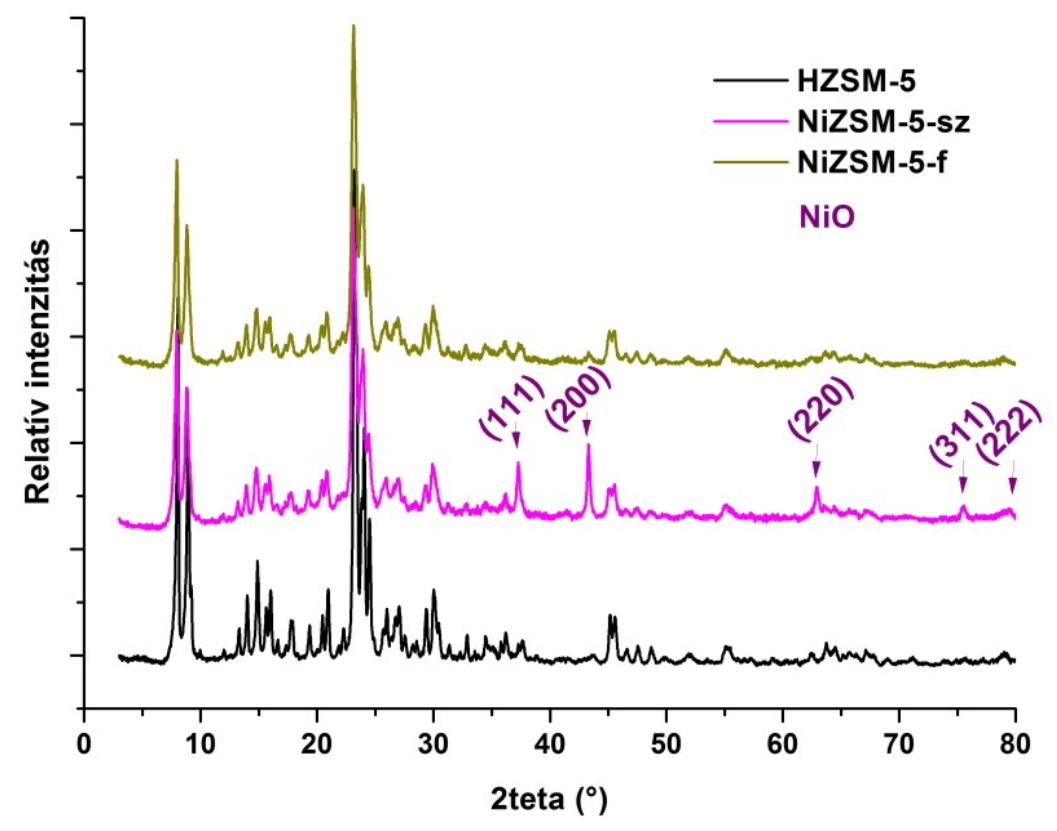

27. ábra: H-és NiZSM-5 röntgenfelvételeinek összehasonlítása

A $2 \theta=37,2^{\circ} ; 43,3^{\circ} ; 62,9^{\circ} ; 75,4^{\circ}$ és $79,4^{\circ}$-nál megjelenő éles reflexiók alapján arra következtethetünk, hogy a nikkel köbös bunzenitként $(\mathrm{NiO})$ jelenik meg. A kristályszerkezettel kapcsolatos paramétereket a 4. táblázat tartalmazza.

A folyadékfázisú ioncserével előállított NiZSM-5 (NiZSM-5-f) szórásképe annyiban különbözik az előzőétől, hogy a NiO reflexiói hiányoznak. A ZSM-5 fázisképét tekintve azonban ugyanazt a karakterisztikát kaptuk, mint a NiZSM-5-sz esetén. Azonos az kristálydegradáció mértéke, a csúcsok kiszélesedése (27. ábra). 
Kísérleti eredmények és értékelésük

4. táblázat: A NiO kristálytani paraméterei a szilárdfázisú ioncserével létrehozott NiZSM-5 esetén

\begin{tabular}{cccc}
\hline $\mathbf{2 \theta}\left({ }^{\circ}\right)$ & d $(\AA)$ & hkl & D (nm) \\
\hline $\mathbf{3 7 , 3}$ & 2,41 & $(111)$ & 27 \\
$\mathbf{4 3 , 3}$ & 2,09 & $(200)$ & 31 \\
$\mathbf{6 2 , 9}$ & 1,48 & $(220)$ & 25 \\
$\mathbf{7 5 , 4}$ & 1,26 & $(311)$ & 20 \\
\hline
\end{tabular}

A reakció után az elválasztott, mosott és szárított használt katalizátorok röntgendiffrakciós képét is felvettem, és összehasonlítottam a használat előtt készült felvételekkel.

Általánosságban minden mintáról elmondható, hogy a használat során kicsit csökkent a kristályossága. Ez leginkább a $2 \theta=7-18^{\circ}$ közötti csúcsok esetében nyilvánul meg, amit a folyadékfázisú ioncserével létrehozott NiZSM-5 példáján mutatok be (28. ábra).

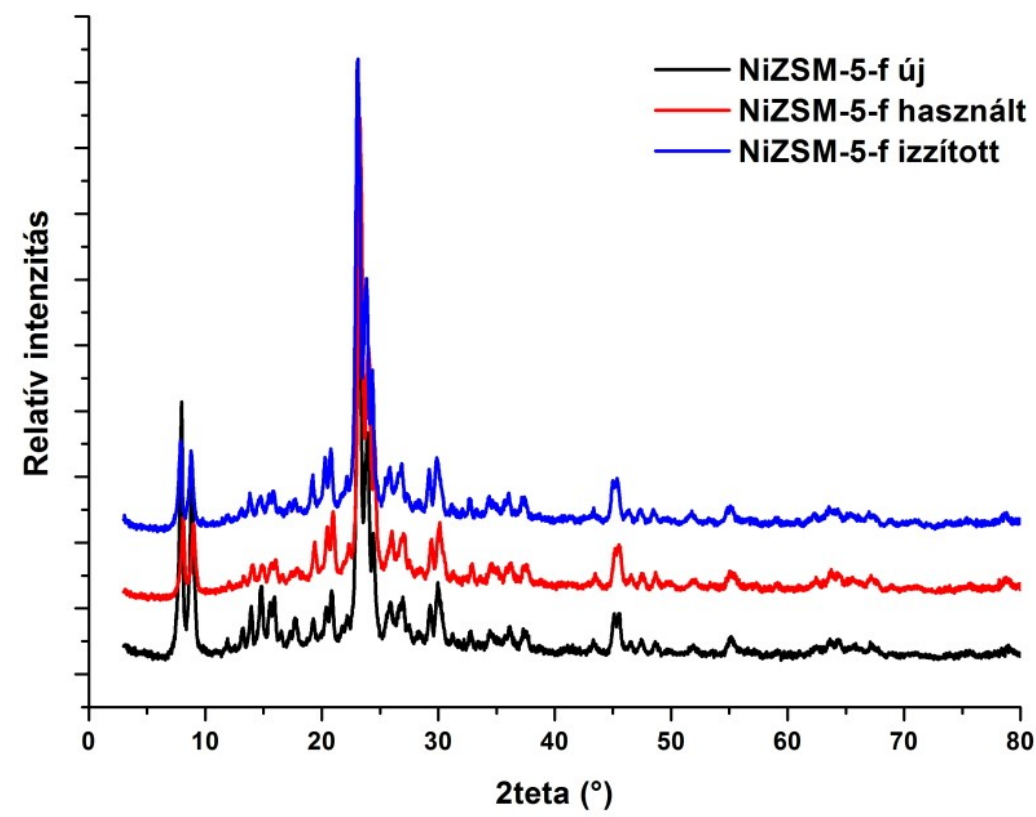

28. ábra: NiZSM-5 röntgendiffraktogramja a használat előtt, után és a regenerálást követően

A CuZSM-5 szerkezetében az intenzitáscsökkenésen túl egyéb változások is történtek.

5. táblázat: $\mathrm{A} \mathrm{Cu}_{2} \mathrm{O}$ kristálytani paraméterei a használt CuZSM-5 mintában

\begin{tabular}{cccc}
\hline $\mathbf{2 \theta}\left({ }^{\circ}\right)$ & d $(\AA)$ & hkl & D (nm) \\
\hline $\mathbf{3 6 , 5}$ & 2,46 & $(111)$ & 32 \\
$\mathbf{4 2 , 5}$ & 2,13 & $(200)$ & 26 \\
$\mathbf{6 1 , 4}$ & 1,51 & $(220)$ & 35 \\
$\mathbf{7 3 , 6}$ & 1,29 & $(311)$ & 28 \\
\hline
\end{tabular}


Eltűntek a CuO-ra jellemző reflexiók, és helyette újak jelentek meg, melyek jó egyezést mutatnak a $\mathrm{Cu}_{2} \mathrm{O}$ röntgendiffrakciós szórásképével (5. táblázat).

A $\mathrm{CuO}$ tehát redukálódott a használat során $\mathrm{Cu}_{2} \mathrm{O}$-dá. Ezt az átalakulást a színváltozás is alátámasztja: a fekete katalizátorból rózsaszínes-mályvás színű anyag keletkezett.

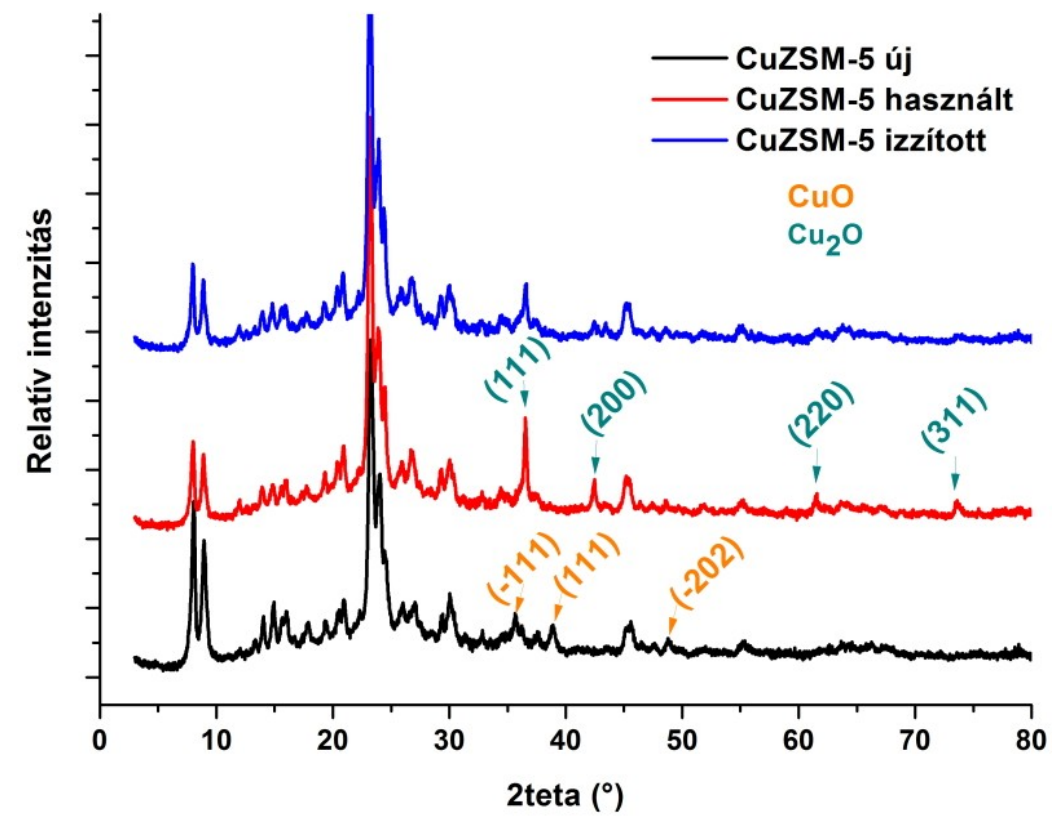

29. ábra: Réz-oxid átalakulásai a CuZSM-5-ben

A $600{ }^{\circ} \mathrm{C}$-os hőkezelés hatékony regenerálási módszernek mutatkozott. A kristályosság minden esetben kismértékben nőtt, illetve a $\mathrm{CuZSM}$-5-nél a $\mathrm{Cu}_{2} \mathrm{O}$ egy része visszaalakult CuO-dá (29. ábra).

A mosott-hőkezelt minták tehát alkalmasak voltak arra, hogy ismételt tesztnek vessem őket alá a már ismert dehidratációs reakcióban.

\subsubsection{Raney-nikkel}

A Raney-Ni minták esetén a szokásos módon felvettem a röntgendiffrakciós szórásképet, majd azonosítottuk a reflexiókat, és számoltam a különböző paramétereket. Mivel a reflexiók azonosítása sokáig magánál a feltalálócsoportnál is nehézségekbe ütközött, így az értékelésben ők nyújtottak némi segítséget.

A fázisösszetételt a MTA Kémiai Kutatóközpontjában határozták meg ún. teljes profilillesztéses módszerrel. A program a polikristályos porminta feltételezett összetételéből kiszámítja az ennek megfelelő diffraktogramot, és összehasonlítja a mintán mért szórásképpel. A mért és számított röntgendiagram különbségeinek minimalizálásával finomítja a modell para- 
métereit, míg elfogadható egyezést kap (eltérés $<5 \%$ ), és így a több kristályos fázisból álló minta esetén az egyes fázisok mennyiségét is meghatározza.

A használat előtti 222A és 222B szórásképe (30. ábra) és fázisösszetétele (31. ábra) gyakorlatilag megegyezik, míg a 222C minta ezektől eltér.

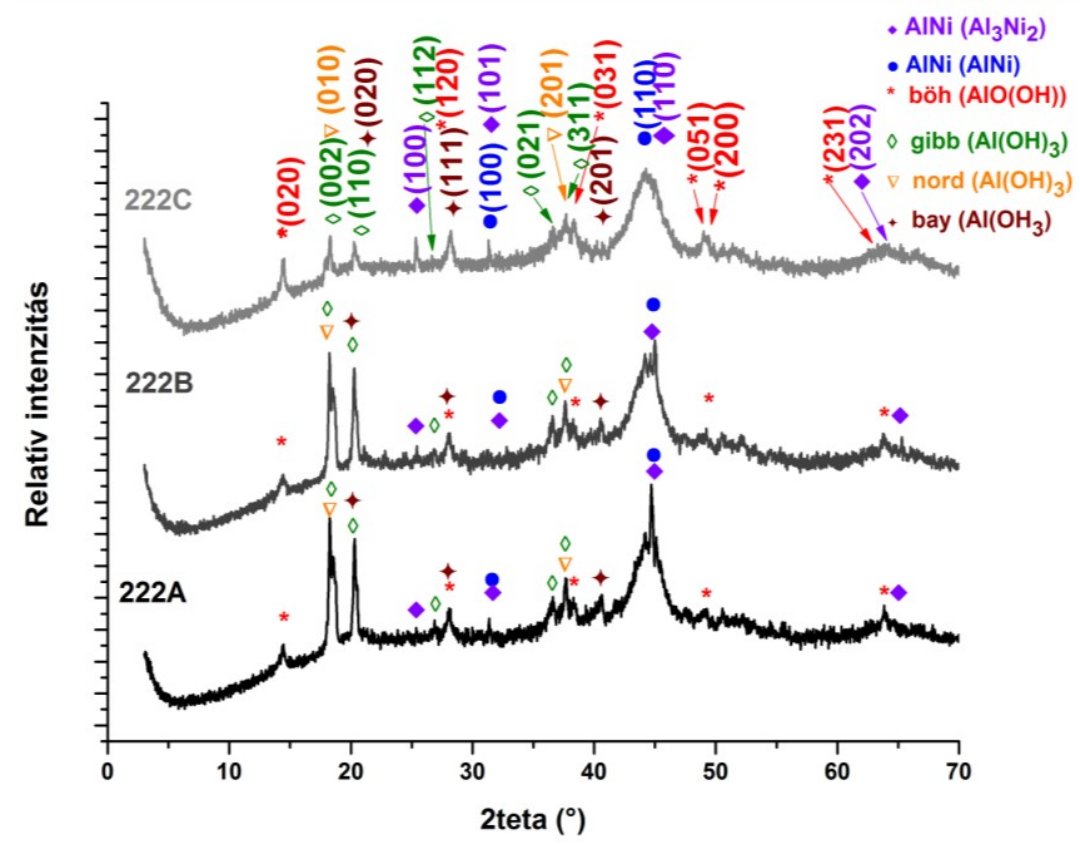

30. ábra: A RNi-222A, -222B és -222C röntgendiffraktogramjai

$\mathrm{AlNi}=$ alumínium-nikkel $\left(\mathrm{Al}_{3} \mathrm{Ni}_{2}, \mathrm{AlNi}\right)$; böh=böhmit; gibb=gibbsit; nord=nordstrandit; bay=bayerit

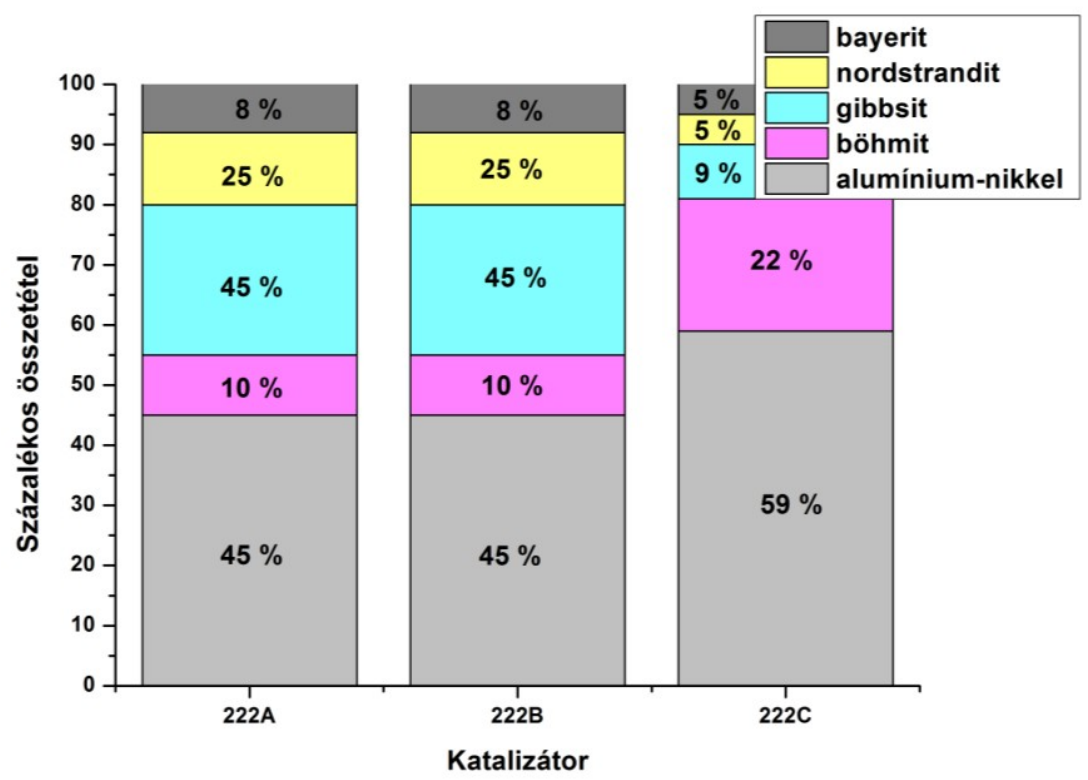

31. ábra: 222A, 222B és 222C fázisösszetétele

Ezt a megállapítást a nitrogén-adszorpciós és termogravimetriás (lásd a 4.2.2 illetve 4.3.2 
fejezetben) vizsgálatok is megerősítették. A 222A és 222B előkezelési hőmérsékletének megfelelő tartományban $\left(50-120^{\circ} \mathrm{C}\right)$ tehát ezekkel a módszerekkel kimutatható változás nem történt, míg a $120-320{ }^{\circ} \mathrm{C}$ hőmérsékleten vízvesztéssel a gibbsit, bayerit és nordstrandit egy része böhmitté alakult át, így a $320^{\circ} \mathrm{C}$-on hőkezelt $222 \mathrm{C}$ mintában a böhmit a fó nemfémes komponens, ugynakkor megnőtt az alumínium-nikkel ötvözet aránya is. Számos tanulmány [220-225] bizonyítja, hogy a fenti átalakulások ebben a hőmérséklet-tartományban történnek.

Annak érdekében, hogy a termikus vizsgálatok eredményeit pontosabban értelmezhessük, a katalizátorokat $600{ }^{\circ} \mathrm{C}$-on hőkezeltük, majd az így kapott minták szerkezetét összehasonlítottuk a kiindulási anyagokéval. Tekintve, hogy a 222A, 222B és 222C között csak az elökezelés hőmérsékletében van különbség, így nem meglepő, hogy az ennél jóval magasabb hőfokon történő égetés hatására kapott minták röntgendiffrakciós szórásképe teljesen azonos. Mivel a kezelés hőmérsékletében, és így a diffraktogramban is a 222C áll hozzá a legközelebb, ezért szerkezetét azzal összehasonlítva mutatom be (32. ábra).

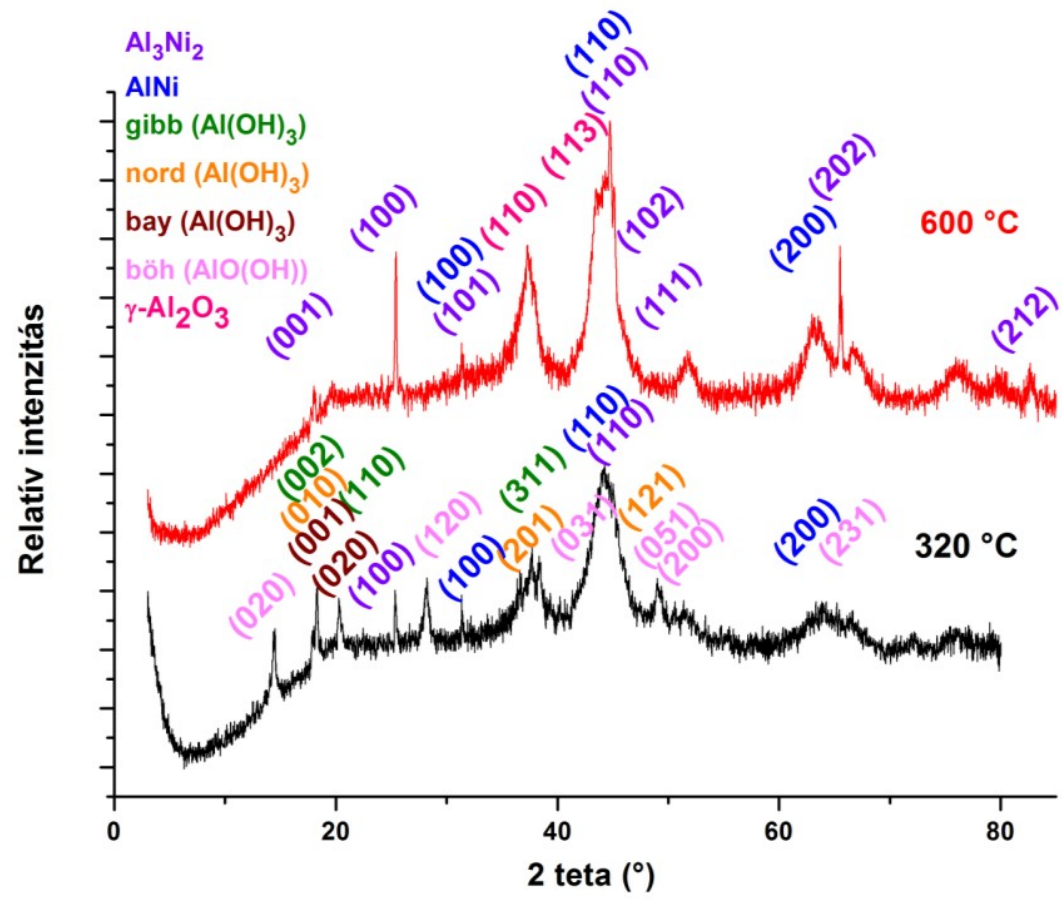

32. ábra: Raney-nikkel $320^{\circ} \mathrm{C}(=\mathrm{RNi}-222 \mathrm{C})$ és $600{ }^{\circ} \mathrm{C}$ hőkezelés után gibb=gibbsit; nord=nordstrandit; bay=bayerit; böh=böhmit

Az irodalomból ismeretes [220, 226, 227], hogy a böhmit $450-520{ }^{\circ} \mathrm{C}$ körül átalakul $\gamma$ $\mathrm{Al}_{2} \mathrm{O}_{3}$-dá. A diffraktogramon jól látszik, hogy valóban, az alumínium-trihidrátok és a böhmit eltűntek, viszont megjelentek az alumínium-oxidra jellemző reflexiók. Az alumínium-nikkel ötvözetek már a 222C-ben is jelentős arányban voltak jelen, de a hordozó átalakulásával még 
hangsúlyosabbá váltak. A reflexiók keskenyek, ami nagyfokú kristályosságra utal. $\mathrm{Az}_{\mathrm{Al}} \mathrm{Al}_{3} \mathrm{Ni}_{2}$ $2 \theta=25,4^{\circ}$-nál lévő (100) reflexiója alapján a kristályméret 48,41-röl 52,96 nm-re nőtt.

A reakció során a 222-es sorozat tagjainál - korábban nem tapasztalt - szétválás volt megfigyelhető. A mosott és ülepített használt katalizátort egy egyszerü mágnes segítségével két részre tudtam szeparálni. A ferromágneses, sötét színü rész elválasztása után egy szürke, megszáradva finom porszerü anyag maradt vissza (33. ábra).

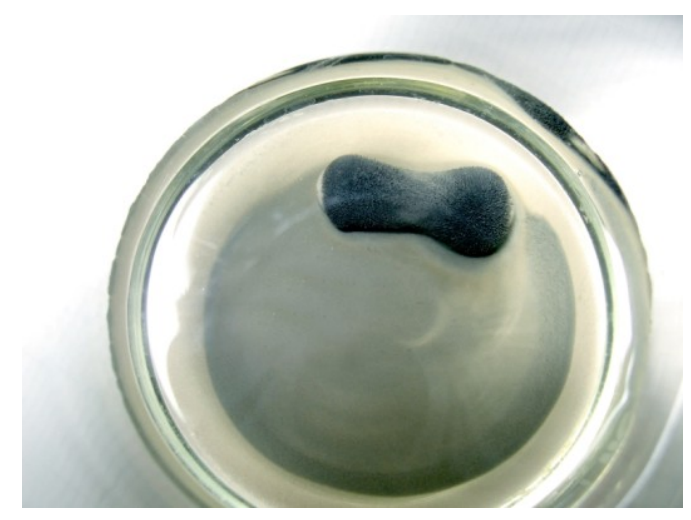

33. ábra: Reakció során szétvált RNi-222

Ezek röntgenfelvételeit összehasonlítottam az eredeti, használatlan katalizátorok diffraktogramjaival (34. ábra), melyekből egyértelmüen megállapítható, hogy a szétvált mintában a ferromágneses részt többnyire a fémes, Al-Ni fázisok jelentették, míg a főzőpohárban maradt komponensek a nem mágnesezhető Al-oxihidrátok.

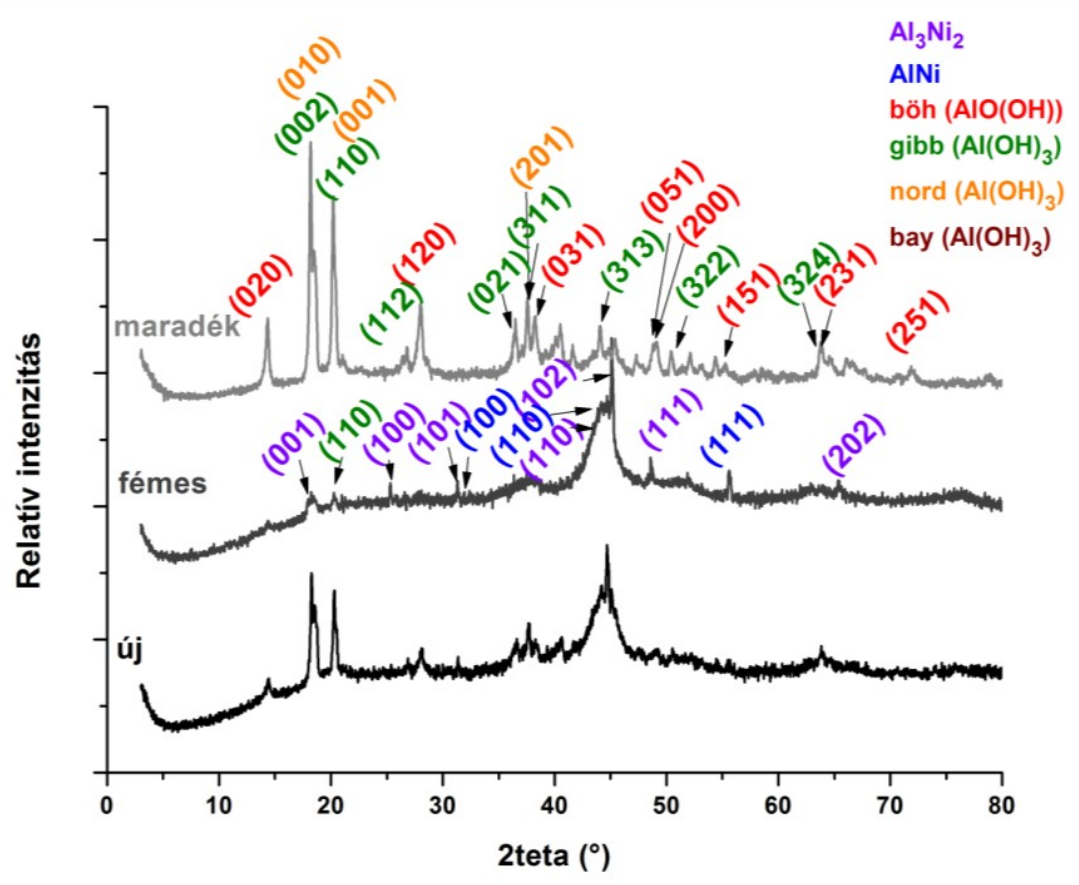

34. ábra: RNi-222A röntgendiffrakciós szórásképe a használat előtt és után böh=böhmit; gibbs=gibbsit; nord=nordstrandit; bay=bayerit 
Az egyszerűség kedvéért a még használatlan mintákat a továbbiakban új néven fogom említeni. Bár a klasszikus értelemben nem beszélhetünk hordozó-hordozott kapcsolatról, helyenként az oxihidrátokra használom a hordozó kifejezést. A reakció során szétvált minták mágnesezhető részét fémes, míg a főzőpohárban maradó, nem mágnesezhető részét maradéknak nevezem. Mivel az elválasztás során a fémes fázisba is került az alumínium-nikkel mellé a hordozó szerepét betöltő oxihidrát, így a maradékban nincs jelen a hordozó teljes mennyisége. Ezért volt szükség a több elnevezés használatára, hogy ezek jól elkülöníthetők legyenek.

A szétvált minta fázisösszetétel-változását a 222A minta esetén a 6. táblázat foglalja össze. Első közelítésben elmondható, hogy a maradékot kizárólag Al-oxihidrátok alkotják, míg a redukált, nikkeles-intermetallikus rész a fémes fázisban dúsult fel.

6. táblázat: Reakció során bekövetkezett fázisösszetétel-változás (\%) a RNi-222A esetén

\begin{tabular}{lcccccc} 
222A & SUM & alu-ni & böh & gibbs & nord & bay \\
\hline új & 100 & 45 & 10 & 25 & 12 & 8 \\
maradék & 100 & 0 & 25 & 55 & 20 & 0 \\
fémes & 100 & 74 & 10 & 16 & 0 & 0
\end{tabular}

alu-ni= alumínium-nikkel $\left(\mathrm{Al}_{3} \mathrm{Ni}_{2}+\mathrm{AlNi}\right)$; böh=böhmit $(\mathrm{AlO}(\mathrm{OH}))$; gibbs=gibbsit $\left(\mathrm{Al}(\mathrm{OH})_{3}\right)$; nord=nordstrandit $\left(\mathrm{Al}(\mathrm{OH})_{3}\right)$; bay=bayerit $\left(\mathrm{Al}(\mathrm{OH})_{3}\right)$

A 212 típusú katalizátor (szilíciumba ágyazott Ni-szilicid) röntgendiffraktogramján jól látszanak a nikkel-szilicidre (+) és a szilíciumra (*) jellemző reflexiók (35. ábra).

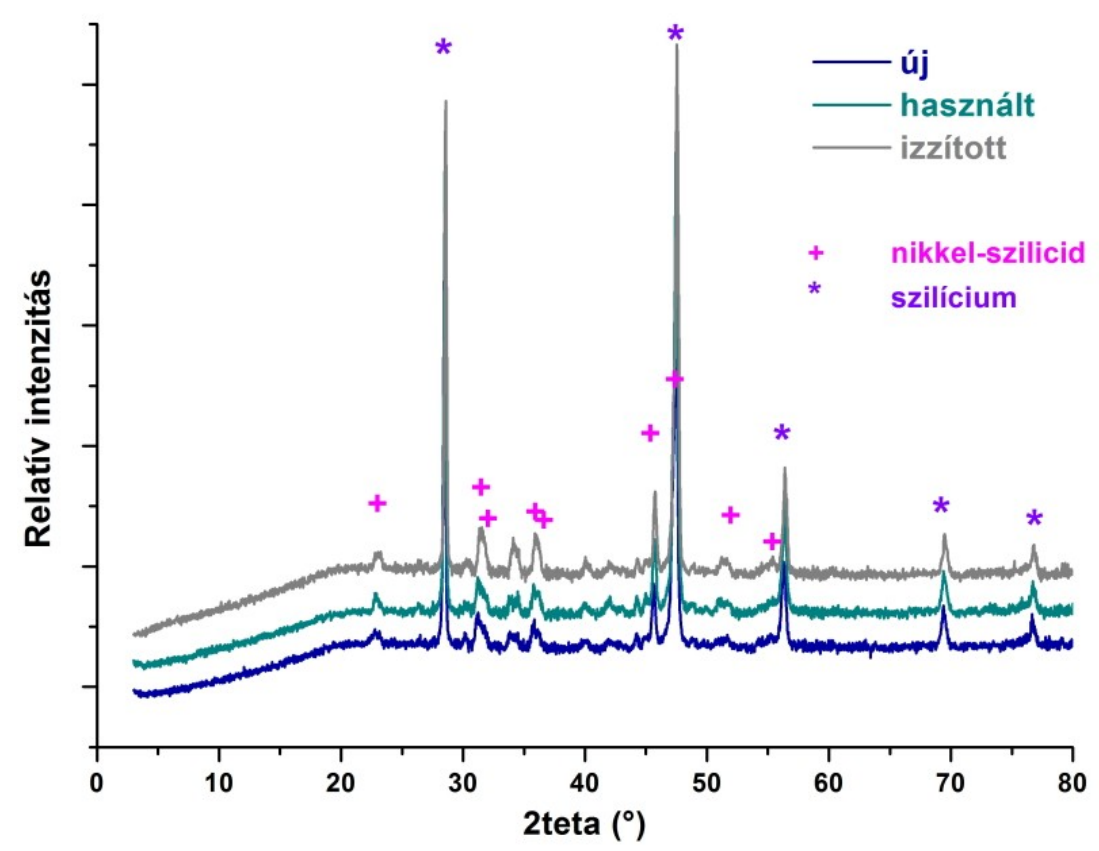

35. ábra: RNi-212 röntgendiffraktogramja használat előtt, után és az izzítást követően 
Látható az is, hogy a kiindulási anyag gyakorlatilag azonos a használttal, lényeges fázisátalakulás, intenzitásváltozás nem történt. A 212-es minta nem vált szét, azért mert abban nincs Al-oxihidrát „hordozó”, csak fémes-intermetellikus fázisok. A Si (50\%) mellett nikkelszilicid (30\%) és egy ismert referencia-adatokkal nem azonosítható fázis alkotja a mintákat.A $600{ }^{\circ} \mathrm{C}$-os hőkezelés semmifajta változást nem idézett elő a 212 minta kristályszerkezetében, ami összhangban van azzal, hogy a termogravimetriás mérések sem mutattak tömegcsökkenést az adott hőmérséklet-tartományban. Ebböl következően megfelelő módszernek adódott, hogy a használat után ilyen módon regeneráljam a mintákat.

Ezzel szemben a 222-es sorozat elemeinek esetén a szétválás miatt, szóba sem jöhetett a regenerálás, legalábbis olyan módon biztosan nem, hogy a Raney-típusú szerkezetet visszakapjuk.

\subsubsection{Az LDH-minták röntgendiffrakciós analízise}

Amint az a 2.5.3.1. fejezetben szerepelt, a réteges kettős hidroxidok egy részét összefoglaló néven szokták hidrotalcitoknak is nevezni. Bár az általam katalizátorként használt anyagok az izzítás során elvesztették réteges szerkezetüket és keverékoxidokká váltak, azt később a reakcióban való használat során képesek voltak visszanyerni. Ezért attól függetlenül, hogy az adott anyag éppen lamellás szerkezetetben jelenik-e meg vagy sem, használom rá a hidrotalcit kifejezést is.

Mivel a hidrotalcitok réteges szerkezetűek, így esetükben néhány dolog módosul a röntgenvizsgálatokról általánosságban leírtakhoz képest.

Tekintve, hogy a tanulmányozott LDH-k romboéderes kristályszerkezetűek, így csak kétféle rácsparaméterről beszélhetünk ( $a$ és $c$ ), illetve igaz rá, hogy $(-\mathrm{h}+\mathrm{k}+\mathrm{l})=3 \mathrm{n}$. A (003), (006), (009), (012), (015) reflexiók általában $2 \theta=5-60^{\circ}$ tartományban, míg a (110) és (113) csúcsok rendszerint $2 \theta=60^{\circ}$ után jelennek meg [190].

A diffraktogramon a $\mathrm{d}_{003}\left(\mathrm{c}_{0}\right)$ reflexió jelenik meg elsőként, $2 \theta=2^{\circ}$ és $12^{\circ}$ között, az anion fajtájától függően. Ennek a háromszorosa adja a $c$ rácsparamétert, ami az ismétlődő rétegek távolságát jelenti (repeat layer distance), azaz egy brucitszerü réteg és egy „interlayer” együttes vastagságát: $\mathrm{c}=3 \mathrm{~d}_{003}=3 \mathrm{c}_{0}[190,228]$.

A rétegek közi távolságot (d-spacing) szintén származtathatjuk a (003) reflexióból. A két LDH sík közti távolságot nagyban befolyásolja az interkalált anionok mérete. „Galériamagasságnak" (gallery height) nevezik azt a teret, amit a rétegközi térből az anion elfoglal. Ezt úgy kapjuk meg, hogy rétegközi térből kivonjuk az átlagos rétegvastagságot [190].

Fontos információ az a rácsparaméter, mely az LDH kation réteg ugyanazon oldalán lévő 
két szomszédos hidroxilcsoport vagy a két legközelebbi fémion közti távolságot (részecskeátmérő) adja meg. Ezt általában $2 \theta=61-64^{\circ}$ körül megjelenő (110) reflexióból nyerhetjük a következőképp: $a=2 \mathrm{~d}_{110}[190,229]$.

A korábban említett módon pedig a Scherrer-egyenlet segítségével a kristályméret számítható.

Felvettem a hökezelés előtti, „nyers” (,,as-prepared”) MgAl-hidrotalcit röntgendiffrakciós szórásképét. A kapott reflexiók megfeleltethetőek a $\mathrm{Mg}_{6} \mathrm{Al}_{2}(\mathrm{OH})_{16}\left(\mathrm{CO}_{3}\right) \cdot 4 \mathrm{H}_{2} \mathrm{O}$ (hidrotalcit, HT) és a MgO (perikláz) (PDF \# 71-1176) [230] reflexióinak (36. ábra/A).
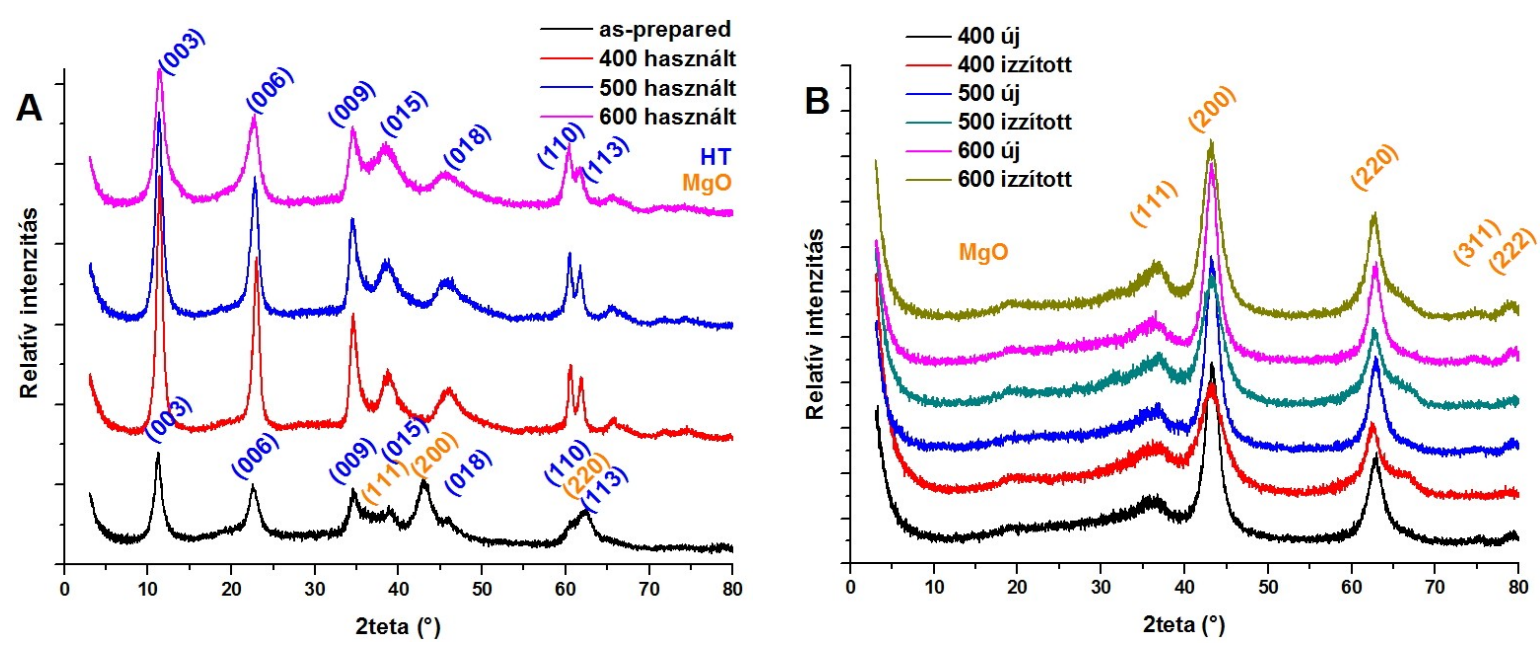

36. ábra: MgAl-hidrotalcit hőkezelés elött és használat után (A), illetve hökezelés és izzítás után (B)

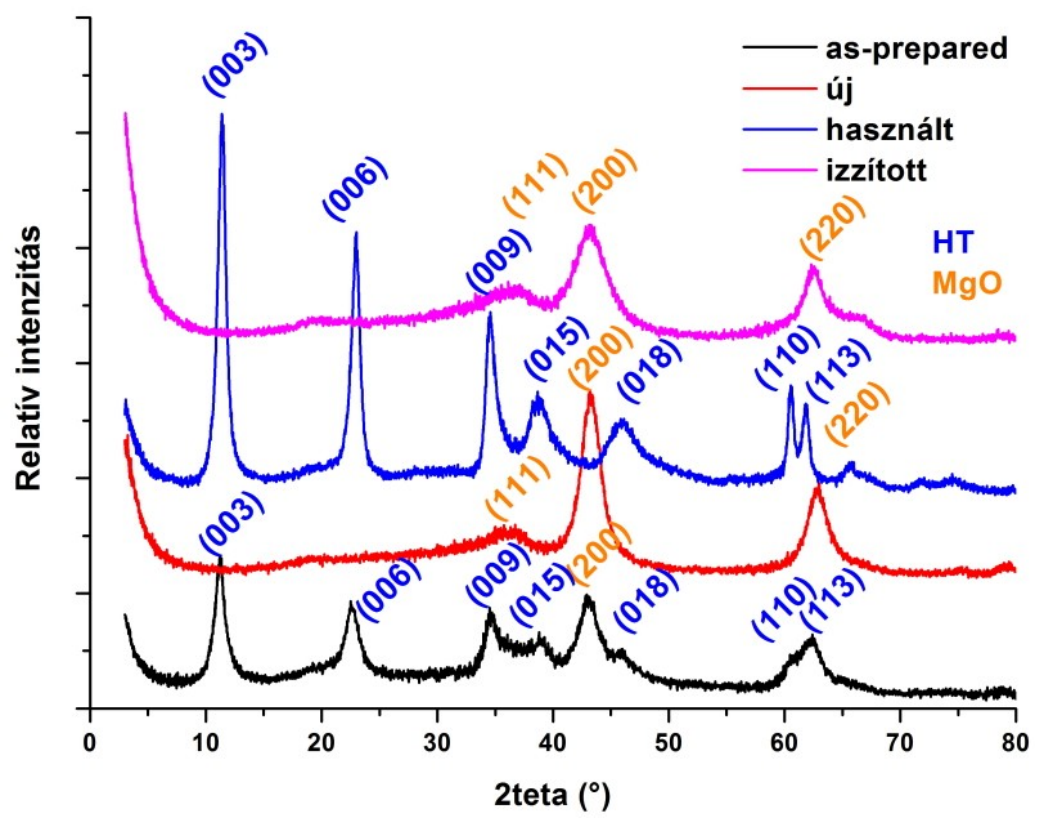

37. ábra: MgAl-hidrotalcit röntgenfelvétele hökezelés elött és után, használat után és az izzítást követően 
A mintákat 400, 500, illetve $600{ }^{\circ} \mathrm{C}$-os hökezelésnek vetettem alá (új). A röntgenfelvételek azt mutatták, hogy - a fenti tartományon belül maradva - az alkalmazott hőmérséklettől függetlenül minden esetben kizárólag $\mathrm{MgO}$ (perikláz) keletkezett (36. ábra/B). Az alumíniumoxid reflexiói nem láthatóak, ami arra utal, hogy az $\mathrm{Al}^{3+}$ kationok a MgO szerkezetében diszpergáltan helyezkednek el, anélkül, hogy spinell $\left(\mathrm{MgAl}_{2} \mathrm{O}_{4}\right)$ részecskék képződtek volna. Hasonló eredményre jutattak Zeng és munkatársai is [229].

Első látásra meglepőnek tünhet, hogy a használt MgAl-LDH-katalizátorok röntgenfelvételeit összevetve a hökezelés elötti használatlan („as-prepared”) mintáéval nagy hasonlóságot lehet látni (36. ábra/A és 37. ábra). Figyelembe véve, hogy a glicerin átalakulásakor vízkilépés történik, valójában várható volt, hogy a réteges szerkezet részben helyreálljon. Az azonban meglepő, hogy a szerkezet teljes mértékben helyreállt, ráadásul még a kristályosság is nőtt az ,as-prepared” mintához képest. Különbséget jelentett még az is, hogy a használt katalizátorból a kis mennyiségü perikláz csúcsai (különösen $2 \theta=43,0^{\circ}$ ) eltüntek.

A kapott eredmények megerősítik a mások [185, 187, 188] által is leírtakat, miszerint az emlékező szerkezetnek köszönhetően vízfelvétellel akár az 500-600 ${ }^{\circ} \mathrm{C}$-on hőkezelt minta is képes visszaállítani réteges szerkezetét, és hogy az együttes lecsapás módszerével előállított hidrotalcit estén a rehidratálással nő a kristályosság [185].

$\mathrm{Az}$ előkezeléskor használt hőmérsékleten való izzítással regenerálva a használt MgAlkatalizátorokat (izzított) - kis intenzitáscsökkenéssel - visszakaptam a használatlan (új) minta szerkezetét (36. ábra/B és 37. ábra).

A módosított minták szintézisekor minden esetben a Mg- illetve Al-nitrátnak 10 \% -át cseréltem ki a megfelelő fém-nitrátra. A módosításra a különböző minták eltérő módon reagáltak.

A Ni-HT örizte meg leginkább a hidrotalcitszerkezetet. $\mathrm{A} \mathrm{Ni}^{2+}$ ionok többsége - részben helyettesítve a $\mathrm{Mg}^{2+}$-ot - beépült a hidrotalcitszerkezetbe, ugyanakkor kisebb arányban megjelentek a magnézium- és a nikkel-oxidra jellemző reflexiók is (38. ábra/A), melyek a hőkezelés során a hidrotalcit csúcsainak eltünésével meghatározóvá váltak (38. ábra/B).

Csakúgy, mint a módosítatlan hidrotalcitok esetén, a hőkezelés előtti és a használt katalizátorok hasonlósága szembetűnő, a réteges szerkezet teljes mértékben helyreállt a glicerin átalakulásakor kilépő víznek köszönhetően. A használt Ni-HT-500 és Ni-HT-600 minták képein a $\mathrm{NiO}$ csúcsai váltak hangsúlyossá (38. ábra/A).

A használt minták megfelelő hőmérsékleten történő izzítása után a hőkezelt, használatlan mintákéval azonos szóráskép rajzolódott ki, vagyis a regenerálás sikeres volt (38. ábra/B). A diffraktogramokon $\mathrm{MgO}$ és $\mathrm{NiO}$ keveréke, valamint jól diszpergált alumínium látható. 

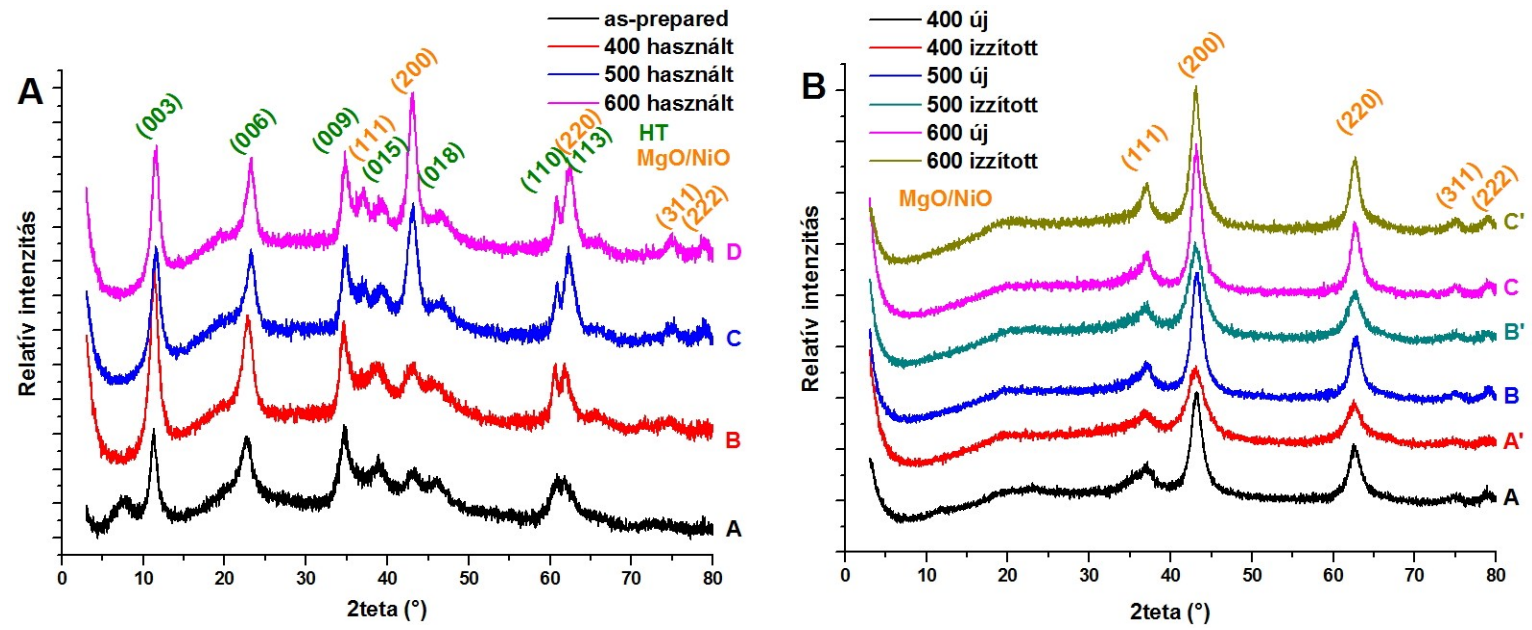

38. ábra: NiMgAl-hidrotalcit szórásképe hőkezelés előtt és használat után (A), illetve hőkezelés és izzítás után (B)

Amint azt láthattuk, a MgAl és a nikkellel módosított, hőkezelés előtti, és használat utáni minták a hidrotalcitok szórásképét mutatták. A (003) reflexió alapján kiszámoltam a részecskeméretet és a bázislap-távolságot. A kapott értékek (7. táblázat) hozzávetőlegesen megfelelnek a mások [186, 229, 231, 232] által is tapasztaltaknak. A használat során a rétegszerkezet regenerálódása, illetve a Ni beépítése kismértékü csökkenést okozott a rácssík-távolságokban és esetenként a részecskeméretben.

7. táblázat: $\mathrm{MgAl}$ - és NiMgAl-hidrotalcit részecskemérete /D $(\mathrm{nm}) /$ és rácssík-távolsága /d $(\AA) /$

\begin{tabular}{lcccccccc}
\hline & \multicolumn{2}{c}{ as-prepared } & \multicolumn{2}{c}{ 400-használt } & \multicolumn{2}{c}{ 500-használt } & \multicolumn{2}{c}{ 600-használt } \\
\hline HT & D & $\mathbf{d}_{\mathbf{0 0 3}}$ & $\mathbf{D}$ & $\mathbf{d}_{\mathbf{0 0 3}}$ & $\mathbf{D}$ & $\mathbf{d}_{\mathbf{0 0 3}}$ & $\mathbf{D}$ & $\mathbf{d}_{\mathbf{0 0 3}}$ \\
$\mathbf{M g A l}$ & 7,87 & 7,86 & 7,98 & 7,82 & 7,69 & 7,80 & 7,57 & 7,76 \\
$\mathbf{N i}$ & 7,74 & 7,84 & 7,89 & 7,77 & 7,70 & 7,75 & 7,61 & 7,72 \\
\hline
\end{tabular}

A többi (Cu-, Cr-, $\mathrm{CuCr}-\mathrm{HT})$, hőkezelés előtti minta kevésbé kristályos, a reflexiók kiszélesednek, intenzitásuk csökken, mégis jól felismerhető a hidrotalcit szerkezete. A hőkezelés során a $\mathrm{MgO}$ reflexiói mellett a módosító fém jelenléte is látszik (39. ábra). Ez különösen a réztartalmú minták esetén feltünő, mert a $\mathrm{CuO}$ reflexióinak helye jelentősen eltér a $\mathrm{MgO}$-étól.

A CuMgAl-HT esetén a hőkezelt, használatlan katalizátorokon kirajzolódnak a MgO és a $\mathrm{CuO}$ [233] jellemző reflexiói, viszont a regenerálásként izzított mintán már a $\mathrm{CuO}$ csúcsai szinte egyeduralkodók $(40$. ábra/B). Ebben az esetben tehát a regenerálásként alkalmazott izzítással nem kaptam vissza a kiindulási szerkezetet.

A CuMgAl-hidrotalcit a hőkezelés elött főképp a hidrotalcit röntgendiffrakciós szórásképét mutatta. A fémionokkal nem módosított hidrotalcittal és a nikkeltartalmú mintákkal ellentét- 
ben a használat során elsősorban nem a lamellás szerkezet helyreállását említeném meg, hiszen az arra jellemző csúcsok csak nagyon kevéssé kivehetők a felvételen. A réz különböző oxidációs állapotban $\left(\mathrm{Cu}_{2} \mathrm{O}, \mathrm{Cu}\right)$ való megjelenése azonban hangsúlyos volt (40. ábra/A). $\mathrm{Az}$ együttes lecsapásssal kapott CuMgAl-HT szerkezetének kalcinálás során történő összeomlását, és a $\mathrm{CuO}$ nagyobb részecskéken végbemenő szintereződését tapasztalták Yuan és munkatársai is [228].

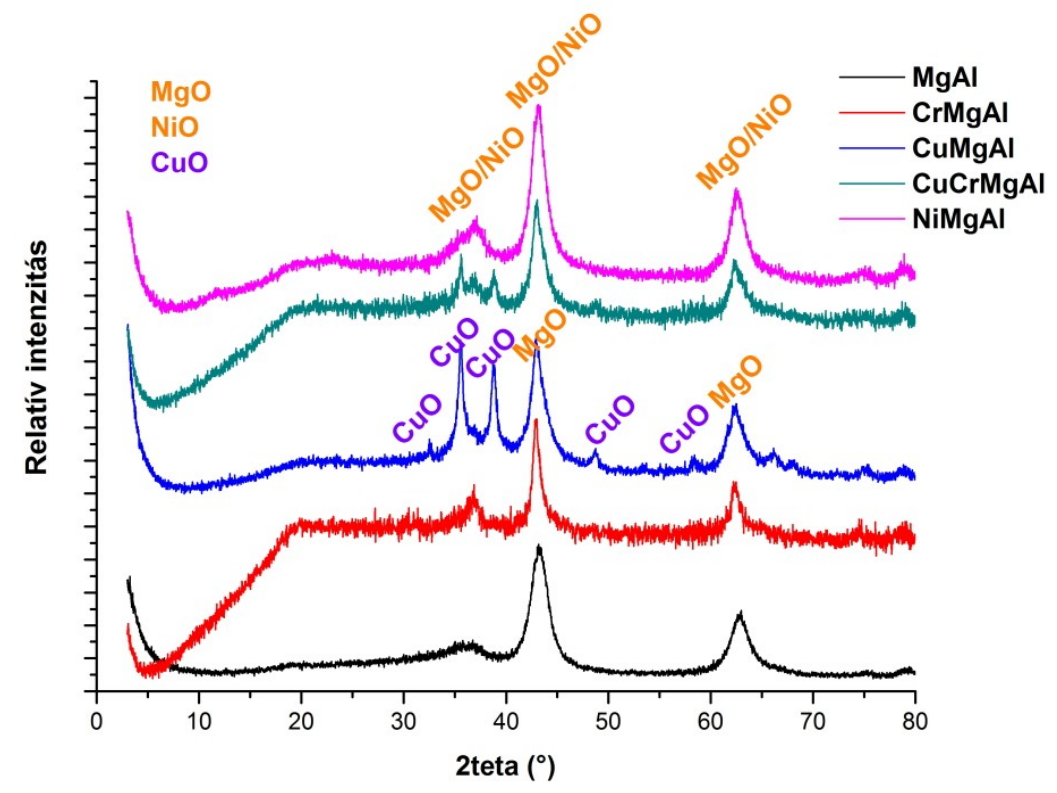

39. ábra: Hidrotalcitok szórásképe a $400{ }^{\circ} \mathrm{C}$-os hökezelés után
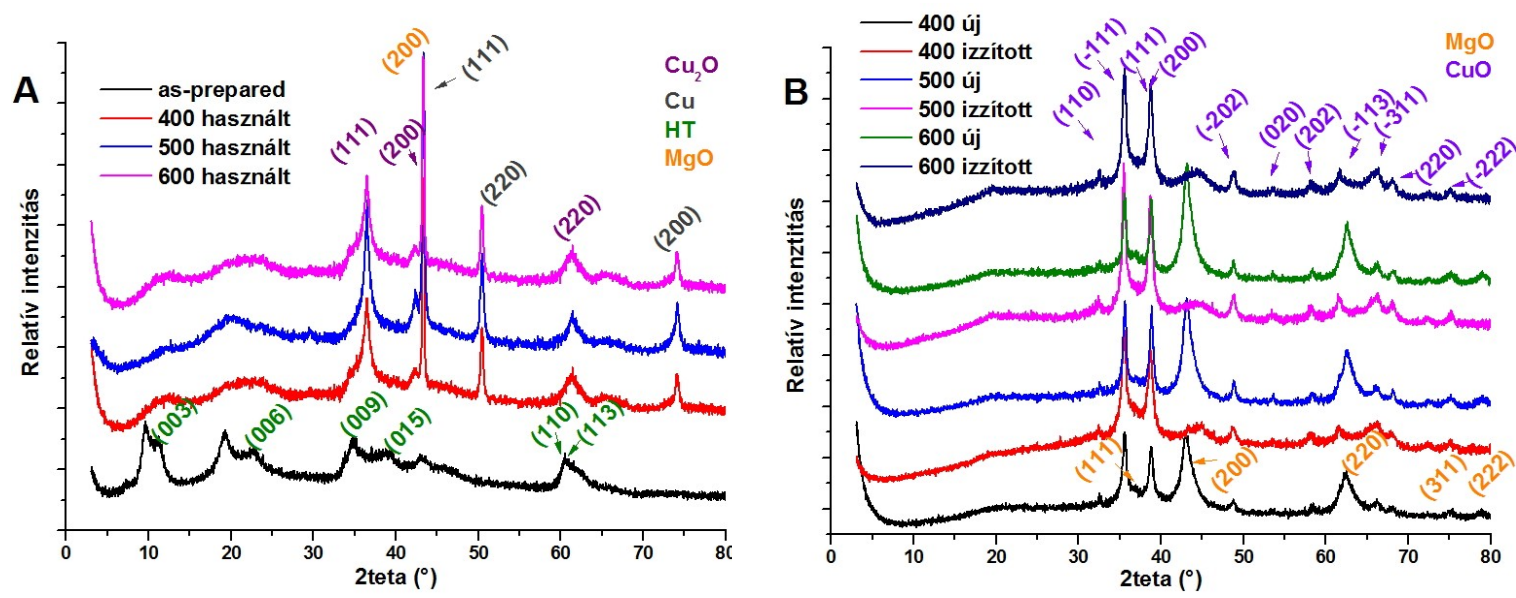

40. ábra: CuMgAl-hidrotalcit szórásképe hőkezelés előtt és használat után (A), illetve hőkezelés és izzítás után (B)

A Cr-HT nemcsak a használatlan minta röntgenfelvételében, de aktivitásában és szelektivitásában is hasonló volt a módosítatlan $\mathrm{MgAl}$ keverékoxidhoz.

A hidrotalcit, melynek szerkezetébe rezet és krómot is vittünk, olyan szórásképet mutat, 
mely jól ötvözi a $\mathrm{Cu}$ - és $\mathrm{Cr}$-HT diffraktogramjait. A hökezelésen átesett minták esetén - a kezelés hömérsékletétől függetlenül - a $\mathrm{MgO}$ és $\mathrm{CuO}$ csúcsai a meghatározók, de utóbbiak intenzitása lényegesen kisebb, mint a Cu-HT-ban volt. Ebben az esetben is elmondható, hogy a használat során kismértékben visszaáll a réteges szerkezet, illetve az, hogy a regenerálás céljából történt hőkezelés nem elég hatékony ahhoz, hogy visszanyerjük a katalizátorok eredeti formáját.

Az új és regenerált minták kristálytani paramétereit a 8. táblázat foglalja össze. A regenerált, réztartalmú (Cu-, és $\mathrm{CuCr}-\mathrm{HT})$ mintákban a $\mathrm{MgO}$ reflexiói nem jelennek meg, ezért azt $\mathrm{x}$-szel jelöltem. A d-spacing kevés eltéréssel minden esetben, mind az új, mind a regenerált mintáknál, megfelelt az irodalomból ismert adatoknak, miszerint $\mathrm{MgO}: \mathrm{d}_{200}=2,10 \AA \mathrm{d}_{220}=$ $1,49 \AA$ [230]. A MgO részecskemérete a módosított mintákban - különösen a Cr-HT esetén nőtt a MgAl-hidrotalcitban lévőhöz képest, a regenerálás céljából izzított katalizátorok szemcsemérete viszont csökkenést mutatott a használatlan mintákkal összehasonlítva.

8. táblázat: Hidrotalcitok kristálytani paraméterei /d $(\AA), D(n m) /$ használat előtt és regenerálás után

\begin{tabular}{ccccccccccccc}
\hline \multirow{2}{*}{ MgO } & & \multicolumn{2}{c}{ MgAl } & \multicolumn{2}{c}{ Ni } & \multicolumn{2}{c}{ Cu } & \multicolumn{3}{c}{ Cr } & \multicolumn{3}{c}{ CuCr } \\
& & új & iz & új & iz & új & iz & új & iz & új & iz \\
\hline \multirow{2}{*}{$\mathbf{4 0 0}$} & $\mathbf{d}_{\mathbf{2 0 0}}$ & 2,09 & 2,09 & 2,10 & 2,10 & 2,10 & $\mathrm{x}$ & 2,10 & 2,09 & 2,10 & $\mathrm{x}$ \\
& $\mathbf{d}_{\mathbf{2 2 0}}$ & 1,48 & 1,48 & 1,48 & 1,48 & 1,49 & $\mathrm{x}$ & 1,49 & 1,48 & 1,48 & $\mathrm{x}$ \\
& $\mathbf{D}$ & 4,16 & 3,87 & 5,11 & 3,90 & 5,21 & $\mathrm{x}$ & 8,13 & 4,91 & 5,72 & $\mathrm{x}$ \\
& $\mathbf{d}_{\mathbf{2 0 0}}$ & 2,09 & 2,09 & 2,09 & 2,10 & 2,09 & $\mathrm{x}$ & 2,10 & 2,09 & 2,10 & $\mathrm{x}$ \\
$\mathbf{5 0 0}$ & $\mathbf{d}_{\mathbf{2 2 0}}$ & 1,48 & 1,48 & 1,48 & 1,48 & 1,48 & $\mathrm{x}$ & 1,49 & 1,47 & 1,48 & $\mathrm{x}$ \\
& $\mathbf{D}$ & 4,57 & 3,91 & 5,47 & 4,00 & 5,84 & $\mathrm{x}$ & 9,06 & 4,83 & 7,45 & $\mathrm{x}$ \\
& $\mathbf{d}$ & $\mathbf{d} 2 \mathbf{2 0 0}$ & 2,09 & 2,09 & 2,09 & 2,10 & 2,09 & $\mathrm{x}$ & 2,10 & 2,10 & 2,10 & $\mathrm{x}$ \\
$\mathbf{6 0 0}$ & $\mathbf{d}_{\mathbf{2 2 0}}$ & 1,48 & 1,48 & 1,48 & 1,48 & 1,48 & $\mathrm{x}$ & 1,49 & 1,48 & 1,48 & $\mathrm{x}$ \\
& $\mathbf{D}$ & 4,47 & 3,87 & 6,04 & 5,27 & 6,53 & $\mathrm{x}$ & 9,94 & 4,74 & 8,10 & $\mathrm{x}$ \\
\hline
\end{tabular}

A réztartalmú katalizátoroknál az izzított mintákból eltünt a MgO-ra jellemző reflexió, viszont élesen megjelenik a $\mathrm{CuO}$, melynek részecskeméretét valamint (-111) és (200) irányba mutató réteglap-távolságait a 9. táblázat tartalmazza.

$\mathrm{A} \mathrm{CuO}$ részecskemérete a regenerált mintákban szintén minden esetben csökkent az újéhoz képest. A réteglap-távolság nem változott és megfelel az irodalmi adatoknak: $\mathrm{d}_{-111}=2,52 \AA$; $\mathrm{d}_{200}=2,31-2,32 \AA[233]$. 
Kísérleti eredmények és értékelésük

9. táblázat: $\mathrm{A} \mathrm{CuO}$ szemcsemérete /D $(\mathrm{nm}) /$ és réteglaptávolsága /d $(\AA) /$ a réztartalmú keverékoxidoknál

\begin{tabular}{rlrrrr}
\hline \multirow{2}{*}{ CuO } & & \multicolumn{2}{c}{$\mathbf{C u}$} & \multicolumn{2}{c}{$\mathbf{C u C r}$} \\
& & \multicolumn{1}{c}{$\mathbf{j}$} & izzított & \multicolumn{1}{c}{ új } & izzított \\
\hline \multirow{3}{*}{ HT-400 } & $\mathbf{d}_{\mathbf{- 1 1 1}}$ & 2,52 & 2,53 & 2,52 & 2,52 \\
& $\mathbf{d}_{\mathbf{2 0 0}}$ & 2,32 & 2,32 & 2,32 & 2,32 \\
& $\mathbf{D}$ & 15,86 & 12,57 & 17,37 & 12,11 \\
& $\mathbf{d}_{-111}$ & 2,52 & 2,53 & 2,52 & 2,53 \\
HT-500 & $\mathbf{d}_{\mathbf{2 0 0}}$ & 2,32 & 2,32 & 2,32 & 2,32 \\
& $\mathbf{D}$ & 17,26 & 15,02 & 19,86 & 14,80 \\
& $\mathbf{d}_{-111}$ & 2,52 & 2,52 & 2,52 & 2,52 \\
HT-600 & $\mathbf{d}_{\mathbf{2 0 0}}$ & 2,32 & 2,32 & 2,32 & 2,32 \\
& $\mathbf{D}$ & 16,89 & 14,81 & 18,13 & 13,95 \\
\hline
\end{tabular}

A MgAl- és a NiMgAl-hidrotalcit tehát a regenerálás során nagymértékben visszanyeri eredeti formáját, míg a $\mathrm{Cu}$ - és Cr-tartalmú minták nem. Azaz az előbbi két anyag katalizátornak tekinthető, az utóbbi kettő pedig nem.

\subsection{Nitrogén-fiziszorpciós vizsgálatok eredményei}

\subsubsection{ZSM-5 zeolitok}

Az alkalmazott ZSM-5-katalizátorok fajlagos felületeit a 10. táblázat foglalja össze. A mért adatok megfelelnek a mások által közölt eredményeknek. A titánnal, illetve krómmal módosított minták felülete megközelítően azonos az H-formájú zeolitéval.

A szilárdfázisú ioncserével előállított $\mathrm{Cu}$ - és NiZSM-5-sz katalizátorok felülete az előbbieknél jóval kisebb, ami azzal magyarázható, hogy a $\mathrm{CuO}$, illetve $\mathrm{NiO}$ klaszterek részben elzárják a pórusokat.

10. táblázat: ZSM-5-katalizátorok fajlagos felülete $\left(\mathrm{m}^{2} / \mathrm{g}\right)$

\begin{tabular}{lcccccc}
\hline \multicolumn{1}{c}{ minta } & HZSM-5 & CuZSM-5 & Ti-ZSM-5 & CrZSM-5 & NiZSM-5-sz & NiZSM-5-f \\
\hline új & 285 & 218 & 278 & 281 & 222 & 253 \\
használt & 21 & 63 & 20 & 23 & 88 & 89 \\
regenerált & 248 & 186 & 247 & 244 & 198 & 223 \\
\hline
\end{tabular}

A használat során a fajlagos felület minden esetben jelentősen csökkent, melynek oka az, hogy a glicerin valószínűleg bepolimerizálódott a csatornákba kisebb-nagyobb hidrogéntartalmú szénréteg keletkezésével, amelyet sem vizes, sem metanolos mosással nem tudtuk onnan eltávolítani. Az irodalomban említett esetekben is szinte kivétel nélkül a kokszolódás problémájába ütköztek [64, 69], melynek megszüntetésére a leégetés a legelterjedtebb módszer. Ezért fontos, hogy a katalizátor nagy hőstabilitással rendelkezzék. 
A regenerálást én is hőkezeléssel valósítottam meg $600{ }^{\circ} \mathrm{C}$ hőmérsékleten, levegőáramban $\left(\mathrm{w}=15 \mathrm{dm}^{3} / \mathrm{h}\right), 4$ órán keresztül, melynek eredményeképp kicsit gyengébb aktivitással ugyan, de a katalizátort újabb kísérletekben is használni tudtam. A regenerálás során a pórusokban lerakódott szerves maradék oxidációja mellett a módosító réz oxidációs állapota is változott. A röntgenfelvételek alapján tudható, hogy a használat során $\mathrm{CuO}$-ból átalakult $\mathrm{Cu}_{2} \mathrm{O}$ a hökezelés hatására részben visszaalakul $\mathrm{Cu}(\mathrm{II})$-oxiddá.

A 41. ábra a használat előtti minták adszorpciós és deszorpciós izotermáit mutatja eredeti skálán $(A)$ ábrázolva, illetve az izoterma alakjának könnyebb értékelésének érdekében egymáshoz képest kicsit elcsúsztatva $(B)$.
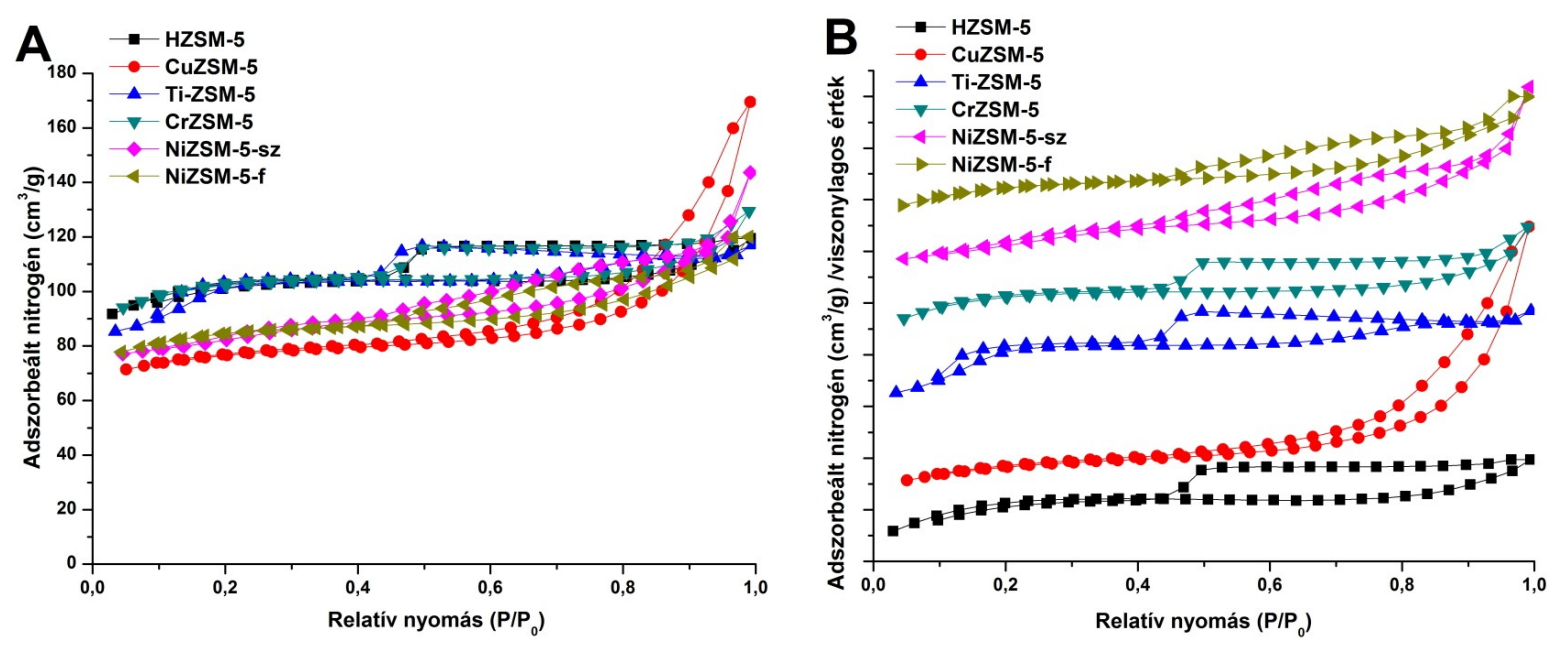

41. ábra: ZSM-5 zeolitok nitrogénadszorpciós izotermái eredeti skálán (A) és a skála elcsúsztatásával (B)

A Cr-, Ti- és HZSM-5 zeolitok izotermái a IUPAC osztályozás szerinti IV. kategóriába sorolhatók és H3 típusú hiszterézist mutatnak, vagyis az anyag mezopórusos, és az adszorpciódeszorpció a lapos részecskékből képződött aggregátumok közti résszerü pórusokban történik. A hiszterézis alakja, területe, pozíciója és $\mathrm{P} / \mathrm{P}_{0} \sim 0,4-0,45$ körül történő záródása alapján megállapítható, hogy a krómtartalmú és a módosítatlan ZSM-5 azonos pórusszerkezettel rendelkezik, míg a Ti-ZSM-5 csak kismértékben tér el ettől: itt enyhén kisebb pórusok vannak.

Mindhárom katalizátor esetében alacsony relatív nyomáson meredek a $\mathrm{N}_{2}$ adszoprciós ága, ami azt jelenti, hogy az izotermákban „rejtve” megjelenik az I. típusú izoterma is, azaz ezekben az anyagokban mikropórusok is vannak.

Ellenben a CuZSM-5-ben a IV. típusú izoterma és H1 hiszterézis alapján csak mezopórusok figyelhetők meg. A görbe sokáig szinte vízszintesen halad, amelyet $\mathrm{P} / \mathrm{P}_{0}=0,8$-nál követ egy meredek ugrás, majd miután a maximumot elérte az adszorpció, a deszorpciós ág szinte 
ugyanolyan meredeken csökken. A hiszterézishurok keskeny és $\mathrm{P} / \mathrm{P}_{0}=0,5$ körül záródik.

A nikkeltartalmú minták átmenetet képeznek a fentebb említett kétféle pórusosszerkezet között. A NiZSM-5-sz jobban mutatja a rézzel módosított zeolit tulajdonságait, míg a folyadékfázisú ioncserével előállított minta inkább az első részben leírt katalizátorokra hasonlít.

\subsubsection{Raney-nikkel}

A nitrogén-fiziszorpciós eredmények is megerősítették a röntgenfelvételek és az elemi összetétel vizsgálatakor felvetett elképzelést, miszerint a RNi-222A és RNi-222B közt szinte semmi különbség nincs. Mind az izoterma alakja, mind a BET felület majdnem azonos, meglehetősen alacsony. Ellenben a $320{ }^{\circ} \mathrm{C}$-on történt hökezelés (RNi-222C) jelentős felületnövekedést eredményezett, ami azzal magyarázható, hogy ezen a hőmérsékleten a gibbsit, a bayerit és a nordstrandit egy része böhmitté alakul, amelynek a szemcsemérete kisebb, következésképp a felülete nagyobb. Ez az előnyös tulajdonság azonban hiábavaló, hiszen a használat során szétváló mintákat regenerálni nem lehet.

Az egyes minták BET felületeit a 11. táblázat, adszorpciós izotermáit pedig a 42. ábra foglalja össze.

11. táblázat: Raney-nikkelek BET felülete a használat előtt és után $\left(\mathrm{m}^{2} / \mathrm{g}\right)$

\begin{tabular}{lcccc}
\hline \multicolumn{1}{c}{ minta } & RNi-212 & RNi-222A & RNi-222B & RNi-222C \\
\hline új & 12 & 28 & 28 & 73 \\
használt/fémes & & 5 & 7 & 10 \\
használt/maradék & 10 & 17 & 19 & 26 \\
\hline
\end{tabular}

Bár a RNi-212 fajlagos felülete jelentősen kisebb, mint az alumíniumtartalmú mintáké, a használat során az csak kismértékben csökkent.

A 222 sorozat használat során szétvált tagjainál megfigyelhető, hogy az - oxihidrátban gazdag - maradék felülete hozzávetőlegesen háromszor akkora, mint az intermetallikus (fémes) fázisé. A minden esetben megfigyelhető csökkenés részben a polimerizálódott anyagok, részben a nagyobb szemcseméretü gibbsit részarányának növekedésének tulajdonítható. A legnagyobb felületcsökkenés a 222C anyag esetében történt.

A 222 sorozat tagjainak izotermái a IUPAC osztályozás szerinti IV. típusba tartoznak. A H3 típusú hiszterézis hurok arra utal, hogy a minta lemezes részecskéket és résszerű pórusokat tartalmaz. A porózus szerkezethez mikropórusok jelenléte is hozzájárul, a 222A és 222B esetén nagyobb mértékben, míg a 222C minta szerkezetében a mezopórusok dominálnak. 


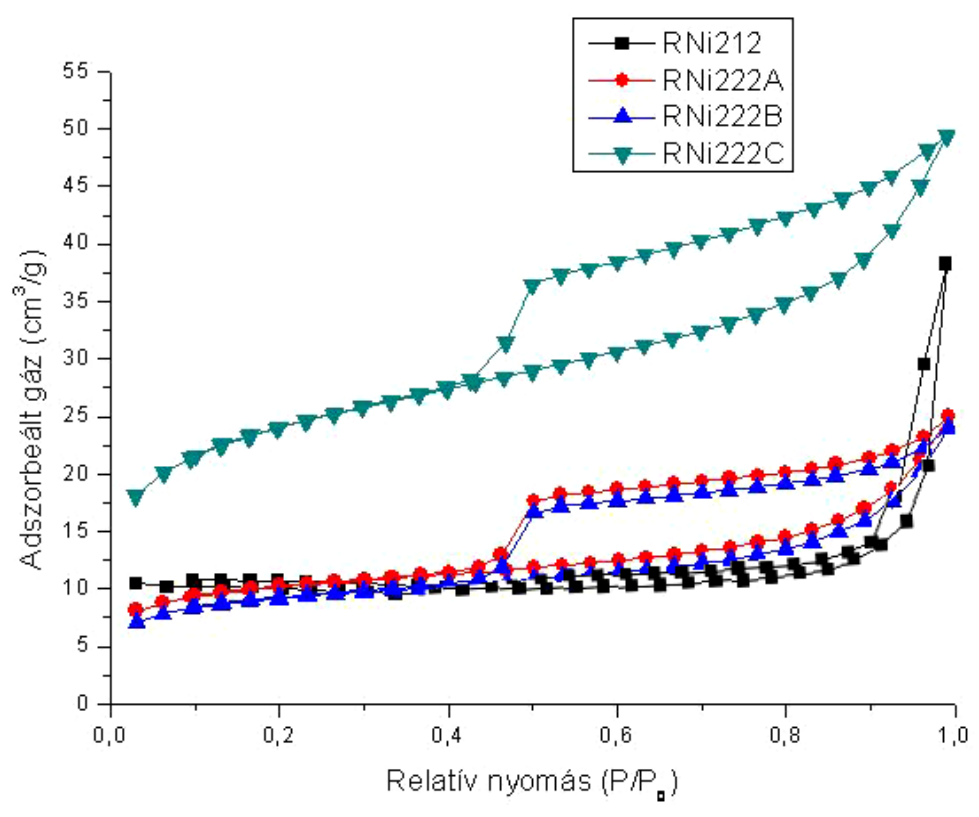

42. ábra: A használat előtti Raney-Ni-katalizátorok adszorpciós és deszorpciós izotermái

A RNi-212 alakja ezzel szemben jelentősen eltér a többitől, itt csak nagy $\mathrm{P} / \mathrm{P}_{0}$ értéknél következik be a telítés, ahol meredek ugrás tapasztalható. A minta kevésbé porózus, mint az alumíniumtartalmú katalizátorok. Feltehetően ennek köszönhető, hogy a lerakódó koksz kevésbé tudta károsítani a pórusrendszert (43. ábra), így felülete kevésbé csökken.

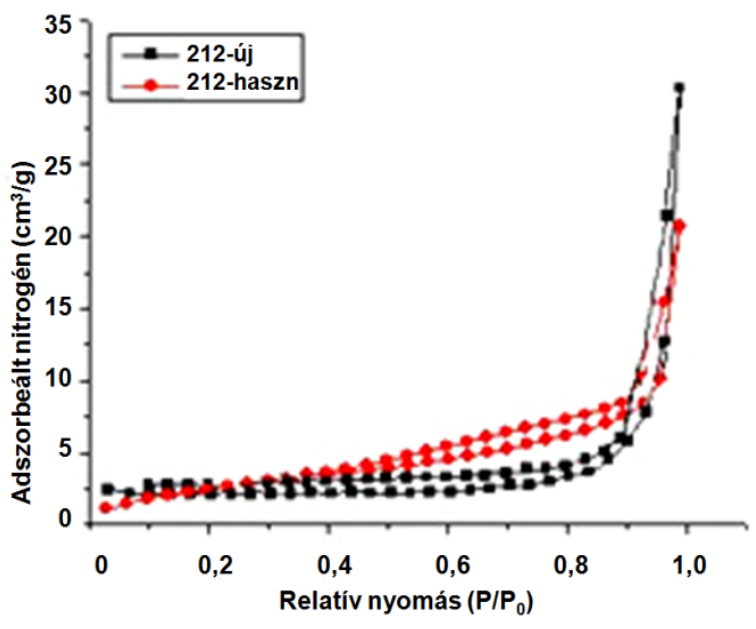

43. ábra: Új és használt RNi-212

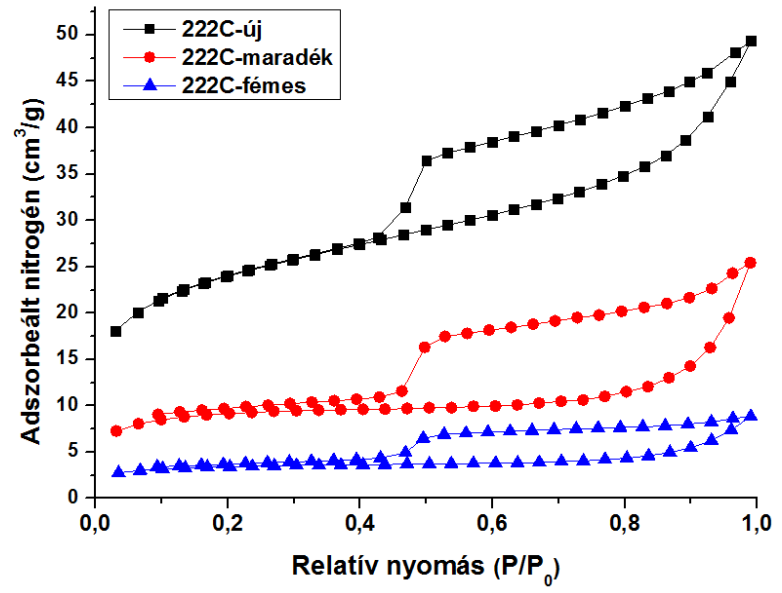

44. ábra: Új és használt RNi-222C

A használat során történt változásokat a RNi-222C példáján mutatja be a 44. ábra. A használatlan minta képéhez képest a maradék izotermája laposabb, a hiszterézis hurok szélesebb. A fémes AlNi adszorpciós képe szinte vízszintes és a hiszterézis is meglehetősen keskeny. 


\subsubsection{Hidrotalcitok}

A kiindulási LDH és a kalcinált anyag felületének nagysága között - Shumaker kutatócsoportjánál [191] tapasztaltakhoz hasonlóan - nem találtunk szoros összefüggést.

A hőkezeléssel a felület jelentősen növekedett, ami az eltávozó $\mathrm{CO}_{2}$ és a vízgőz eredményeképp bekövetkező kráterképződéssel valósult meg [234, 235]. A gázok eltávozása a termogravimetriás mérések (4.3.3. fejezet) alapján a $220-405{ }^{\circ} \mathrm{C}$ hőmérséklet-tartományban történt. A hőkezelésbeli különbség nem volt jelentős befolyással a felület nagyságára, bár az magasabb hőmérsékleten kismértékben csökkent.

Az is látható, hogy a különbözö fémek beépítése csökkentette a felületet. Ez összhangban áll azzal, hogy a szemcseméret a módosítással nőtt (8. táblázat), valamint hogy az együttes lecsapással előállított és $450{ }^{\circ} \mathrm{C}$-on hőkezelt $\mathrm{CuMgAl}$-hidrotalcitok esetén a $\mathrm{Cu}^{2+} / \mathrm{Mg}^{2+}$-arány növelésével Yuan és társai szintén a felület csökkenését tapasztalták [228].

A használat során több hatásnak is tulajdoníthatóan szintén jelentős mértékben csökkent a felület nagysága. Egyrészt a részben visszaalakult réteges szerkezet, másrészt a polimerizálódott kokszjellegü lerakódások is ezirányban hatottak.

A regeneráláskor alkalmazott hőkezelés következtében a keverékoxid szerkezete a módosítatlan és a Ni-LDH esetén nagymértékben helyreállt, ezért itt volt tapasztalható a legjelentősebb felületnövekedés is.

A hidrotalcitok fajlagos felületét a 12. táblázat foglalja össze.

12. táblázat A hidrotalcitok fajlagos felülete $\left(\mathrm{m}^{2} / \mathrm{g}\right)$

\begin{tabular}{lcccccccccc}
\hline & $\begin{array}{c}\text { as.-prep. } \\
\text { új }\end{array}$ & új & $\begin{array}{c}\mathbf{4 0 0} \\
\text { haszn. }\end{array}$ & iz. & új. & $\begin{array}{c}\mathbf{5 0 0} \\
\text { haszn. }\end{array}$ & iz. & új & $\begin{array}{c}\text { h00 } \\
\text { haszn. }\end{array}$ & iz. \\
\hline MgAl & 71 & 216 & 102 & 195 & 189 & 98 & 176 & 183 & 89 & 171 \\
$\mathbf{N i}$ & 50 & 188 & 65 & 158 & 179 & 82 & 155 & 167 & 77 & 148 \\
$\mathbf{C u}$ & 39 & 205 & 99 & 167 & 168 & 79 & 151 & 161 & 62 & 127 \\
$\mathbf{C r}$ & 48 & 168 & 70 & 139 & 150 & 70 & 139 & 144 & 72 & 125 \\
$\mathbf{C u C r}$ & 43 & 203 & 95 & 158 & 183 & 81 & 149 & 165 & 84 & 148 \\
\hline
\end{tabular}

A minták nitrogén-fiziszorpciós izotermái szintén a IV. típusba tartoznak (45. ábra). A H3 típusú hiszterézis és a mezopórusok magasabb relatív nyomáson megvalósuló telítése arra utal, hogy réses mezopórusok alakultak ki a lemezes rétegek aggregálódásával, illetve kráterképződéssel, ahol a kapilláris kondenzáció lassú. Hasonló izotermákat kapott Spiccia kutatócsoportja [236], valamint Tichit és munkatársai is [185]. 


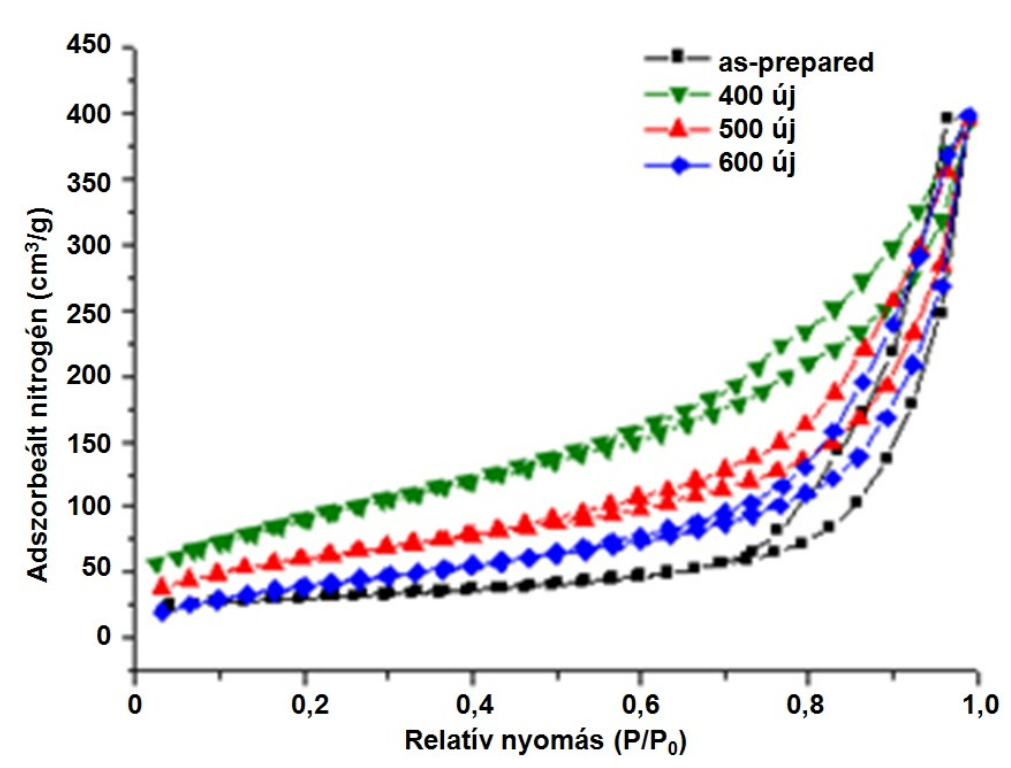

45. ábra: MgAl-hidrotalcit adszorpciós és deszorpciós izotermája

\subsection{Termikus stabilitás vizsgálatának eredményei}

\subsubsection{ZSM-5 zeolitok}

A Ti-ZSM-5 kivételével a többi minta kiindulási alapja a $600{ }^{\circ} \mathrm{C}-o n$ kalcinált NaZSM-5, vagy a szintén már hőkezeléssel előállított HZSM-5 volt, ezért a termogravimetriás mérések során számottevő tömegcsökkenésre nem kellett számítanunk. Ellenben a (kalcinálás elötti) TiZSM-5 esetén a templát kiégetésével a NaZSM-5 tömegvesztés és dTG görbéjéhez hasonló eredményt kaptunk. A tömegcsökkenés 2,6 \%, majd további 8,7 \% volt.

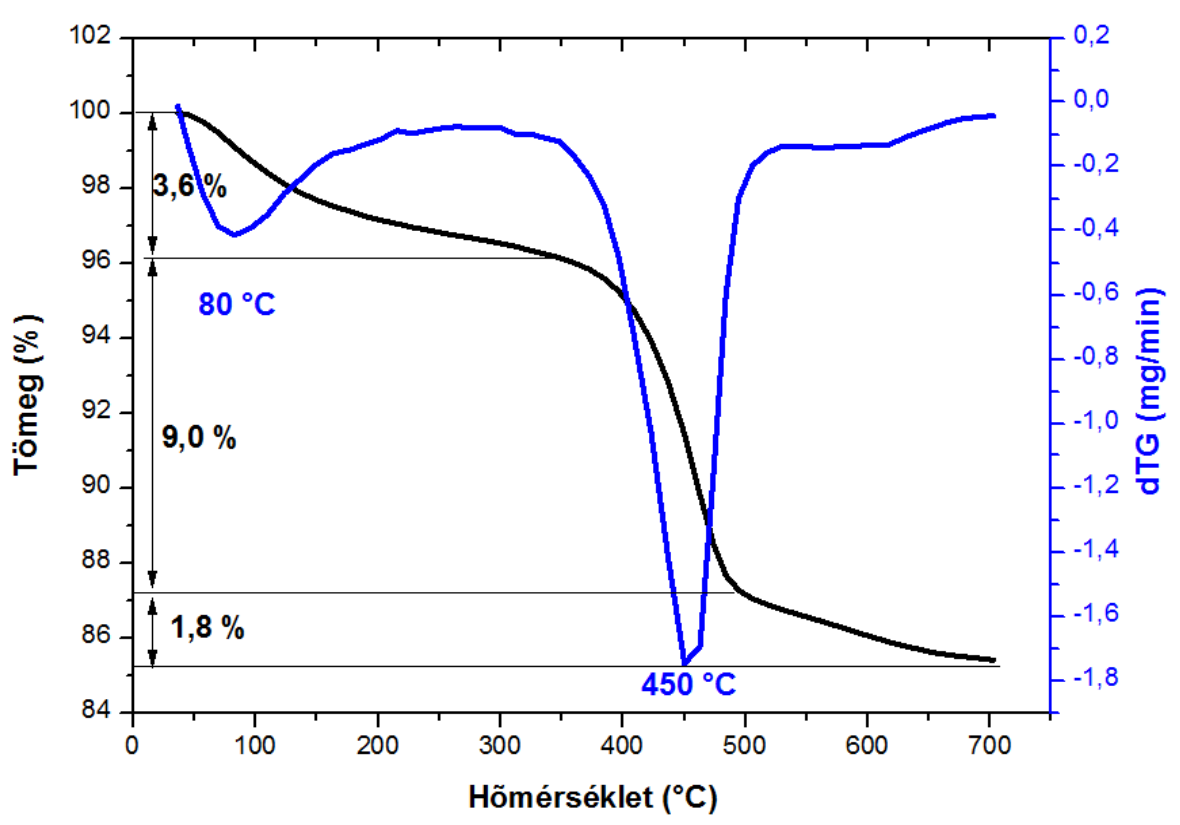

46. ábra: NaZSM-5 tömegvesztése és dTG görbéje 
A NaZSM-5 templát kiégetés előtti formájának termogravimetriás vizsgálati eredményeit a 46. ábra mutatja be. Az első kb. $25-360{ }^{\circ} \mathrm{C}$-os tartományban folyamatos, összesen 3,6 \% tömegvesztés tapasztalható a felületen és a csatornákban kötött víz eltávozásának következtében. Ezután a hőmérséklet emelésével további $9 \%$-ot vesztett a minta a tömegéből, ami a templát kiégésével magyarázható. Viszonylag erős a kölcsönhatás az anionos szervetlen zeolitváz és annak különböző részein jelenlévő kationos szerves képződmények között.

A dTG csúcs szerint a tömegvesztés maximális sebessége $450{ }^{\circ} \mathrm{C}$ környékén volt.

\subsubsection{Raney-nikkel}

A 47. ábra a RNi-222A minta tömegcsökkenését, hőáramát és dTG görbéjét ábrázolja.

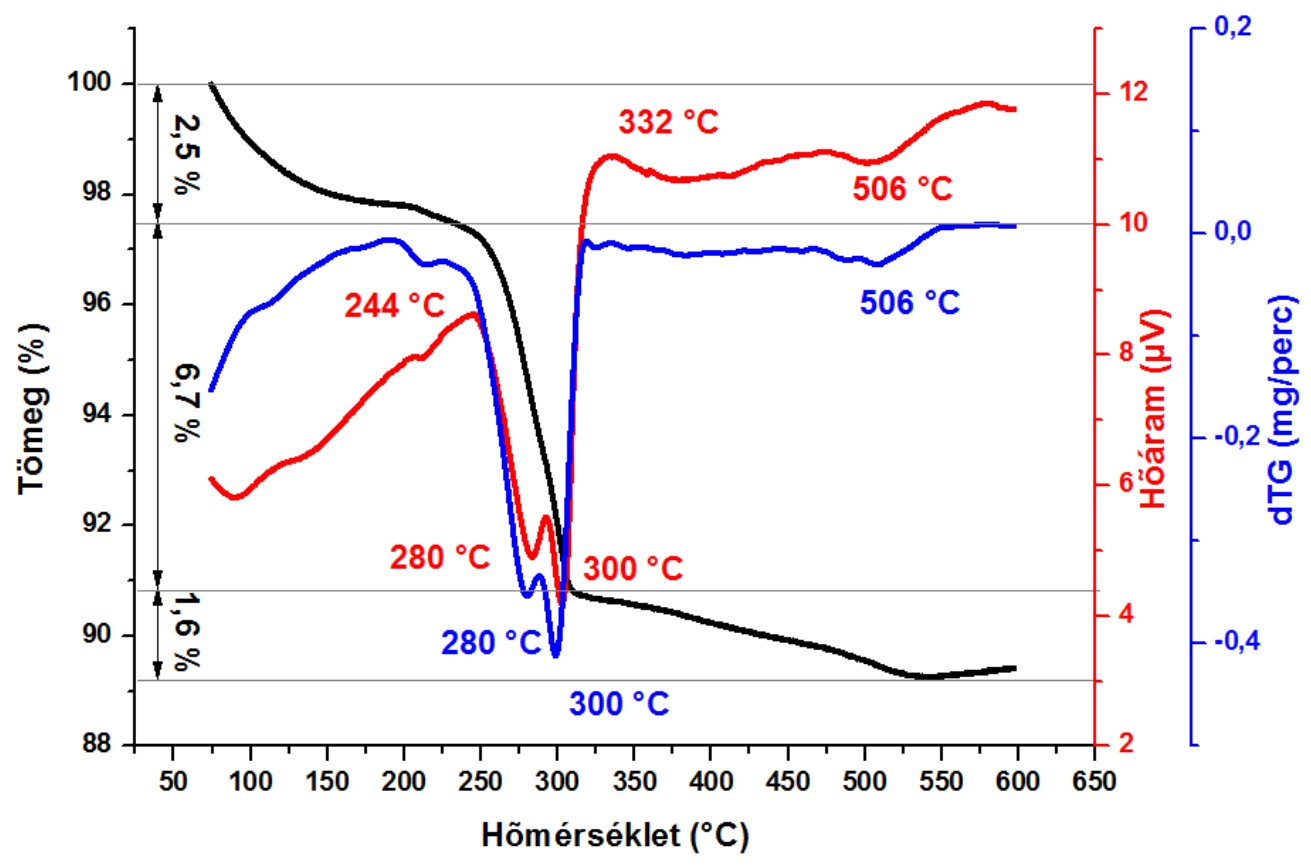

47. ábra: RNi-222A tömegvesztés-höáram-dTG görbéi

A tömegvesztést vizsgálva elmondhatjuk, hogy $244{ }^{\circ} \mathrm{C}$ eléréséig a minta a tömegének 2,5 \%-át vesztette el, ami feltehetően a felszínen lazán kötött víz eltávozásának köszönhető. A következő $\mathrm{kb}$. $60{ }^{\circ} \mathrm{C}$ hőmérséklet emelkedés hatására az összes tömegvesztés 9,2 \%-ra nő, ami a trihidrátok monohidráttá alakulásának tulajdonítható. Ez két lépésben történik meg, ahogy azt a dTG görbén a tömegvesztés maximális sebességét jelző két markáns csúcs mutatja 280, illetve $300{ }^{\circ} \mathrm{C}$ hömérsékleten. A hőmérséklet emelésével $528{ }^{\circ} \mathrm{C}$-ig még további $1,6 \%$ tömegvesztés történt, majd a mérés $600{ }^{\circ} \mathrm{C}$-on történő befejezéséig egyéb tömegváltozással járó esemény nem zajlott le.

A kapott eredmények megfelelnek az irodalomból ismert tapasztalatoknak, miszerint a 
bayerit-böhmit átalakulás $250{ }^{\circ} \mathrm{C}$ környékén [220] történik. A gibbsit-böhmit konverzióra vonatkozóan kapott mérési eredmények széles skálán helyezkednek el $205{ }^{\circ} \mathrm{C}$-tól [223] $277^{\circ} \mathrm{C}$-on át [224] $295-320^{\circ} \mathrm{C}$-ig [225, 226, 237]. Többen leírták azt is, hogy az alumíniumhidroxidok hőkezelésekor a böhmitből vagy gibbsitből 450 [227], illetve $520{ }^{\circ} \mathrm{C}$-on [226] további vízvesztéssel $\mathrm{Al}_{2} \mathrm{O}_{3}$ keletkezik.

A gibbsit (és bayerit) alumínium-oxiddá alakulása elméletileg 34,6 \% tömegvesztéssel jár [220, 225, 226] a következő egyenleteknek megfelelően:

\begin{tabular}{|c|c|c|c|c|c|}
\hline $\begin{array}{c}\gamma-\mathrm{Al}(\mathrm{OH})_{3} \\
\text { gibbsit }\end{array}$ & $\rightarrow$ & $\begin{array}{c}\gamma-\mathrm{AlOOH} \\
\text { böhmit }\end{array}$ & $\rightarrow$ & $\mathrm{H}_{2} \mathrm{O}$ & $-24-28 \%$ \\
\hline & $\rightarrow$ & $\begin{array}{c}0,5 \mathrm{Al}_{2} \mathrm{O}_{3} \\
\mathrm{Al} \text {-oxid }\end{array}$ & $\rightarrow$ & $0,5 \mathrm{H}_{2} \mathrm{O}$ & $-6-10 \%$ \\
\hline
\end{tabular}

Az egyes lépcsők százalékos tömegvesztései kísérleti adatok, nem pedig számolt értékek.

Ennél jóval kisebb tömegcsökkenést tapasztaltunk, de nem szabad elfelejtenünk, hogy a 222A és 222B esetén $45 \%$-ban, a RNi-222C tekintetében $59 \%$-ban AlNi-t tartalmaznak a minták, illetve azt, hogy az irodalomban említett tömegvesztés $700-950{ }^{\circ} \mathrm{C}$-on teljesedik ki, valamint, hogy a hordozó tartalmaz böhmitet is, melynek átalakulásakor már csak kevesebb víz távozik.

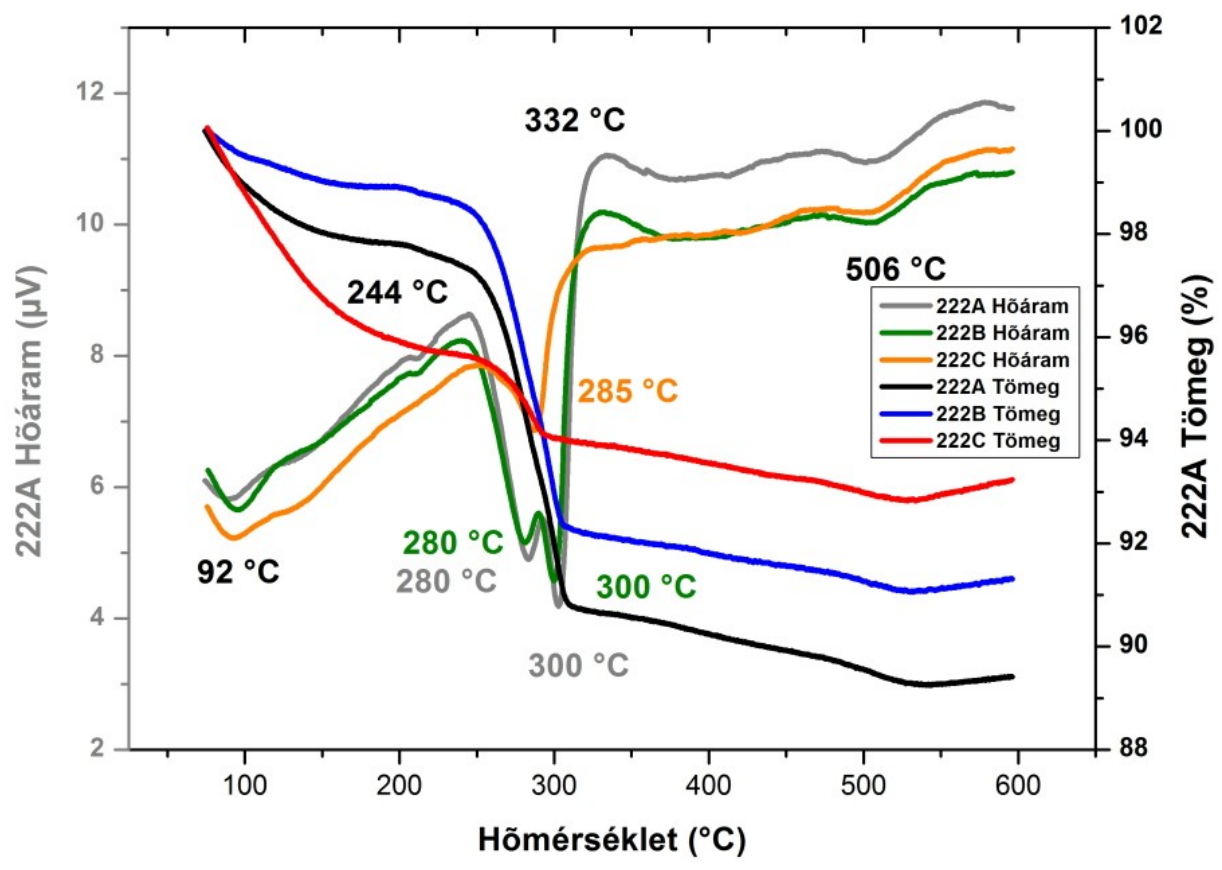

48. ábra RNi-222A, 222B és 222C tömegvesztése és hőárama

A RNi-222 sorozat tagjait a tömegvesztés, hőáram és dTG szempontjából a 48. ábra, 
illetve az 49. ábra hasonlítja össze. Megállapítható, hogy a dTG csúcs hozzávetőlegesen ugyanott helyezkedik el mindhárom minta esetén, de 222C-ben a víz erősebben kötött, hiszen az időegység alatt (percenként) eltávozó tömeg kevesebb, mint az a 222A és 222B esetén. A 222C minta tömegvesztést mutató görbéje viszonylag meredeken csökken, és a tömegének 4,4 \%-át elveszti az első kb. $250{ }^{\circ} \mathrm{C}$-on. Ezután még két kisebb lépcsőben további 1,5 + 1,3\% -ot veszít tömegéböl. Az összes tömegvesztés a vártnak megfelelően a 222A esetén volt a legnagyobb, azt követte sorrendben a 222B és 222C.

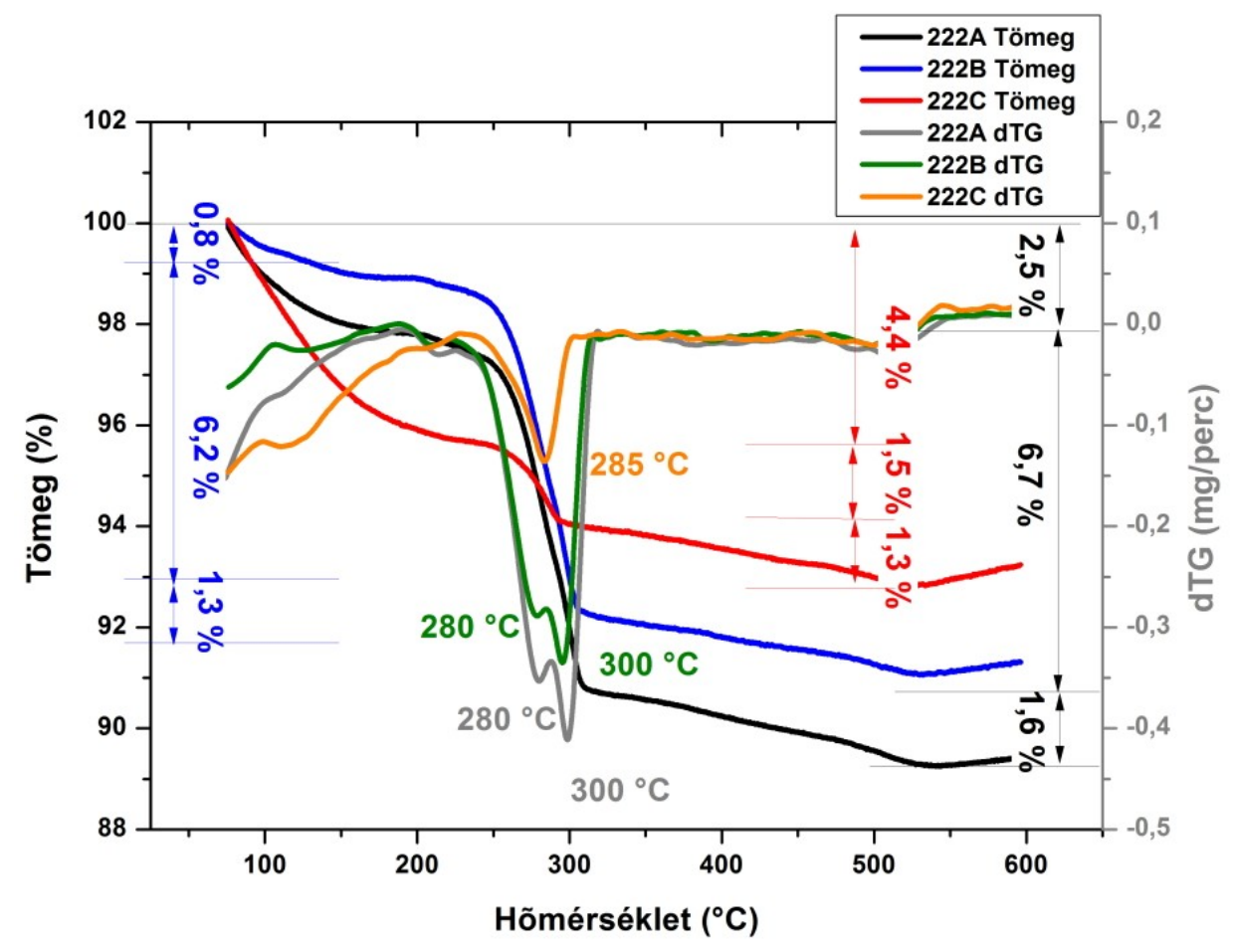

49. ábra: RNi-222A, 222B és 222C tömegvesztése és dTG görbéje

A RNi-212 esetén a vizsgált hőmérséklet-tartományban (szobahőmérséklet-600 ${ }^{\circ} \mathrm{C}$ ) nem történt jelentős tömegváltozás (egyedül a fiziszorbeálódott víz távozott el). Ez az eredmény jó egyezést mutat azzal, hogy a használatlan és a $600{ }^{\circ} \mathrm{C}$-on hőkezelt minták röntgendiffraktogramja azonosnak tekinthetők, és ez adta az ötletet, hogy a használt katalizátort hőkezeléssel regeneráljuk.

\subsubsection{Hidrotalcitok}

A MgAl-hidrotalcitok termikus tulajdonságainak tanulmányozásakor többen $[185,187$, 190, 228, 231, 238] kimutatták, hogy a tömegvesztés három lépésben zajlik. A gyengén kötött felszíni víz eltávozása már $100{ }^{\circ} \mathrm{C}$ alatt megkezdődik. Magasabb hőmérsékleten (220-250 ${ }^{\circ} \mathrm{C}$ ) a rétegközi térböl is eltávozik, melynek következtében csökken a rétegközi távolság [239]. Ezt követően $\left(330-450{ }^{\circ} \mathrm{C}\right)$ még további víz és a kitámasztó ionok bomlásából szárma- 
zó gázok - $\mathrm{CO}_{2}$ (karbonátok) vagy $\mathrm{NO}$ (nitrátok) - távoznak el. A fenti változások endoterm jellegüek, és általában összesen 35-46 \% tömegcsökkenéssel járnak [185].

Kísérleteimben a módosítatlan MgAl-hidrotalcit esetében az összes tömegvesztés 34,2 \%nak adódott. Az adszorbeálódott víz elvesztése 4,8\% csökkenést eredményezett $85{ }^{\circ} \mathrm{C}$-on. Ezután a rétegek közötti víz eltávozása 85 és $220^{\circ} \mathrm{C}$ között ment végbe, ami további $10,7 \%$ tömegveszteséget jelentett. A rétegek dehidroxileződése és dekarbonizálódása révén történő tömegvesztés maximumát a dTG görbén a $310{ }^{\circ} \mathrm{C}$-nál lévő csúcs jelzi. A tömegvesztés 405 ${ }^{\circ} \mathrm{C}$-on fejeződik be, és addig további 18,7 \%-kal csökken a minta tömege.

A különböző módosító fémek bevitele kismértékben csökkentette a stabilitást, a minták némiképp hamarabb bomlottak, mint a módosítatlan hidrotalcitok. Hasonló eredményt kaptak Frost és munkatársai is [240].

\subsection{Katalitikus tesztreakciók}

\subsubsection{Anyagmérleg}

A reaktív desztillációhoz $50 \mathrm{~cm}^{3} 87 \%$-os glicerint töltöttem a gömblombikba. Ennek tömegét lemértem és a reakció után összehasonlítottam a desztillátum és a desztillációs maradék tömegével. Kiszámoltam, hogy a kiindulási glicerin tömegének hány százalékát teszik ki a termékek, illetve a maradék, ezeknek összege pedig az anyagmérleget adta, ami minden esetben $98,2 \%-99,8 \%$ tartományba esett, ami jónak tekinthető.

\subsubsection{A különböző paraméterek változása a reaktív desztilláció közben}

A reaktív desztilláció kivitelezése során a hőmérsékletet egyenletesen emeltem fütőkosár segítségével, míg a csökkentett nyomást ( $\sim 25 \mathrm{kPa}$ ) vízsugárszivattyúval biztosítottam. Mind a desztillálandó folyadék (kezdetben tisztán a glicerin vizes oldata), mind az eltávozó gőz hőmérsékletének változását folyamatosan nyomon követtem. Az 50. ábra mutatja, hogy az első néhány percben a folyadék hőmérséklete gyorsan emelkedik, mialatt a gőz hőmérséklete szinte nem mutat változást. A 10-12. percben a glicerinoldat forrni kezd. Az ábrán itt meredek ugrás látszik a gőz hőmérsékletét jelző görbén, míg a folyadék hőmérsékletének emelkedése kismértékben visszaesik. A gőz hőmérséklete ezután $60^{\circ} \mathrm{C}$ körül szinte végig változatlan, míg a folyadékfázis esetén általában $240{ }^{\circ} \mathrm{C}$ környékén állandósul hozzávetőlegesen 120 perc után.

A nyomásprofilt a kezdeti hirtelen csökkenés utáni állandóság jellemezte. 
Kísérleti eredmények és értékelésük

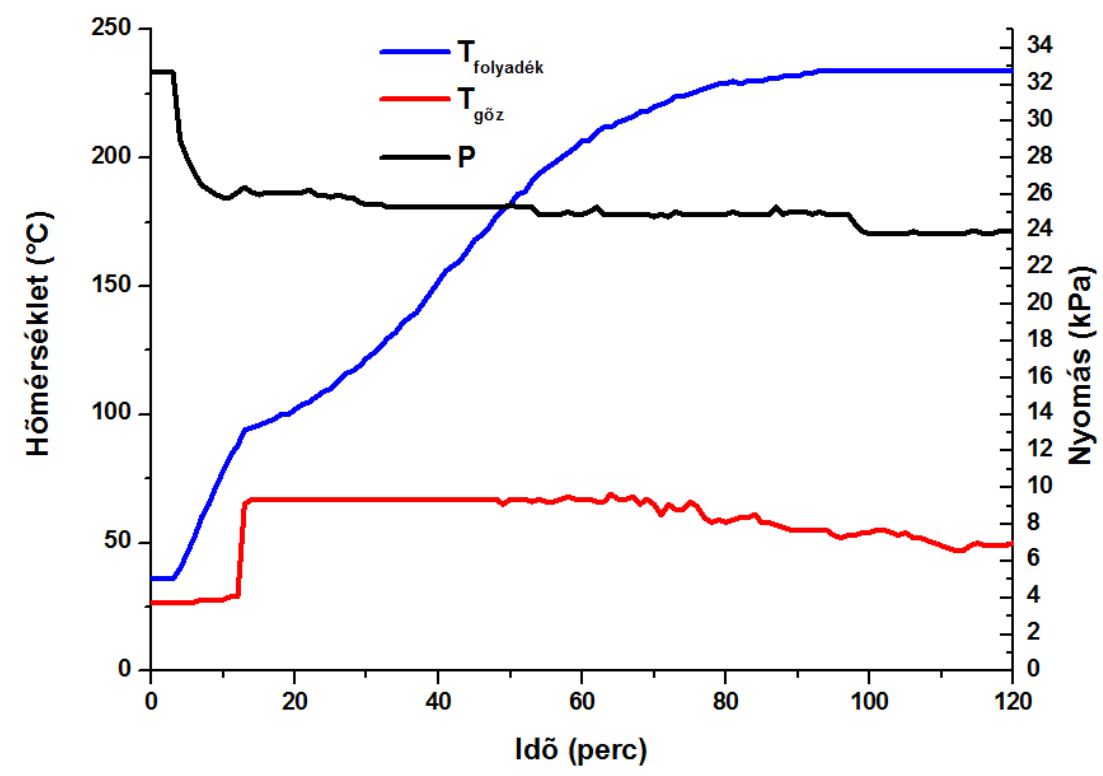

50. ábra: Hőmérséklet- és nyomásprofil
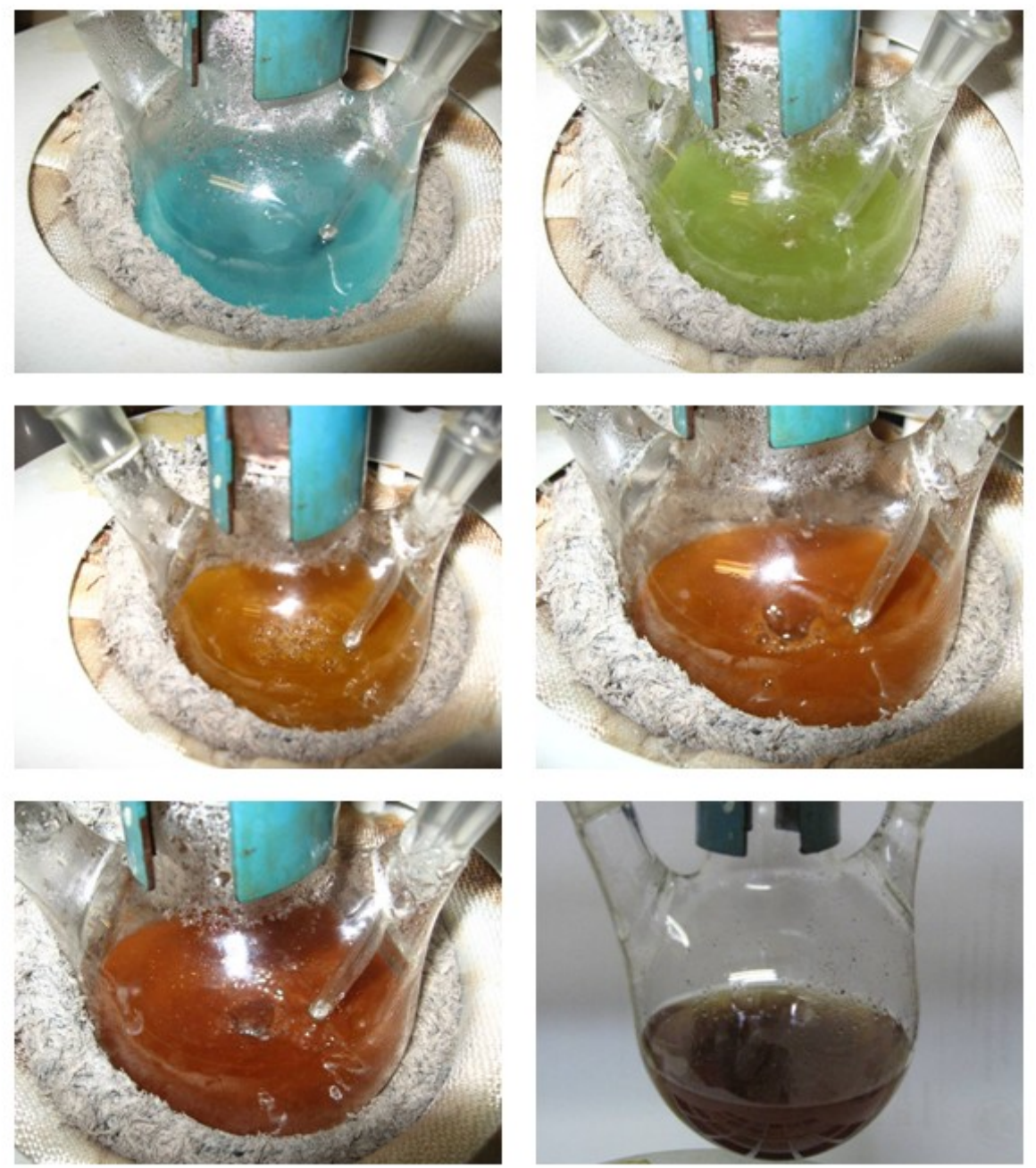

51. ábra: Színváltozás a CuMgAl keverékoxid használata során 
Látványos változás volt az, ahogy a reakcióidő elörehaladtával változik a reakcióelegy (51. ábra) és a katalizátor színe. A jelenség egyrészt a dehidratáció során kialakuló konjugált kettős kötések megjelenésével magyarázható. A glicerint tekinthetjük cukornak is, így a polimerizáció a karamell képződéséhez hasonló folyamat. Ha az oligomer cukrot dehidratáljuk, a színe egyre sötétebb lesz, és nő a viszkozitása, ez pedig gátolja a hőtranszfert. Ezért döntöttem úgy, hogy a reakcióidő 120 perc legyen. A színesedés másik oka, például a Cu-HT esetén, hogy a módosító réz oxidációs állapota megváltozott. Ahogy a $\mathrm{CuO}$ redukálódott a használat során $\mathrm{Cu}_{2} \mathrm{O}$-dá, a fekete katalizátorból rózsaszínes-mályvás színű anyag keletkezett

\subsubsection{Konverzió és szelektivitás}

Annak érdekében, hogy az egyes katalizátorok hatékonyságát jellemezhessem, meg kellett határoznom a glicerin konverzióját és a fő termék vagy az egyes termékek szelektivitását. Ma már úgy tartják, hogy utóbbi fontosabb tényező, mint a konverzió.

A termékanalízis megkezdése előtt felvettem a lehetséges keletkező termékek kromatogramjait. Egy adott anyag retenciós ideje eltérő lehet attól függően, hogy tisztán vagy más anyagokkal együtt fordul-e elő a vizsgált mintában. Ennek megfelelően az irodalomból ismert potenciális termékekből mesterségesen előállított elegyeket képeztem. Miután a tiszta anyagok kromatogramjait felvettem, az ismert összetételü elegy komponenseit azonosítani tudtam. A kromatogramokból a GC kiértékelő programjának segítségével meghatároztam a konverziót és a szelektivitást.

A desztillációs maradékot nagy viszkozitása miatt 2-propanollal hígítva vizsgáltam. Ez minden esetben szinte kizárólag glicerint, kondenzációs és polimerizációs termékeket tartalmazott.

A főbb termékek - a katalizátor jellegétől és a módosító iontól függő arányban - az acetol, az akrolein és az acetaldehid voltak. Ezen kívül előfordulnak még kis molekulatömegü degradációs termékek és ciklikus komponensek (például glicerinéterek), melyeket külön-külön nem azonosítottam.

\subsubsection{Katalizátor nélküli reakció}

Ha nem alkalmaztam katalizátort a fenti reakcióban, akkor az átalakulás mértéke ugyan nem elhanyagolható $(\sim 30 \%)$, de általában kisebb, mint a katalizált reakciókban, valamint a termékösszetétel sem kedvező. A főbb termékek az acetaldehid és az acetol, melyek kb. 1/3:1/3 arányban alkották a desztillátumot. A fennmaradó 1/3-ot az akrolein és egyéb, nem azonosított komponensek adták, melyek mennyisége külön-külön nem haladta meg az 3 \%-ot. 
Hogy az átalakulás hatékonyságát és az értékesebb termékekre (acetol) vonatkoztatott szelektivitást növeljem, különbözö, módosítatlan vagy módosított - alapvetően savas karakterü - ZSM-5 zeolitokat, bázikus jellegü hidrotalcitokból képzett keverékoxidokat és fémes Raney-nikkel-katalizátorokat alkalmaztam.

\subsubsection{ZSM-5 zeolitok}

ZSM-5 zeolitokkal legfeljebb közepes mértékủ átalakulást sikerült elérni. Az új és a regenerált minták használatával kapott konverziót és szelektivitást a 13. táblázat foglalja össze.

13. táblázat: A glicerin konverziója és a termékösszetétel ZSM-5-katalizátorok jelenlétében

\begin{tabular}{|c|c|c|c|c|c|c|c|c|c|c|c|c|}
\hline & \multicolumn{2}{|c|}{ HZSM-5 } & \multicolumn{2}{|c|}{ CuZSM-5 } & \multicolumn{2}{|c|}{ Ti-ZSM-5 } & \multicolumn{2}{|c|}{ CrZSM-5 } & \multicolumn{2}{|c|}{ NiZSM-5-sz } & \multicolumn{2}{|c|}{ NiZSM-5-f } \\
\hline & új & iz. & új & iz. & új & iz. & új & iz. & új & iz. & új & iz. \\
\hline konverzió & 24 & 19 & 14 & 10 & 16 & 9 & 30 & 20 & 55 & 48 & 54 & 46 \\
\hline $\mathbf{A A}$ & 7 & 10 & 14 & 20 & 47 & 50 & 7 & 14 & 83 & 85 & 78 & 80 \\
\hline AKR & 32 & 26 & 21 & 17 & 8 & 5 & 41 & 35 & 1 & 1 & 2 & 2 \\
\hline $\mathrm{ACE}$ & 30 & 23 & 58 & 45 & 37 & 25 & 10 & 8 & 8 & 3 & 13 & 8 \\
\hline egyéb & 31 & 41 & 7 & 18 & 8 & 20 & 42 & 43 & 8 & 11 & 7 & 10 \\
\hline
\end{tabular}

$\mathrm{AA}=$ acetaldehid, $\mathrm{AKR}=$ akrolein, $\mathrm{ACE}=$ acetol

A zeolit savas mivoltából és a keletkezett termékekböl arra lehet következtetni, hogy a reakció hasonló úton mehetett végbe, mint a Raney-nikkelek esetén, ahogyan azt a 4.4.3.3. fejezetben részletesebben ismertetem.

A különböző módosító ionok hatását vizsgálva megállapítható, hogy a NiZSM-5 müködése alapjaiban eltér a többi tesztelt mintáétól. A nikkel beépítése ugyan nagymértékben növelte a konverziót (54-55\%), azonban a degradációs folyamatok szerepe vált meghatározóvá. A fémbevitel módjától függetlenül 78-85 \% szelektivitással acetaldehid volt a fő alkotó. Ez azonban nem annyira preferált termék, mint az akrolein vagy az acetol lennének. Melléktermékként keletkezik minimális (1-2\%) akrolein, valamint 8-13\% acetol. Ezen kívül sok, kis $(<1 \%)$ azonosítatlan csúcs jelent meg a kromatogramon.

A Cr-ZSM-5 nem befolyásolta jelentősen a glicerin átalakulásának mértékét. A fő termék az akrolein (41\%), de jelentős arányban (7-10 \%) vannak jelen az acetol, a ciklikus komponensek és a különböző, kis molekulatömegű degradációs (például acetaldehid) termékek is.

A HZSM-5 használatával $24 \%$ konverzió volt megfigyelhető. Az acetol és az akrolein hozzávetőlegesen azonos arányban keletkezett ( $\sim 30-32 \%)$, míg a melléktermékeket az acetaldehid és ciklikus vegyületek tették ki. 
A CuZSM-5 használatával a $14 \%$ körüli konverzióhoz a többihez képest magas (58 \%) acetolszelektivitás párosul. Emellett az eddigiekhez hasonló arányban (14 \%, ill. $21 \%)$ keletkezik acetaldehid és akrolein. Az egyéb komponensek aránya elhanyagolható. Sato és munkatársai $\mathrm{Al}_{2} \mathrm{O}_{3}$ hordozóra vitt $\mathrm{Cu}$-katalizátoron a $\mathrm{Cu}$ és a sav együttes hatásának köszönhetően tapasztaltak nagyarányú acetolképződést glicerin dehidratációjában [67].

A Ti-ZSM-5 aktivitása (16\% konverzió) némileg nagyobb, mint a CuZSM-5 esetén tapasztalt, de a termékösszetétel kedvezőtlenebb. Az acetaldehid a fötermék (47\%), és emellett csak az acetol (37\%) és az akrolein ( $8 \%$ ) jelenléte haladja meg a $3 \%$-os arányt.

A fentiek alapján arra a megállapításra jutottunk, hogy a ZSM-5 zeolitok nem mutatkoztak kiemelkedően hatékony katalizátornak glicerin reaktív desztillációjában. A konverzió alacsonyabb (Cu-, Ti-ZSM-5) vagy hasonló (H-, CrZSM-5) volt, mint katalizátor jelenléte nélkül, és csak a Ni-tartalmú minták növelték az átalakulást.

A főtermék aránya általában nem sokkal haladta meg a melléktermékekét. Ez alól kivétel a NiZSM-5 a figyelemre méltó, 80 \% feletti szelektivitásával, viszont az itt keletkező acetaldehid a potenciális termékek közül a legkevésbé értékes. Bár a CuZSM-5 50 \% feletti arányban segítette elő az acetol képződését, a glicerin konverziója ebben az esetben csak 14 \%.

A hőkezeléssel történt regenerálás után újrahasználva a mintákat általánosságban elmondható, hogy aktivitásuk némiképp csökkent, és a termékképződés kicsit a degradációs irányba mozdult el.

\subsubsection{Raney-nikkel}

Az új típusú Raney-nikkelek lényegesen nagyobb aktivitást mutattak, és a szelektivitásuk is kedvezőbb volt, mint a ZSM-5-katalizátoroké. Az acetol volt a fötermék minden esetben, melynek arányát egyetlen más termék sem közelítette meg. A reakció feltehetően az 52. ábraán ismertetett módon zajlik le.

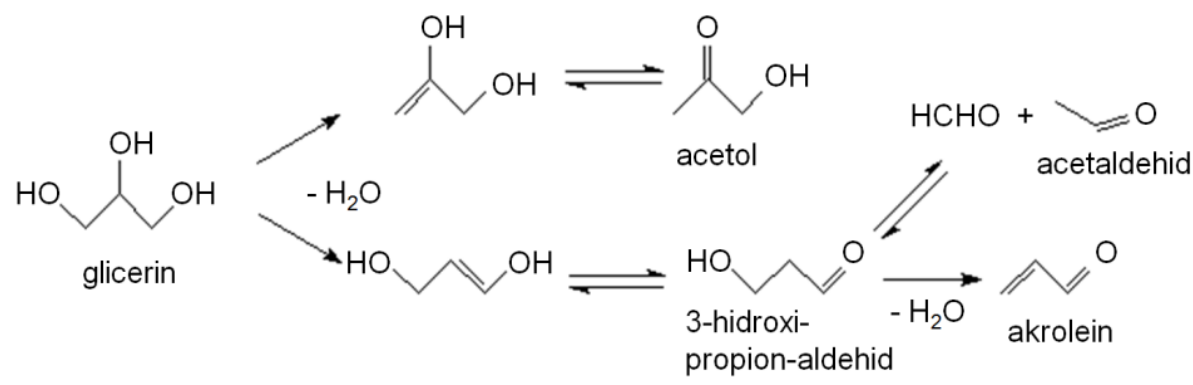

52. ábra: Glicerin átalakulásának feltételezett reakcióútja RNi-katalizátorok jelenlétében

A 14. táblázatban foglaltam össze a konverzió- és szelektivitás-eredményeket. 
Kísérleti eredmények és értékelésük

14. táblázat: Konverzió és szelektivitás Raney-nikkel-katalizátorok jelenlétében (\%)

\begin{tabular}{lcccc}
\hline RNi & RNi-222A & RNi-222B & RNi-222C & RNi-212 \\
\hline konverzió & 72 & 75 & 49 & 82 \\
AA & 2 & 2 & 0 & 3 \\
AKR & 6 & 2 & 10 & 8 \\
ACE & 74 & 72 & 87 & 70 \\
egyéb & 18 & 24 & 3 & 19 \\
\hline
\end{tabular}

$\mathrm{AA}=$ acetaldehid, $\mathrm{AKR}=$ akrolein, $\mathrm{ACE}=$ acetol

Az RNi-212 esetén a $80 \%$ feletti konverzióhoz $70 \%$ acetolszelektivitás párosult.

Hasonlóan ígéretes mintának mutatkozott a RNi-222A és RNi-222B is, kisebb konverzióval (72-75\%), de kissé magasabb acetolszelektivitással (72-74\%). Utóbbiak nemcsak szerkezetükben, de müködésükben is szinte azonosak. Ezzel szemben a RNi-222C jelenlétében bár az acetolszelektivitásában (87 \%) növekedés volt megfigyelhető, a konverzió nagyban elmarad (49\%) a többi minta esetén tapasztaltakhoz képest. A RNi-222C használatával a desztillátum 97 \%-át az acetol és az akrolein teszik ki. Ez az arány a többi esetben is $74-80 \%$ felett van. A degradációs termékek aránya elenyésző.

Mivel a RNi-222A, -B és -C a 4.1.2. fejezetben leírt módon szétváltak, regenerálásról nem beszélhetünk, így a klasszikus értelemben véve nem tekinthetők katalizátoroknak sem.

A RNi-212 azonban nemcsak az első használat alkalmával eredményezett nagy konverziót és acetolszelektivitást. A használt katalizátorokat $600{ }^{\circ} \mathrm{C}$ hőmérsékleten izzítva regeneráltam. Azért választottam ezt a hőmérséletet, mert a TG- és röntgenfelvételek szerint itt még nem történik szerkezeti változás, azonban a hőmérséklet már elég magas ahhoz, hogy a szerves maradékok nagy valószínüséggel eltünjenek. A regenerált RNi-212-katalizátort újabb reakciókban teszteltem. A második használatkor a konverzió ugyan kismértékben csökkent (RNi212-iz(1)) az első reakcióéhoz képest, de amint azt korábban láthattuk, a BET felület is csökkent az első használattal. Figyelemreméltó eredmény azonban, hogy a további három reakció során ((RNi-212-iz(2), (RNi-212-iz(3), (RNi-212-iz(4)) a konverzió és a termékszelektivitás is közel változatlan maradt (15. táblázat). 
Kísérleti eredmények és értékelésük

15. táblázat: Konverzió és szelektivitás az új és a regenerált Raney-nikkel-katalizátorok jelenlétében (\%)

\begin{tabular}{lccccc}
\hline RNi & RNi-212 & RNi-212-iz(1) & RNi-212-iz(2) & RNi-212-iz(3) & RNi-212-iz(4) \\
\hline konverzió & 82 & 75 & 75 & 74 & 75 \\
AA & 3 & 6 & 4 & 3 & 6 \\
AKR & 8 & 10 & 8 & 8 & 9 \\
ACE & 70 & 66 & 70 & 70 & 67 \\
egyéb & 19 & 18 & 18 & 19 & 18 \\
\hline
\end{tabular}

$\mathrm{AA}=$ acetaldehid, $\mathrm{AKR}=$ akrolein, $\mathrm{ACE}=$ acetol

A RNi-212 az aktivitás, a szelektivitás és a regenerálhatóság követelményeinek is eleget tesz, ezzel ígéretes katalizátornak tünik.

\subsubsection{Hökezelt réteges kettös hidroxidok}

A hőkezelt LDH-k használatával sikerült a konverziót 46-95 \%-ra növelni, és eltolni a termékképződést az acetol irányába. A fötermék tehát az acetol, és a legnagyobb arányban jelenlévő melléktermék az akrolein volt. A glicerin átalakulásának feltételezett reakcióútját az 53. ábra foglalja össze.

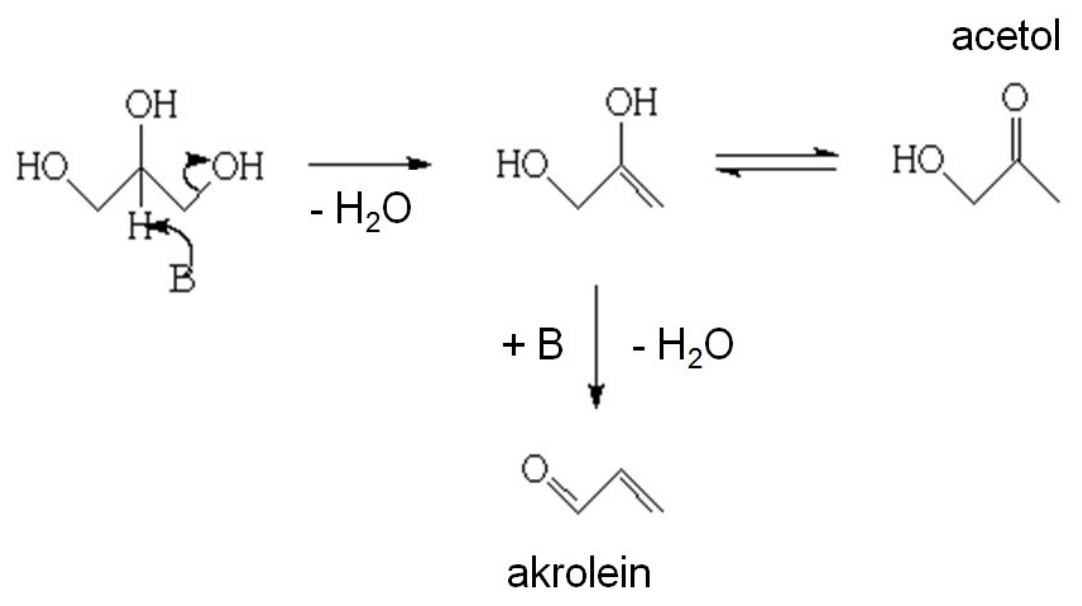

53. ábra: Glicerin feltételezett átalakulása hőkezelt kettős hidroxidok jelenlétében

A katalizátorok előkezelésének hőmérséklete nem volt jelentős befolyással sem az aktivitásra, sem a szelektivitásra, ahogyan ezt a 16. táblázatban összefoglalt konverzió- és szelektivitáseredmények mutatják.

A hőkezelt MgAl-, valamint a Ni- és Cr-ot tartalmazó LDH-k használata esetén közepes konverzió mellett a desztillátum szinte teljes mennyiségét az acetol (79-82\%), az akrolein (14-16\%), az allilalkohol (1-2\%) és az acetaldehid (1-2\%) adták. 
A hőkezelt réztartalmú LDH használata $92 \%$ feletti glicerinkonverziót, ám acetolra nézve csekélyebb (66-75\%) szelektivitást biztosított. Az akrolein (10-12\%) aránya kismértékben csökkent, ellenben az acetaldehid (2-4\%), és allilalkohol (5-6\%) szelektivitása nőtt. Csak itt fordult elő etilénglikol (2-4\%) a termékek között.

A kétfémes hőkezelt CuCr-LDH ötvözi a réz által elősegített magas konverzió, és a króm okozta magas acetolszelektivitás előnyeit: A konverzió szinte azonos a csak rezet tartalmazó hőkezelt LDH alkalmazása esetén tapasztaltakkal ( $94 \%)$, míg a króm beépítésével az acetolszelektivitását sikerült 67 \%-ról 74 \%-ra növelni.

Mindezek alapján a CuCr-LDH-ból hőkezeléssel készített keverékoxid lehet érdemes további vizsgálatokra. Azt azonban meg kell jegyeznem, hogy ez az anyag bár egyszer hatékonyan segítette elő a glicerin átalakítását, nem sikerült regenerálnom, így a klasszikus értelemben véve nem tekinthető katalizátornak.

16. táblázat: Glicerinkonverzió és termékösszetétel a keverékoxidok használatával

\begin{tabular}{lcccccccc}
\hline & T/ & Konv & AA & AKR & ALA & ACE & EG & egyéb \\
\hline MgAl & 400 & 50 & 1 & 14 & 1 & 82 & 0 & 2 \\
MgAl & 500 & 53 & 1 & 15 & 1 & 81 & 0 & 2 \\
MgAl & 600 & 49 & 1 & 14 & 1 & 82 & 0 & 2 \\
\hline $\mathbf{C u}$ & 400 & 95 & 3 & 12 & 5 & 67 & 2 & 11 \\
$\mathbf{C u}$ & 500 & 95 & 3 & 11 & 6 & 66 & 4 & 10 \\
$\mathbf{C u}$ & 600 & 92 & 2 & 11 & 5 & 68 & 3 & 11 \\
\hline $\mathbf{C u C r}$ & 400 & 95 & 3 & 11 & 5 & 75 & 2 & 4 \\
$\mathbf{C u C r}$ & 500 & 94 & 4 & 12 & 5 & 74 & 3 & 2 \\
$\mathbf{C u C r}$ & 600 & 93 & 3 & 10 & 5 & 73 & 3 & 6 \\
\hline $\mathbf{C r}$ & 400 & 47 & 1 & 15 & 1 & 81 & 0 & 2 \\
$\mathbf{C r}$ & 500 & 46 & 1 & 15 & 2 & 79 & 0 & 3 \\
$\mathbf{C r}$ & 600 & 49 & 1 & 16 & 1 & 79 & 0 & 3 \\
\hline $\mathbf{N i}$ & 400 & 53 & 1 & 14 & 1 & 81 & 0 & 3 \\
$\mathbf{N i}$ & 500 & 54 & 2 & 14 & 1 & 82 & 0 & 1 \\
$\mathbf{N i}$ & 600 & 53 & 2 & 14 & 1 & 80 & 0 & 3 \\
\hline
\end{tabular}

konv= konverzió; $\mathrm{AA}=$ acetaldehid, $\mathrm{AKR}=$ akrolein, $\mathrm{ALA}=$ allilalkohol, $\mathrm{ACE}=$ acetol, $\mathrm{EG}=$ etilénglikol

A hőkezelt MgAl-LDH és NiMgAl-LDH bár némiképp kisebb (50\%) konverzióval, de hatékonyan vesznek részt a glicerin értékesebb termékekké (acetol > 80 \%) való átalakításában. Használatukkor a réteges szerkezet teljes mértékben helyreállt a glicerin átalakulásakor kilépő víznek köszönhetően. A mintákat az előkezelés hőmérsékletén újrakalcinálva azonban a használatlan minták fajlagos felületéhez (4.2.3. fejezet) hasonló, és szerkezetével szinte 
azonos szerkezetủ keverékoxidokat kaptam (4.1.3. fejezet), vagyis sikeresen regeneráltam.

Ezeket az újrakalcinált (regenerált) mintákat újabb kísérletben használva azt tapasztaltam, hogy hasonló, kismértékben alacsonyabb konverzió mellett a termékeloszlás csak kismértékben változott az első használattal összehasonlítva (17. táblázat).

17. táblázat: Glicerinkonverzió és termékösszetétel a regenerált keverékoxidok használatával

\begin{tabular}{|c|c|c|c|c|c|c|c|c|}
\hline & $\mathbf{T} /{ }^{\circ} \mathbf{C}$ & konv & $\mathbf{A A}$ & AKR & ALA & ACE & EG & egyéb \\
\hline MgAl & 400 & 47 & 2 & 13 & 2 & 77 & 0 & 6 \\
\hline MgAl & 500 & 45 & 3 & 14 & 2 & 75 & 0 & 6 \\
\hline MgAl & 600 & 45 & 2 & 13 & 2 & 75 & 0 & 8 \\
\hline $\mathbf{N i}$ & 400 & 49 & 2 & 13 & 2 & 76 & 0 & 7 \\
\hline $\mathbf{N i}$ & 500 & 50 & 2 & 13 & 2 & 76 & 0 & 7 \\
\hline $\mathbf{N i}$ & 600 & 50 & 2 & 12 & 2 & 75 & 0 & 9 \\
\hline
\end{tabular}

konv= konverzió; $\mathrm{AA}=$ acetaldehid, $\mathrm{AKR}=$ akrolein, $\mathrm{ALA}=$ allilalkohol, $\mathrm{ACE}=$ acetol, $\mathrm{EG}=$ etilénglikol

Mivel regenerálás után a MgAl-LDH és NiMgAl-LDH sikeresen újrahasználhatók, ezeket a mintákat valóban katalizátornak tekinthetjük. 


\section{5. Összefoglalás}

Az Európai Unió kitüzött céljai között szerepel a bio-motorhajtóanyagok arányának növelése. A biodízel nagyléptékü gyártása napjainkra megvalósult, ám a folyamat során nagy mennyiségü glicerin keletkezik melléktermékként, melyet mind gazdasági, mind környezeti szempontból hasznosítani muszáj és érdemes is. A glicerin alkalmazható ugyan az iparban, de a várható túltermelés szükségessé teszi egyéb hasznosítási lehetőségek felkutatását és kiaknázását.

Feladatul tüztem ki, hogy megfelelő módszert, katalizátort és körülményeket találjak ahhoz, hogy a felesleges glicerint értékes termékekké alakítsam. A sokféle lehetséges reakció közül a dehidratációt választottam a kutatás témájának, melyet reaktív desztillációs technikával valósítottam meg. A módszer előnye a hagyományos eljárással (reakció+desztilláció) szemben, hogy a keletkező termékek folyamatos elválasztásával megakadályozhatjuk azok továbbalakulását, ezzel is növelve a szelektivitást. A cél a mellékreakciók elkerülésével a dehidratáció fötermékeit, - az acetolt és/vagy akroleint - minél nagyobb arányban kinyerni, melyek maguk is fontos vegyipari alapanyagok, illetve egy következő lépésben továbbhidrogénezve még értékesebb propándiolokká alakíthatók.

Az alkalmazott potenciális katalizátorok között voltak savas karakterü ZSM-5 zeolitok, bázikus hidrotalcitokból hőkezeléssel előállított keverékoxidok, és az új típusú, nem piroforos Raney-nikkel-katalizátorok.

Az alapként használt NaZSM-5 $(\mathrm{Si} / \mathrm{Al}=13,8)$ zeolitból, a templát kiégetése után egyrészt folyadékfázisú ioncserével kialakítottam a Cr- és NiZSM-5-f mintákat, másrészt $\mathrm{NH}_{4}{ }^{+}$-ioncserét követően az $\mathrm{NH}_{3}$-eltávozásával megkaptam a HZSM-5-öt, melyből szilárdfázisú ioncserével állítottam elő a Cu- és NiZSM-5-sz mintákatkat. A Ti-tartalmú zeolit szintézise izomorf szubsztitúcióval történt.

A hidrotalcitokat $(\mathrm{Mg} / \mathrm{Al}=2)$ az $\mathrm{Al}\left(\mathrm{NO}_{3}\right)_{3} \cdot 9 \mathrm{H}_{2} \mathrm{O}+\mathrm{Mg}\left(\mathrm{NO}_{3}\right)_{2} \cdot 6 \mathrm{H}_{2} \mathrm{O}$ és $\mathrm{Na}_{2} \mathrm{CO}_{3}+\mathrm{NaOH}$ vizes oldatainak lúgos körülmények közötti összecsepegtetésével, folyamatos keverés és hütés mellett, az úgynevezett együttes lecsapás módszerével állítottam elő. A módosító fémionokat $\left(\mathrm{Ni}^{2+}, \mathrm{Cu}^{2+}, \mathrm{Cr}^{3+}\right)$ az $\mathrm{Al}^{3+}$ illetve $\mathrm{Mg}^{2+} 10$ mólszázalékának helyettesítésével vittem a szerkezetbe. A mosott, szürt, szárított mintákból hőkezeléssel $\left(400{ }^{\circ} \mathrm{C}, 500{ }^{\circ} \mathrm{C}, 600{ }^{\circ} \mathrm{C}\right)$ alakítottam ki a keverékoxidokat.

Az új típusú Raney-Ni mintákat készen kaptuk tesztelésre. Előállításukkor 1:1 tömegarányú Ni-Al ötvözetporból két lépésben, a szokásosnál enyhébb körülmények között kioldották az alumínium egy részét, ezáltal trihidrátok $\left(\mathrm{Al}(\mathrm{OH})_{3}\right)$ : bayerit, gibbsit és nordstrandit váltak 
ki, melyek a kialakult intermetallikus alumínium-nikkel ( $\mathrm{AlNi}, \mathrm{Al}_{3} \mathrm{Ni}_{2}$ ), „hordozói”. A nikkel diszpergáltságának növelésével a piroforosságot sikerült kiküszöbölni. A mintákat $50{ }^{\circ} \mathrm{C}$-on szárították (222A) és egyes esetekben hökezelték (222B: $120{ }^{\circ} \mathrm{C}$; $222 \mathrm{C}$ : $320{ }^{\circ} \mathrm{C}$ ), melynek során a trihidrátok egy része vízvesztéssel részben átalakult böhmitté $(\mathrm{AlO}(\mathrm{OH}))$. Egy mintában az Al-ot Si-mal helyettesítették (RNi-212), ez szilíciumba ágyazott Ni-szilicidnek tekinthető, amely szintén $50{ }^{\circ} \mathrm{C}$ lett szárítva, majd $320^{\circ} \mathrm{C}$-on kalcinálva.

A használat előtt, után és a regenerálást követően, illetve a szintézis közben (hőkezelés elötti, ,as-prepared” hidrotalcitok) röntgendiffraktometriával, nitrogén adszorpciós és termogravimetriás mérésekkel vizsgáltam a katalizátorok szerkezetét, felületét, termikus viselkedését és az esetlegesen bekövetkező változásokat.

Az alkalmazott zeolitok röntgendiffrakciós szórásképe jól mutatta a ZSM-5-re jellemző reflexiókat. Az izomorf szubsztitúció (Ti) és a folyadékfázisú ioncsere $(\mathrm{Cr}, \mathrm{Ni})$ nem okozott számottevő változást a szerkezetben. Ezzel szemben a szilárdfázisú ioncserével létrehozott CuZSM-5 és NiZSM-5-sz esetén némileg csökkent az intenzitás, és új reflexiók (CuO, illetve $\mathrm{NiO}$ (bunzenit)) jelentek meg. Ezek a fém-oxid klaszterek részben elzárták a pórusokat, ami a felület csökkenését eredményezte. A fajlagos felület kezdetben $218-285 \mathrm{~m}^{2} / \mathrm{g}$ volt a módosító fémtől és a beépítés módjától függően, de a használat során a csatornákba bepolimerizálódott glicerin jelentősen csökkentette azt, illetve a reflexiók intenzitása is kismértékben csökkent, valamint a $\mathrm{Cu}$-ZSM5 esetén a $\mathrm{CuO}$ átalakult $\mathrm{Cu}_{2} \mathrm{O}$-dá.

Fontos tényező, hogy a ZSM-5 zeolitok termostabilis anyagok, ezért a koksz leégetésére alkalmazható a $600{ }^{\circ} \mathrm{C}$-os levegő (vagy oxigén) atmoszférában végbemenő izzítás, melynek során a használatkor $\mathrm{CuO}$-ból átalakult $\mathrm{Cu}_{2} \mathrm{O}$ is részben visszaalakul $\mathrm{Cu}(\mathrm{II})$-oxiddá.

Az adszorpciós izotermák és azok hiszterézise alapján tudhatjuk, hogy a szilárdfázisú ioncserével létrehozott mintákban (főképp CuZSM-5) csak mezopórusok vannak, míg a többi zeolitban a pórusszerkezet hasonló. és a résszerü mezopórusok mellett mikropórusok is jelen vannak.

A használat előtti Raney-nikkel 222A és 222B röntgendiffraktogramja, fázisösszetétele és fajlagos felülete, nitrogén-fiziszorpciós izotermája megegyezik, és derivatogramjuk is hasonló, azonban a $222 \mathrm{C}$ minta ezektől eltér. Ebböl arra következtethetünk, hogy 50 és $120{ }^{\circ} \mathrm{C}$ között ezekkel a módszerekkel kimutatható változás nem történt, míg $120-320{ }^{\circ} \mathrm{C}$ hőmérsékleten vízvesztéssel a gibbsit, bayerit és nordstrandit egy része böhmitté alakul át, és megnő az alumínium-nikkel aránya. Mivel a böhmit szemcsemérete kisebb, a 222C fajlagos felülete megnő $\left(73 \mathrm{~m}^{2} / \mathrm{g}\right.$, míg a 222A és -B felülete $\left.28 \mathrm{~m}^{2} / \mathrm{g}\right)$. A használatlan Raney-nikkeleket 600 
${ }^{\circ} \mathrm{C}$-on hökezelve, a 222-es sorozat tagjainak esetén egymással azonos mintákat kaptam, melyekben a trihidrátok és a böhmit átalakultak $\mathrm{Al}_{2} \mathrm{O}_{3}$-dá, $\mathrm{s}$ így az alumínium-nikkel jelenléte még hangsúlyosabbá vált.

A reakció során az alumíniumtartalmú mintáknál az intermetallikus $\mathrm{AlNi}$ és $\mathrm{Al}_{3} \mathrm{Ni}_{2}$ (egy kevés alumínium-oxihidráttal együtt) szétvált „hordozójától” (a továbbiakban: maradék), és mágneses tér segítségével két részre tudtam szeparálni őket. A szétvált részek fajlagos felülete jelentősen csökkent a használatlan formához képest.

A RNi-212 típusú esetén a kiinduló anyag szórásképéhez képest sem a használat, sem a $600{ }^{\circ} \mathrm{C}$-os hőkezelés nem idézett elő kimutatható mértékű változást. Utóbbi összhangban van azzal, hogy a termogravimetriás mérések sem mutattak tömegcsökkenést az adott hőmérséklet-tartományban, ezért megfelelő módszernek adódott az, hogy a használat után ilyen módon regeneráljam a mintákat.

A röntgendiffrakciós felvételek alapján valamennyi tesztelt hidrotalcitra igaz, hogy a hökezelésbeli eltérés nem okoz szinte semmilyen különbséget a szerkezetben. A frissen előállított hidrotalcitok felülete a hőkezelés hatására az eltávozó $\mathrm{CO}_{2}$ és a $\mathrm{H}_{2} \mathrm{O}$ eredményeképp bekövetkező kráterképződés miatt nőtt. Ezt alátámasztják a nitrogénadszorpciós és a termogravimetriás mérések is. A hidrotalcitok bomlása három lépésben valósult meg. Kezdetben $\left(<85^{\circ} \mathrm{C}\right)$ elvesztette az adszorbeálódott, majd $\left(85-220^{\circ} \mathrm{C}\right)$ a rétegek közötti vizet. Végül a rétegek dehidroxileződéséből adódó tömegvesztés $405^{\circ} \mathrm{C}$-on fejeződött be. A különböző módosító fémek bevitele egyrészt a minták termikus stabilitását, másrészt azok fajlagos felületét is csökkentette. A glicerin dehidratálási reakciói során a réteges szerkezet részben vagy teljesen visszaképződött, és az újra hőkezelt LDH-k hasonló aktivitású keverékoxidokat eredményeztek, mint amilyenek a frissen szintetizált LDH-kból hőkezeléssel kapott keverékoxidok voltak.

Amikor a glicerin dehidratálódási reakcióit hozzáadott szilárd anyag nélkül végeztem, akkor a konverzió $30 \%$ körül volt és 1/3:1/3 arányban keletkezett acetaldehid és acetol. A ZSM-5 zeolitok alkalmazásával a konverzió ennél alacsonyabb (Cu-, Ti-ZSM-5) vagy hasonló (H-, CrZSM-5) volt, csak a Ni-tartalmú minták növelték az átalakulást (54-55 \%). A főtermék aránya általában nem sokkal haladta meg a melléktermékekét. Ez alól szintén a NiZSM-5 képez kivételt a $80 \%$ feletti szelektivitásával, viszont a keletkező acetaldehid a potenciális termékek közül a legkevésbé értékes. Bár a Cu-ZSM5 58 \% szelektivitással segítette elő az acetol képződését, a glicerin konverziója ebben az esetben csak 14 \% volt.

Az új típusú Raney-nikkelek lényegesen nagyobb aktivitást mutattak és a szelektivitásuk is kedvezőbb volt, mint a ZSM-5-katalizátoroké. Az acetol a fötermék minden esetben, melynek 
arányát egyetlen más termék sem közelítette meg. Az acetol és az akrolein együttes mennyisége 74-80\% volt, olykor azonban a $95 \%$-ot is meghaladta, míg a degradációs termékek aránya elenyésző volt. A legjobb eredményt a RNi-212 esetén tapasztaltam, ahol a $82 \%$ konverzióhoz $70 \%$ acetolszelektivitás párosult. A 222A és 222B minták is figyelemre méltóak a $72-$ $75 \%$ konverzióval és 72-74 \% acetolszelektrivitással, de sajnos az Al-tartalmú Raney-nikkelek nem regenerálhatók, így nem is tekinthetök valódi katalizátornak. Szerencsére azonban a Si-tartalmú Raney-nikkel egy egyszerü hőkezeléssel könnyen és hatékonyan regenerálható volt, így ez az anyag a glicerin dehidratálásának hatásos katalizátorának bizonyult.

A hidrotalcitokból előállított keverékoxidok esetén az előkezelés hőmérséklete nem volt jelentős befolyással a katalizátorok müködésére. A módosítatlan (MgAl), Ni- és Cr-LDH-ból készült keverékoxidok esetén közepes aktivitás (46-54 \%) mellett magas (79-82\%) acetolszelektivitást értem el. Ezzel szemben a réz jelentősen növelte a konverziót $(90 \%<$ ), viszont jelenlétében csökkent az acetol aránya ( 67\%) a termékelegyben. A két fémmel módosított CuCr-LDH egyesíti a réz által elősegített magas konverzió, és a króm okozta magas acetolszelektivitás elönyeit.

A frissen szintetizált LDH-kból hőkezeléssel készített keverékoxidok a dehidratálási reakciók során keletkezett víz hatására részben vagy teljesen visszanyerték réteges szerkezetüket, reményt nyújtva arra, hogy ezt a jelenséget egy újabb hőkezeléssel kombinálva egy hatékony regenerálási módszerhez jutunk. Reményeink teljesültek a MgAl- és a NiMgAl-LDH esetén, míg a CrMgAl- a CuMgAl- és a CuCrMgAl-keverékoxidok esetén a réteges szerkezet csak részben állt vissza, így az újbóli hőkezelés eredményeként más szerkezetű és tulajdonságokkal rendelkező keverékoxidokat kaptunk.

A doktori értekezés témájának környezeti kémiai technológiai jelentősége van, bár eredményei az alapkutatás körébe tartoznak. A vizsgált katalizátorok közül az aktivitást, szelektivitást és a regenerálhatóságot is figyelembe véve a Si-tartalmú Raney-nikkel és a MgAl-, illetve NiMgAl-LDH-kból nyert keverékoxidok bizonyultak ígéretesnek, így érdemesek lehetnek további kutatásokra. Bár egyetlen reakciót tekintve a legkedvezőbb glicerinkonverziót és acetolszelektivitást $\mathrm{CuCrMgAl}$ keverékoxid eredményezte, sajnos az anyag nem regenerálható, így katalizátornak sem tekinthető. 


\section{Summary}

The aim of my doctoral research was to find suitable method, catalyst and reaction conditions to make products of high value from glycerol, which is a byproduct inevitably formed during the current technologies of biodiesel production. To increase the commercial viability of biodiesel production, utilization of by-products is necessary. Inspite of the fact that large amounts of glycerol are used in industry, the predicted increase in biodiesel production will surely create an oversupply of glycerol market, therefore its price will fall. For this reason and in order to avoid the possible waste problem, converting glycerol to other valuable products is highly desirable.

Among the several conversion methods, dehydration was chosen as the subject of this research. It was carried out by the reactive distillation method, which is beneficial due to the continuous separation of products, thereby the selectivity could be enhanced. High amounts of acetol and/or acrolein could be produced, which can be used in food, pharmaceutical, chemical industry as well as in cosmetics and can be hydrogenated to obtain the even more precious propanediols.

The applied potential catalysts were zeolites ZSM-5, new type of (non-pyrophoric) Raneynickel samples and mixed oxides obtained with the calcination of hydrotalcites.

NaZSM-5 was used for the preparation of modified zeolites like the $\mathrm{Cu}$ - and $\mathrm{Ni}$-containing samples made by solid-state, the Cr- and NiZSM-5-f by conventional ion exchange and TiZSM-5 by isomorphic substitution of $\mathrm{Al}^{3+}$ to $\mathrm{Ti}^{4+}$.

The new type of Raney-nickel catalysts were donated by the inventors in order to test their properties in various reaction types. From the $\mathrm{Ni}-\mathrm{Al}$ alloy powder the aluminium was partially dissolved by $\mathrm{NaOH}$, and in some cases they were also heat treated. These samples (222A, -B, -C) can be considered as Al-(oxy)hydrate supported nickel-aluminium [ $\mathrm{NiAl}-\mathrm{Ni}_{2} \mathrm{Al}_{3} / \mathrm{Al}_{\mathrm{x}} \mathrm{OH}_{\mathrm{y}}$. When silicon was used instead of aluminium, Si supported nickel-silicide (sample 212) could be produced.

The hydrotalcite samples were synthesized by the co-precipitation of aqueous solutions of $\mathrm{Al}\left(\mathrm{NO}_{3}\right)_{3} \cdot 9 \mathrm{H}_{2} \mathrm{O}+\mathrm{Mg}\left(\mathrm{NO}_{3}\right)_{2} \cdot 6 \mathrm{H}_{2} \mathrm{O}$ and $\mathrm{Na}_{2} \mathrm{CO}_{3}+\mathrm{NaOH}$ under basic conditions. The $\mathrm{MgAl}$ hydrotalcite was modified by the partial $(10 \%)$ replacement of $\mathrm{Mg}^{2+}$ and $\mathrm{Al}^{3+}$ to $\mathrm{Ni}^{2+}, \mathrm{Cu}^{2+}$ and $\mathrm{Cr}^{3+}$ with the substitution of the appropriate metal nitrate. The washed, filtered and dried samples were calcined at $400{ }^{\circ} \mathrm{C}, 500{ }^{\circ} \mathrm{C}$ or $600{ }^{\circ} \mathrm{C}$ in order to obtain the corresponding mixed oxides.

The catalysts were characterized by X-ray diffractometry (XRD), nitrogen physisorption 
(BET) and thermogravimetric (TG) methods. The products formed and the distillation residue were analyzed by gas chromatography (GC).

The XRD patterns of all zeolites show the reflexions of ZSM-5 (MFI) structure without considerable changing caused by the modifications. In the case of the samples prepared by solid-state ion exchange (Cu- and NiZSM5-sz) decrease of intensity and the appearance of $\mathrm{CuO}$ and $\mathrm{NiO}$ (bunsenite) could be observed. These clusters partially blocked the pores, thus decreasing the surface area. BET measurements revealed that the samples synthesized by the solid-state ion exchange method were mesoporous, while in the other samples along with the slit-shaped mesopores micropores could also be observed. The calcined samples are thermostable, therefore can be regenerated by oxidation at high temperature.

In the Raney-Ni catalysts as the aluminium was just partially dissolved, the formed trihydrates (bayerite, gibbsite and nordstrandite) became the support of the intermetallic aluminium-nickel ( $\mathrm{AlNi}, \mathrm{Al}_{3} \mathrm{Ni}_{2}$ ), this way the $\mathrm{Ni}$-dispersion could be enhanced, thus the pyrophoric character could be avoided.

Data of XRD and TG measurements revealed that the structure of the aluminiumcontaining Raney-Ni catalyst did not change between $50{ }^{\circ} \mathrm{C}(222 \mathrm{~A})$ and $120{ }^{\circ} \mathrm{C}(222 \mathrm{~B})$. However, in the $120-320^{\circ} \mathrm{C}$ temperature range (222C) water loss took place resulting in the partial transformation of gibbsite, bayerite and nordstrandite to boehmite having smaller particle size, thus, higher specific surface area. Further increase in temperature $\left(600{ }^{\circ} \mathrm{C}\right)$ converted the trihydrates and boehmite to $\mathrm{Al}_{2} \mathrm{O}_{3}$ giving even higher proportion of aluminiumnickel. BET isotherms (type IV with loop H3) verified the presence of plate-like particles and slit-shaped mesopores in all Al-containing Raney-Ni samples, and in catalysts 222A and 222B micropores could be observed as well. The Si-containing RNi-212 was less porous, thus the deactivation was less predominant.

During the reaction the intermetallic aluminium-nickel ( $\mathrm{AlNi}$ and $\mathrm{Al}_{3} \mathrm{Ni}_{2}$ ) spontaneously departed from its support and the two phases could be separated with magnetic field.

The Si-containing Raney-Ni sample did not show structural changes either in the the dehydration reaction of glycerol or after calcination at $600{ }^{\circ} \mathrm{C}$. It is in correspondence with the observation that heat treatment did not result in any mass loss.

The XRD patterns of as-prepared layered double hydroxides revealed the formation of $\mathrm{Mg}_{6} \mathrm{Al}_{2}(\mathrm{OH})_{16}\left(\mathrm{CO}_{3}\right) \cdot 4 \mathrm{H}_{2} \mathrm{O}$ (hydrotalcite, $\mathrm{HT}$ ) and $\mathrm{MgO}$ (periclase) and the appropriate metal oxide, respectively.

The unmodified and Ni-containing samples are well-crystallized, while for the other 
samples $(\mathrm{Cu}-, \mathrm{Cr}-, \mathrm{CuCr}-\mathrm{HT})$ some losses in crystallinity could be observed. The layered structure collapsed on heat-treatment forming mixed oxides already at $400{ }^{\circ} \mathrm{C}$ and further increase in temperature did not alter the structure notably.

The experimental results of nitrogen physisorption and thermogravimetric measurements showed that due to craterization taking place via the elimination of $\mathrm{CO}_{2}$ and $\mathrm{H}_{2} \mathrm{O}$, the surface area increased in the calcined samples compared to the fresh ones. According to the thermogravimetric analysis decomposition of hydrotalcites occurred in three steps. First the adsorbed water then the interlayer water was eliminated, finally, the dehydroxylation of the layers was completed by $405{ }^{\circ} \mathrm{C}$. The incorporation of modifiers reduced the stability of the hydrotalcite, decomposition of the samples started at lower temperature, the particle size of $\mathrm{MgO}$ increased lowering the specific surface area.

The freshly prepared and calcined LDHs partially or fully regained their layered structures during the dehydration reaction due to the water formed, and after recalcination the obtained mixed oxide displayed similar behaviour to the ones obtained via the calcination of the freshly prepared samples.

In the dehydration reactions of glycerol performed without added solid material, the conversion was $30 \%$, and 33-33\% of acetaldehyde and acetol were formed.

In the presence of ZSM-5 samples the conversion was generally lower (Cu-, Ti-ZSM-5) or similar (H- and CrZSM-5) to the reaction taking place in absence of catalyst. Over CrZSM-5 acrolein became a major product and acetol and the less preferred acetaldehyde, the degradation and cyclic components were by-products. In the presence of zeolite HZSM-5 $24 \%$ conversion could be reached and the formation of acetol and acrolein occurred with similar ratio (30-32\%). Acetaldehyde and cyclic components were also formed as by-products. Over NiZSM-5 the conversion could be increased (55\%), but acetaldehyde was mainly (78-83\%) formed. Over CuZSM-5 the selectivity of acetol was enhanced (58\%), however, the conversion was low (14\%). In the presence of Ti-ZSM-5 conversion was similar, but the composition of distillate was less favourable with acetaldehyde $(47 \%)$ as the main product.

Over the new type of Raney-nickel catalysts high activity and acetol selectivity could be achieved and the ratio of degradation products was negligible. The best values were $82 \%$ conversion with $70 \%$ of acetol selectivity observed in the presence of RNi-212. RNi-222A and $222 \mathrm{~B}$ are also worth mentioning with 72-75\% conversion and 72-74\% acetol selectivity. However, the RNi-222C could enhance the selectivity ( $87 \%)$, the conversion (49 $\%$ ) was dropped compared with the other samples. Unfortunately, these matrials could not be 
regenerated, therefore they cannot be regarded as catalysts. The best values were $82 \%$ conversion with $70 \%$ of acetol selectivity observed in the presence of Si-containing Raneynickel (RNi-212) and it could be regenerated with simple calcination at $600{ }^{\circ} \mathrm{C}$ with ease, thus it was a catalyst of the dehydration process, indeed.

The temperature of heat treatment did not influence significantly the catalytic behaviour of the mixed oxides. Over the unmodified, $\mathrm{Ni}$ - and $\mathrm{Cr}$-containing samples moderate activity (46$54 \%$ ) but high acetol selectivity (79-82\%) could be observed. The presence of $\mathrm{Cu}$ increased the conversion significantly (above $90 \%$ ), but decreased the proportion of acetol $(\sim 67 \%)$ in the distillate. The calcined $\mathrm{CuCr}-\mathrm{LDH}$ combined both the advantageous effects of $\mathrm{Cu}$ (facilitating high conversion) and $\mathrm{Cr}$ (promoting remarkable acetol selectivity). Unfortunately, these latter three materials could not be regenerated, since their lamellar structures were only partially restored during the reaction, and thus recalcination produced mixed oxides with structures differing from those obtained after the first calcination. Thus. they cannot be considered as catalysts of glycerol dehydration.

However, the lamellar structure of the unmodified and the Ni-containing catalysts could be fully restored. After recalcination, these samples were used in a repeated reaction, where the activity decrease was slight and the product distribution was similar to that over the freshly prepared samples.

The topic of the theses has an importance in the field of environmental chemistry, however the results may be considered as fundamental research. Regarding the activity, selectivity and the possibility of regeneration, the Si-containing Raney-nickel and the calcined MgAl- and NiMgAl-LDHs are the most promising samples among the investigated materials. 


\section{Köszönetnyilvánítás}

Elsősorban köszönöm témavezetőimnek, dr. Halász János címzetes egyetemi tanárnak a munkám minden területén nyújtott segítségét, a kísérletek megtervezetésétől kezdve az eredmények értelmezésén át azok publikálásáig. Hálával tartozom dr. Pálinkó István egyetemi docensnek, az MTA doktorának, aki rengeteg szakmai segítséget nyújtott az eredmények értékelésében és publikálásában.

Köszönöm néhai dr. Kiricsi Imre valamint dr. Kónya Zoltán tanszékvezető egyetemi tanároknak, amiért lehetővé tették, hogy az Alkalmazott és Környezeti Kémiai Tanszéken végezhessem a doktori disszertáció megírásához szükséges munkát.

Ezúton szeretnék köszönetet mondani a tanszék összes dolgozójának, akik minden tőlük telhető segítséget megadtak, hogy a dolgozat elkészülhessen.

Különösen hálás vagyok Asbóth Csabának a kísérletek során használt üvegeszközök biztosításáért, szükség esetén pótlásáért és a lelkesítő beszélgetésekért.

Köszönettel tartozom néhai Petró József professzornak és Sajó Istvánnak, akikre az alkalmazott katalizátorokkal, azok szerkezeti vizsgálataival kapcsolatosan felmerülő kérdések értelmezésében bármikor számíthattam.

Végül, de nem utolsó sorban szeretnék köszönetet mondani családomnak és barátaimnak hogy hosszú időn át mindvégig támogattak, mellettem álltak, megértettek és türelemmel elviseltek. 


\section{Irodalomjegyzék}

1. European Biodiesel Board; http://www.ebb-eu.org/; utolsó letöltés ideje: 2013. 10. 28.

2. http://eur-lex.europa.eu/LexUriServ/LexUriServ.do?uri=DD:13:31:32003L0030:HU:PDF; utolsó letöltés ideje: 2013. 10. 28.

3. http://eur-lex.europa.eu/LexUriServ/LexUriServ.do?uri=DD:13:23:31998L0070:HU:PDF; utolsó letöltés ideje: 2013. 10. 28.

4. http://www.euractiv.com/transport/review-eu-fuel-quality-directive/article-167990; utolsó letöltés ideje: 2013. 10. 28.

5. Renewable Energy Directive 2009/28 (RED); http://eur-lex.europa.eu/LexUriServ/LexUriServ.do?uri=OJ:L:2009:140:0016:0062:HU:PDF; utolsó letöltés ideje: 2013. 10. 28.

6. http://eur-lex.europa.eu/LexUriServ/LexUriServ.do?uri=OJ:L:2009:140:0088:0113:HU:PDF; utolsó letöltés ideje: 2013. 10. 28.

7. http://www.euractiv.com/transport/biofuels-transport/article-152282; utolsó letöltés ideje: 2013. 10. 28.

8. Gyulai I.: A biomassza dilemma - Magyar Természetvédők Szövetsége 2006.

9. Hancsók J., Kovács F.: A Biodízel; BME OMIKK Környezetvédelmi Füzetek, Budapest, 2002. január, 56 oldal

10. D. Pimentel, T. W. Patzek; Natural Resources Research, 14 (2005) 65.

11. University of Strathclyde Engineering, Energy Systems Research Unit; http://www.esru.strath.ac.uk/EandE/Web_sites/02-03/biofuels/what_biodiesel.htm; utolsó letöltés ideje: 2013. 10. 28.

12. R. S. Karinen, A. O. I. Krause; Appl. Catal. A: Gen. 306 (2006) 128.

13. V. L. C. Gonçalves, B. P. Pinto, J. C. Silva, C. J. A. Mota; Catal. Today 133-135 (2008) 673.

14. F. Ma, M. A. Hanna; Biores. Technol. 70 (1999) 1.

15. Ghent Bio-energy Valley; http://www.gbev.org/en/bioenergie.asp?lng=en\&id=11\&nid=; utolsó letöltés ideje: 2008.07.18.

16. Puppán D.: Bioüzemanyagok - A biodízel és a bioetanol mint alternatív motorikus üzemanyag; Magyar Tudomány 2001/11.

17. L. C. Meher, D. V. Sagar, S. N. Naik; Renew. Sustain. Energy Rev. 10 (2006) 248.

18. L. Edgar, Y. Liu, D. E. Lopez, S. Kaewta, D. A. Bruce, J. G. Goodwin; Ind. Eng. Chem. Res. 44 (2005) 5353.

19. E. Minami, S. Saka; Fuel 85 (2006) 2479.

20. Y. Shimada, Y. Watanabe, A. Sugihara, Y. Tominaga; J. Mol. Catal. B: Enzym. 17 (2002) 133.

21. S. Furuta, H. Matsuhashi, K. Arata; Catal. Commun. 5 (2004) 721.

22. K. Narasimharao, D. R. Brown, A. F. Lee, A. D. Newman, P. F. Siril, S. J. Tavener, K. Wilson; J. Catal. 248 ( 2007) 226.

23. M. Toda, A. Takagaki, M. Okamura, J. N. Kondo, S. Hayashi, K. Domen, M. Hara; Nature 438 (2005) 178.

24. A. A. Kiss, A. C. Dimian, G. Rothenberg; Adv. Synth. Catal. 348 (2006) 75.

25. T. Sakai, A. Kawashima, T. Koshikawa; Biores. Technol. 100 (2009) 3268.

26. W. Xie, H. Peng, L. Chen; Appl. Catal. A: Gen. 300 (2006) 67. 
27. G. J. Suppes, M. A. Dasari, E. J. Doskocil, P. J. Mankidy, M. J. Goff; Appl. Catal. A: Gen. 257 (2004) 213.

28. D. G. Cantrell, L. J. Gillie, A. F. Lee, K. Wilson; Appl. Catal. A: Gen. 287 (2005) 183.

29. N. Shibasaki-Kitakawa, H. Honda, H. Kuribayashi, T. Toda, T. Fukumura, T. Yonemoto; Biores. Technol. 98 (2007) 416.

30. G. R. Peterson, W. P. Scarrah; J. Am. Oil Chem. Soc. 61 (1984) 1593.

31. Herseczki Zs., Marton Gy.: Preparation of tripropionin from crude glycerol the byproduct of biodiesel production and field of application; http://www.veab.mta.hu/Veabinno/Osszefoglalok/Herseczki_Zs.pdf; utolsó letöltés ideje: 2013. 10. 28

32. M. Stelmachowski; Ecological Chemistry and Engineering 18 (2011) 9.

33. Twelve Principles of Green Chemistry; http://www.epa.gov/sciencematters/june2011/principles.htm; utolsó letöltés ideje: 2013. 10. 28.

34. K. Klepáčová, D. Mravec, M. Bajus; Appl. Catal. A: Gen. 294 (2005) 141.

35. K. Klepáčová, D. Mravec, A. Kaszonyi, M. Bajus; Appl. Catal. A: Gen. 328 (2007) 1.

36. J.-M. Clacens, Y. Pouilloux, J. Barrault; Appl. Catal. A: Gen. 227 (2002) 181.

37. J.-M. Clacens, Y. Pouilloux, J. Barrault, C. Linares, M. Goldwasser; Stud. Surf. Sci. Catal. 118 (1998) 895.

38. A. Corma, S. Iborra, S. Miquel, J. Primo; J. Catal. 173 (1998) 315.

39. N.O.V. Sonntag; J. Am. Oil Chem. Soc. 59 (1982) 795A.

40. M. da S. Machado, J. Pérez-Pariente, E. Sastre, D. Cardoso, A.M. de Guereñu; Appl. Catal. A: Gen. 203 (2000) 321.

41. A. Corma, H. García, S. Iborra, J. Primo; J. Catal. 120 (1989) 78.

42. Y. Pouilloux, S. Abro, C. Vanhove, J. Barrault; J. Mol. Catal. A: Chem. 149 (1999) 243.

43. J. Barrault, Y. Pouilloux, J. M. Clacens, C. Vanhove, S. Bancquart; Catal. Today 75 (2002) 177.

44. C. Henry; Cereal Foods World 40 (1995) 734.

45. M. M. Rieger; Cosmetics and Toiletries 105 (1990) 51.

46. H. Nabeshima, K. Ito; JP patent 276787 (1995).

47. S. Nomura, T. Hyoshi; JP patent 203429 (1995).

48. Y. Taguchi, A. Oishi, Y. Ikeda, K. Fujita, T. Masuda; JP patent 298099 (2000).

49. R. R. Soares, D. A. Simonetti, J. A. Dumesic; Angew. Chem. Int. Ed. 45 (2006) 3982.

50. B. Zhang, X. Tang, Y. Li, Y. Xu, W. Shen; Internat. J. Hydr. Energy 32 (2007) 2367.

51. G. W. Huber, J. W. Shabaker, J. A. Dumesic; Science 300 (2003) 2075.

52. J. W. Shabaker, G. W. Huber, J. A. Dumesic; J. Catal. 222 (2004) 180.

53. M. Aresta, A. Dibenedetto, F. Nocito, C. Pastore; J. Mol. Catal. A: Chem. 257 (2006) 149.

54. V. Plasman, T. Caulier, N. Boulos; Plast. Addit. Compd. 7 (2005) 30.

55. M. Klumpe; Oleochemicals under Changing Global Conditions, DGF-meeting, Hamburg, Németország (2007).

56. A. Behr, J. Eilting, K. Irawadi, J. Leschinski, F. Lindner; Green Chem. 10 (2008) 13.

57. S. Demirel-Gülen, M. Lucas, P. Claus; Catal. Today 102-103 (2005) 166. 
58. S. Demirel, K. Lehnert, M. Lucas, P. Claus; Appl. Catal. B: Environ. 70 (2007) 637.

59. N. Teruyuki, K. Yoshinori; JP Patent 01168292 (1989).

60. R. Garcia, M. Besson, P. Gallezot; Appl. Catal.A: Gen. 127 (1995) 165.

61. N. Dimitratos, C. Messi, F. Porta, L. Prati, A.Villa; J. Mol. Catal. A: Chem. 256 (2006) 21.

62. N. Dimitratos, A. Villa, C. L. Bianchi, L. Prati, M. Makkee; Appl. Catal. A: Gen. 311 (2001) 185.

63. E. Tsukuda, S. Sato, R. Takahashi, T. Sodesawa; Catal. Commun. 8 (2007) 1349.

64. W. Suprun, M. Lutecki, T. Haber, H. Papp; J. Mol. Catal. A: Chem. 309 (2009) 71.

65. S.-H. Chai, H.-P. Wang, Y. Liang, B.-Q. Xu; Green Chem. 9 (2007) 1130.

66. M. J. Antal, W. S. L. Mok, J. C. Roy, A. T. Raissi; J. Analyt. Appl. Pyrol. 8 (1985) 291.

67. S. Sato, M. Akiyama, R. Takahashi, T. Hara, K. Inui, M. Yokota; Appl. Catal. A: Gen. 347 (2008) 186.

68. M. Pagliaro, R. Ciriminna, H. Kimura, M. Rossi, C. D. Pina; Angew. Chem. Int. Ed. 46 (2007) 4434.

69. S.-H. Chai, H.-P. Wang, Y. Liang, B.-Q. Xu; J. Catal. 250 (2007) 342.

70. Y. T. Kim, K. D. Jung, E. D. Park; Micropor. Mesopor. Mat. 131 (2010) 28.

71. M. H. Mohamad, R. Awang, W. M. Z. W. Yunus; Am. J. Applied Sci. 8 (2011) 1135.

72. J. Deleplanque, J.-L. Dubois, J.-F. Devaux,W. Ueda; Catal. Today 157 (2010) 351.

73. S. Ramayya, A. Brittain, C. DeAlmeida, W. Mok, M. J. Antal Jr; Fuel 66 (1987) 1364.

74. M. Watanabe, T. Iida, Y. Aizawa, T. M. Aida, H. Inomata; Biores. Technol. 98 (2007) 1285.

75. W. Bühler, E. Dinjus, H. J. Ederer, A. Kruse, C. Mas; J. Supercrit. Fluids 22 (2002) 37.

76. L. Ott, M. Bicker, H. Vogel; Green Chem. 8 (2006) 214.

77. H. Atia, U. Ambruster, A. Martin; J. Catal. 258 (2008) 71.

78. Y. T. Kim, K-D. Jung, E. D. Park; Appl. Catal. A: Gen. 393 (2011) 275.

79. M. R. Nimlos, S. J. Blanksby, X. Qian, M. E. Himmel, D. K. Johnson; J. Phys. Chem. A 110 (2006) 6145.

80. C.-W. Chiu, M. A. Dasari, G. J. Suppes, W. R. Sutterlin; AlChE J. 52 (2006) 3543.

81. Y. Nakagawa, K. Tomichige; Catal. Sci. Technol. 1 (2011) 179.

82. E. D’Hondt, S. Van de Vyver, B. F. Sels, P. A. Jacobs; Chem. Commun. 45 (2008) 6011.

83. J. Chaminand, L. Djakovitch, P. Gallezot, P. Marion, C. Pinel, C. Rosier; Green Chem. 6 (2004) 359.

84. M. A. Dasari, P. P. Kiatsimkul, W. R. Sutterlin, G. J. Suppes; Appl. Catal. A: Gen. 281 (2005) 225.

85. P. N. Caley, R. C. Everett; US Patent 3350871 (1967) DuPont.

86. D. Zimmerman, R. B. Isaacson; US Patent 3814725 (1974) Celanese Corp.

87. M. M. Zhu, P. D. Lawman, D. C. Cameron; Biotechnol. Prog. 18 (2002) 694.

88. A. Perosa, P. Tundo; Ind. Eng. Chem. Res. 44 (2005) 8535.

89. J. Feng, H. Fu, J. Wang, R. Li, H. Chen, X. Li; Catal. Commun. 9 (2008) 1458.

90. E. P. Maris, R. J. Davis; J. Catal. 249 (2007) 328.

91. E. P. Maris, W. C. Ketchie, M. Murayama, R. J. Davis; J. Catal. 251 (2007) 281.

92. C. Montassier, J. C. Ménézo, L. C. Hoang, C. Renaud, J. Barbier; J. Mol. Catal. 70 (1991) 99. 
93. Z. Yuan, J. Wang, L. Wang, W. Xie, P. Chen, Z. Hou, X. Zheng; Biores. Technol. 101 (2010) 7088 .

94. Z. Yuan, P. Wu, J. Gao, X. Lu, Z. Hou, X. Zheng; Catal. Lett. 130 (2009) 261.

95. I. Furikado, T. Miyazawa, S. Koso, A. Shimao, K. Kunimori, K. Tomishige; Green Chem. 9 (2007) 582.

96. V. Lehr, M. Sarlea, L. Ott, H. Vogel; Catal. Today 121 (2007) 121.

97. Y. Kusunoki, T. Miyazawa, K. Kunimori, K. Tomishige; Catal. Commun. 6 (2005) 645.

98. T. Miyazawa, Y. Kusunoki, K. Kunimori, K. Tomishige; J. Catal. 240 (2006) 213.

99. T. Miyazawa, S. Koso, K. Kunimori, K. Tomishige; Appl. Catal. A: Gen. 318 (2007) 244.

100. T. Miyazawa, S. Koso, K. Kunimori, K. Tomishige; Appl. Catal. A: Gen. 329 (2007) 30.

101. A. Alhanash, E. F. Kozhevnikova, I. V. Kozhevnikov, Catal. Lett. 120 (2007) 307.

102. L. Huang, Y. Zhu, H. Zheng, G. Ding, Y. Li; Catal. Lett. 131 (2009) 312.

103. C. Montassier, D. Giraud, J. Barbier; Stud. Surf. Sci. Catal. 41 (1988) 165.

104. D. G. Lahr, B. H. Shanks; J. Catal. 232 (2005) 386.

105. L. Guo, J. Zhou, J. Mao, X. Guo, S. Zhang; Appl. Catal. A: Gen. 367 (2009) 93.

106. E. D'Hondt, S. Van de Vyver, P. A. Jacobs, B. F. Sels; http://nam.confex.com/data/abstract/nam/2009/Paper 2363 abstract 835 0.pdf; utolsó letöltés ideje: 2013. 10. 28.

107. W. Yu, J. Zhao, H. Ma, H. Miao, Q. Song, J. Xu; Appl. Catal. A: Gen. 383 (2010) 73.

108. N. Ueda, Y. Nakagawa, K. Tomishige; Chem. Lett. 39 (2010) 506.

109. Q. Liu, X. Guo, Y. Li, W. Shen; Langmuir 25 (2009) 6425.

110. S. Wang, H. Liu; Catal. Lett. 117 (2007) 62.

111. M. J. Kelly, H. H. Lamb; http://www.nacatsoc.org/21nam/data/papers/Paper2834.pdf.

112. S.-L. Hao, W.-C. Peng, N. Zhao, F.-K. Xiao, W. Wei, Y.-H. Suna; J. Chem. Technol. Biotechnol. 85 (2010) 1499.

113. T. Kurosaka, H. Maruyama, I. Naribayashi, Y. Sasaki; Catal. Commun. 9 (2008) 1360.

114. M. Schlaf, P. Ghosh, P. J. Fagan, E. Hauptman, R. M. Bullock; Angew. Chem. Int. Ed. 40 (2001) 3887.

115. A. K. Kolah, N. S. Asthana, D. T. Vu, C. T. Lira, D. J. Miller; Ind. Eng. Chem. Res. 47 (2008) 1017.

116. J. B. Nagy, P. Bodart, I. Hannus, I. Kiricsi; Synthesis, characterization and use of zeolitic microporous materials, DecaGen Ltd., Szeged (1998).

117. D.W. Breck; Zeolite Molecular Sieves, Structure, Chemistry, Use; John Wiley and Sons, New York (1974).

118. D. Barthomeuf; Information Chimie 295 (1988) 227.

119. D. M. Ruthven; Chem. Eng. Prog. 84 (1988) 42.

120. R. J. Argauer, M. Kensington, G. R. Landolt; US Patent 3702886 (1972).

121. W. Ding, G. Meitzner, E. Iglesia; J. Catal. 206 (2002) 14.

122. Ch. Baerlocher, L. B. McCusker, D.H. Olson: Atlas Of Zeolite Framework Types, $6^{\text {th }}$ revised edition (2007). 
123. Ch. Baerlocher, L. B. McCusker, Database of Zeolite Structures; http://izasc.ethz.ch/fmi/xsl/IZA-SC/ftc fw.xsl?-db=Atlas main\&-lay=fw\&max=25\&STC=MFI\&-find; utolsó letöltés ideje: 2013. 10. 28.

124. T. Armaroli, L. J. Simon, M. Digne, T. Montanari, M. Bevilacqua, V. Valtchev, J. Patarin, G. Busca; Appl. Catal. A: Gen. 306 (2006) 78.

125. G. Busca; Chem. Rev. 107 (2007) 5366.

126. C. Falamaki, M. Edrissi, M. Sohrabi; Zeolites 19 (1997) 2.

127. J. Hinoto, S. Kanejima; Zeolites, 17 (1996) 321.

128. H. van Bekkum, E. M. Flanigen, P. A. Jacobs, J. C. Jansen; Introduction to zeolite science and practice, Elsevier Publ. Co., Amsterdam ( 2001).

129. R. B. Borade, A. Clearfield; Zeolites 14 (1994) 458.

130. A. Tuel, Y. Bentarrity; Ibid. 13 (1993) 357.

131. D. Zhao, S. Qiu, W. Pang, Zeolites 13 (1993) 478.

132. J. A. Gharamaleki, F. Farzaneh, M. Ghandi; J. Sci. I. R. Iran 15 (2004) 39.

133. C. Zenonos, G. Sankar, J. García-Martínez, A. Aliev, A. M. Beale; Catal. Lett. 86 (2003) 279.

134. L. Shirazi, E. Jamshidi, M. R. Ghasemi; Cryst. Res. Technol. 43 (2008) 1300.

135. G. I. Panov, A. K. Uriarte, M. A. Rodkin, V. I. Sobolev; Catal. Today 41 (1998) 365.

136. V. P. Shiralkar, P. N. Joshi, M. J. Eapen, B. S. Rao; Zeolites 11 (1991) 511.

137. H. Kalipcilar, A. Culfaz; Cryst. Res. Technol. 36 (2001) 1197.

138. M. Padovan, G. Leofanti, M. Solari, E. Moretti; Zeolites 4 (1984) 295.

139. J. Warzywoda, R. D. Edelman, R. W. Thompson; Zeolites 11 (1991) 318.

140. G. Paparatto, E. Moretti, G. Leofanti, F. Gatti; J. Catal. 105 (1987) 227.

141. C. J. Jia, Y. Liu, W. Schmidt, A.-H. Lu, F. Schüth; J. Catal. 269 (2010) 71.

142. E. Yoda, A. Ootawa; Appl. Catal. A: Gen. 360 (2009) 66.

143. M. Pagliaro, M. Rossi; The Future of Glycerol: New Uses of a Versatile Raw Material; The Royal Society of Chemistry, Cambridge (2008).

144. Szabó Z., Kalló D.: Kontakt Katalízis, Akadémiai Kiadó, Budapest (1976).

145. US Patent 3997478 (1976).

146. US Patent 6153554 (2000).

147. C.H. Bartholomew, R.J. Farrauto, in Fundamentals of Industrial Catalytic Processes, John Wiley \& Sons, Ltd, Ch. 7.3.1, (2011).

148. M.J. Andrews, C. N. Pillai, Indian J. Chem. 16B (1978) 465.

149. B.W. Hoffer, J.A. Moulijn, Appl. Catal. A 352 (2009) 193.

150. N.-S. Chang, S. Aldrett, M.T. Holtzapple, R.R. Davison, Chem. Eng. Sci. 55 (2000) 5721.

151. I. Pogorelić, M. Filipan-Litvić, S. Merkaš, G. Ljubić, I. Cepanec, M. Litvić, J. Mol. Catal. A 274 (2007) 202.

152. K. Nishide, Y. Shigeta, K. Obata, T. Inoue, M. Node, Tetrahedron Lett. 37 (1996) 2271.

153. B. Chen, U. Dingerdissen, J.G.E. Krauter, H.G.J. Lansink Rotgerink, K. Möbus, D.J. Ostgard, P. Pansterc, T.H. Riermeier, S. Seebald, T. Tacke, H. Trauthwein, Appl. Catal. A 280 (2005) 17.

154. M. Raney, US Patent 1,628,190, United States Patent Office, 1927. 
155. J. Petró, A. Bóta, K. László, H. Neyer, E. Kálmán, I. Dódonyi; Appl. Catal. A: Gen. 190 (2000) 73.

156. R. J. Farrauto, C.H. Bartholomew; Fundamentals of Industrial Catalytic Processes, Blackie Academic and Professional Ltd, (1997).

157. P. Russ, 136-321 (1959)-C 1964 Nr. 27. 2275.

158. F. P. Dousek, J. Jansta, J. Riha; Collect. Czech. Chem. Commun. 31 (1966) 457.

159. D.A.S. 1175891 (1962).

160. F.P. 1549546 VARTA.

161. J.I. Macnab, R.B. Anderson, J. Catal. 29 (1973) 338.

162. J. Petró, L. Hegedűs, I. E. Sajó; Appl. Catal. A: Gen. 308 (2006) 50.

163. H. Remy, Lehrbuch der Anorganischen Chemie, II. Band, Akademische Verlag, Leipzig, (1954), p. 26.

164. F. Cavani, F. Trifiro, A. Vaccari, Catal. Today 11 (1991) 173.

165. E. Manasse; Att. Soc. Toscana Sci. Nat. 24 (1915) 92.

166. F. Winter: Hydrotalcite-based catalysts for the synthesis of Methyl Isobutyl Ketone Disszertáció, 2006; http://igitur-archive.library.uu.nl/dissertations/2006-0316-200316/c1.pdf; utolsó letöltés ideje: 2013. 10. 28.

167. W. Feitknecht; Helv. Chim. Acta 25 (1942) 131.

168. R. Allmann; Acta Cryst. B24 (1968) 972.

169. H. F. W. Taylor; Miner. Mag. 37 (1969) 338.

170. G. Centi, S. Perathoner; Micropor. Mesopor. Mat. 107 (2008) 3.

171. D. Tichit, B. Coq; Cattech 7 (2003) 206.

172. A. Vaccari; Catal. Today 41 (1998) 53.

173. D. G. Evans, R. C. T. Slade; Structure and Bonding 119 (2006) 1.

174. D. Tichit, O. Lorrent, B. Coq, F. Prinetto, G. Ghiotti; Micropor. Mesopor. Mat. 80 (2005) 213.

175. I. Pausch, H. Lohse, K. Schurmann, R. Allmann; Clays Clay Min. 34 (1986) 507.

176. Y. You, G .F. Vance, D. L. Sparks, J. Zhuang, Y. Jin; J. Environ. Qual. 32 (2003) 2046.

177. S. Miyata; Clays Clay Miner. 31 (1983) 305.

178. S. Miyata; Clays Clay Miner. 28 (1980) 50.

179. J. I. Di Cosimo, V. K. Díez, C. R. Apesteguía; Appl. Clay Sci. 13 (1998) 433.

180. F. Prinetto, G. Ghiotti, R. Durand, D. Tichit; J. Phys. Chem. B. 104 (2000) 11117.

181. Cwik A.: Szilárd bázis katalizált reakciók vizsgálata Ph.D. értekezés 2005.

182. A. Béres, I. Pálinkó, I. Kiricsi; React. Kin. Catal. Lett. 59 (1996) 47.

183. J. C. A. A. Roelofs, D. J. Lensveld, A. J. van Dillen, K. P. de Jong; J. Catal. 203 (2001) 184.

184. M. R. Kang, H. M. Lim, S. C. Lee, S.-H. Lee, K. J. Kim: Layered Double Hydroxide and its Anion Exchange Capacity; http://www.azom.com/article.aspx?ArticleID=2997; utolsó letöltés ideje: 2013. 10. 28.

185. F. Prinetto, G. Ghiotti, P. Graffin, D. Tichit; Micropor. Mesopor. Mat. 39 (2000) 229.

186. A. Béres, I. Pálinkó, I. Kiricsi, J. B. Nagy, Y. Kiyozimi, F. Mizukami; Appl. Catal. A: Gen. 182 (1999) 237. 
187. O. Lebedeva, D. Tichit, B.Coq; Appl. Catal. A: Gen. 183 (1999) 61.

188. F. Kooli, C. Depège, A. Ennaqadi, A. de Roy, J. P. Besse; Clays Clay Miner. 45 (1997) 92.

189. W. T. Reichle; Chemtech. 1 (1986) 58.

190. M. C. Richardson: Layered Double Hydroxid as anion- and cation- exchanging materials, Ph.D értekezés, 2007., University of North Texas, http://digital.library.unt.edu/ark:/67531/metadc3623/m2/1/high_res_d/dissertation.pdf; utolsó letöltés ideje: 2013. 10. 28.

191. J. L. Shumaker, C. Crofcheck, S. A. Tackett, E. Santillan-Jimenez, T. Morgan, Y. Ji, M. Crocker, T. J. Toops; Appl. Catal. B: Environ. 82 (2008) 120.

192. L. van der Ven, M. L. M. van Gemert, L. F. Batenburg, J. J. Keern, L. H. Gielgens, T. P. M. Koster, H. R. Fisher; Appl. Clay Sci. 17 (2000) 25.

193. J. Wang, A. G. Kalinichev, R. J. Kirkpatrick, X. Hou; Chem. Mater. 13 (2001) 145.

194. N. Bejoy; Resonance 6 (2001) 57.

195. J. H. Choy, S. Y. Kwak, J. S. Park, Y. J. Jeong; J. Mater. Chem. 11 (2001) 1671.

196. N. K. Lazaridis, T. A. Pandi, K. A. Matis; Ind. Eng. Chem. Res. 43 (2004) 2209.

197. S. Komarneni, N. Kozai, R. Roy; J. Mater. Chem. 8 (1998) 1329.

198. S. O’ Leary, D. O’ Hare, G. Seeley; Chem. Commun. 14 (2002) 1506.

199. A. Mastalir, Z. Kiraly; J. Catal. 220 (2003) 372.

200. A. E. Palomares, J. G. Prato, F. Marquez, A. Corma; Appl. Catal. B: Environ. 41 (2003) 3.

201. J. C. A. A. Roelofs, A. J. van Dillen, K. P. de Jong; Catal. Today 60 (2000) 297.

202. D. Tichit, M. H. Lhouty, A. Guida, B. Chiche, F. Figueras, A. Auroux, D. Bartalini, E.Garrone; J. Catal. 151 (1995) 50.

203. M. J. Climent, A. Corma, S. Iborra, A. Velty; Green Chem. 4 (2002) 474.

204. S. Miyata; Clays Clay Miner. 23 (1975) 369.

205. V.R.L. Constantino, T. J. Pinnavaia; Inorg. Chem. 34 (1995) 883.

206. S. Aisawa, Y. Ohnuma, K. Hirose, S. Takahashi, H. Hirahara, E. Narita; Appl. Clay Sci. 28 (2005) 137.

207. E. Narita, P. Kaviratra, T. J. Pinnavaia; Chem. Lett. 20 (1991) 805.

208. J. T. Kloprogge, L. Hickey, R. L. Frost; J. Solid State Chem. 177 (2004) 4047.

209. F. M. Labajos, V. Rives, M. A. Ulibarri; J. Mater. Sci. 27 (1992) 1546.

210. P. Fejes, J. B. Nagy, K. Kovács, Gy. Vankó; Appl. Catal. A: Gen. 145 (1996) 155.

211. G. Bellussi, A. Carati, M. G. Clerici, A. Esposito, Proc. of the $5^{\text {th }}$ Symposium on Scientific Bases for the Preparation of Heterogeneous Catalysts, Louvain la Neuve, Belgium (1990) 201.

212. G. Bellussi, G. Maddinelli, A. Carati, A. Gevasini, R. Millini, $9^{\text {th }}$ Int. Zeolite Conf., Montreal, Canada, 1992, Poster A-8.

213. H. G. Karge, H. K. Beyer; Stud. Surf. Sci. Catal. 69 (1991) 43.

214. E. D. Dimotakis, T. J. Pinnavaia; Inorg. Chem. 29 (1990) 2393.

215. K. S. W. Sing, D. H. Everett, R. A. W. Haul, L. Moscou, R. A. Pierotti, J. Rouquerol, T. Siemieniewska; Pure Appl. Chem. 57 (1985) 603.

216. S. Brunauer, P. H. Emmett, E. Teller; J. Am. Chem. Soc. 60 (1938) 309.

217. K. Foger, J. Sanders, D. Seddon; Zeolites 4 (1984) 337., PDF 37-0359, PCPDFWIN Version 2.3 JCPDS-ICDD 2002. 
218. B. Li, S. Li, Y. Wang, N. Li, X. Liu, B. Li; J. Solid State Chem. 178 (2005) 1030.

219. Z. Yaakob, M. N. S. Kumar, M.A. Ibrahim, W. R. W. Daud, A. A. H. Kadhum; Eur. J. Sci. Res. 28 (2009) 141.

220. X. Du, X. Su, Y. Wang, J. Li; Mater. Res. Bull. 44 (2009) 660.

221. G. Ervin, E. F. Osborn; J. Geol. 59 (1951) 381.

222. K. K. Kelley; U.S. Bur. Mines Bull. (1960) 584.

223. L. Candela, D. D. Perlmutter; Ind. Eng. Chem. Res. 31 (1992) 694.

224. J. Perić, R. Krstulović, M. Vućak; J. Therm. Anal. 46 (1996) 1339.

225. K. J. D. MacKenzie, J. Temuujin, K. Okada; Thermochim. Acta 327 (1999) 103.

226. B. Zhu, B. Fang, X. Li; Ceram. Int. 36 (2010) 2493.

227. S. Serena, M. A. Raso, M. A. Rodríguez, A. Caballero, T. J. Leo; Ceram. Int. 35 (2009) 3081.

228. Z. Yuan, L. Wang, J. Wang, S. Xia, P. Chen, Z. Hou, X. Zheng; Appl. Catal. B: Environ. 101 (2011) 431.

229. H.-Y. Zeng, Z. Feng, X. Deng, Y-Q Li; Fuel 87 (2008) 3071.

230. S. Sasaki, K. Fujino, Y. Takeuchi; Proc. Jpn. Acad. 55 (1979) 43.; PDF 71-1176, PCPDFWIN Version 2.3 JCPDS-ICDD 2002.

231. H.-W. Olfs, L. O. Torres-Dorante, R. Eckelt, H. Kosslick; Appl. Clay Sci. 43 (2009) 459.

232. M. A. Aramendía, V. Borau, C. Jiménez, J. M. Marinas, J. R. Ruiz, F. J. Urbano; Mater. Lett. 46 (2000) 309.

233. A. Geyer, W. Eysel; Mineral. Petrograph. Inst. Univ. Heidelberg, Germany ICDD Grant-inAid (1989); PDF 41-0254, PCPDFWIN Version 2.3 JCPDS-ICDD 2002.

234. W. T. Reichle, S. Y. Kang, D. S. Everhardt; J. Catal. 101 (1986) 352.

235. F. Rey, V. Fornes, J. M. Rojo; Faraday Trans. 88 (1992) 2233.

236. A. R. Auxilio, P. C. Andrews, P. C. Junk, L. Spiccia, D. Neumann, W. Raverty, N. Vanderhoek; Polyhedron 26 (2007) 3479.

237. J. M. R. Mercury, P. Pena, A. H. Aza; J. Am. Ceram. Soc. 89 (2006) 3728.

238. K. Parida, J. Das; J. Mol. Catal. Chem. 151 (2000) 185.

239. L. Pesic, S. Salipurovic, V. Markovic, D. Vucelic, W. Kagunya, W. Jones; J. Mater. Chem. 2 (1992) 1069.

240. R. L. Frost, S. J. Palmer, L.-M. Grand; J. Therm. Anal. Cal. 100 (2010) 981. 